\title{
Does Tax Risk Attenuate the Positive Association between Internal and External Information Quality?
}

\author{
Benjamin Osswald \\ University of Illinois at Urbana-Champaign \\ osswald@illinois.edu
}

July 21,2020

\begin{abstract}
This study examines whether tax risk attenuates the positive association between firms' internal information quality (IIQ) and external information quality (EIQ). Theoretically, higher IIQ allows managers to increase the quality of disclosures to external market participants, which improves EIQ. However, engaging in risky tax planning strategies discourages managers from disclosing information due to the risk of drawing attention from tax authorities (i.e., proprietary costs). I hypothesize and find that the association between IIQ and EIQ is fully attenuated for firms in the highest quintile of tax risk. A structural equation model and supplemental tests that account for business-related proprietary costs and uncertainty corroborate my findings. Overall, my results imply that firms with higher IIQ improve EIQ, on average. However, higher tax risk breaks down this link due to the proprietary costs of disclosing tax strategies to tax authorities.
\end{abstract}

Keywords: External information quality; financial reporting quality; information environment; internal information quality; proprietary costs; tax avoidance; tax planning; tax risk

JEL-Classifications: G30, H26, M41

This paper is based on my dissertation at the University of Wisconsin-Madison. I greatly appreciate the helpful guidance of my dissertation committee: Stacie Laplante (co-chair), Dan Lynch (co-chair), Dean Corbae, and Tom Linsmeier. For their helpful comments, I thank Harald Amberger, Ted (Seung Kyo) Ahn, Julia Ariel-Rohr, In Gyun Baek, Erik Beardsley, Christof Beuselinck, Tobias Bornemann, Amanda Carlson, Will Ciconte, Eva Eberhartinger, Diana Falsetta, Fabio Gaertner, Vanessa Gawehn, Michelle Hutchens, Zach King, Mayer Liang, Clay Partridge, Stefan Richter, Linette Rousseau, David Samuel, Rupert Sausgruber, Bridget Stomberg, Caren Sureth-Sloane, Logan Steele, Jacob Thornock, Dan Wangerin, Terry Warfield, Jeff Williams, Junwei Xia, Karla Zehms, and participants of the 2019 AAA/Deloitte/J. Michael Cook Doctoral Consortium, Arbeitskreis Quantitative Steuerlehre 2018 conference, and workshop participants at Indiana University, the TAF Young Researcher Workshop at Paderborn University, the University of Houston, the University of Illinois at Urbana-Champaign, and the University of WisconsinMadison. I also gratefully acknowledge the financial support of the George E. Frazer Scholarship. 


\section{Introduction}

This study investigates whether and to what extent tax risk attenuates the positive association between internal information quality (IIQ) and external information quality (EIQ). I define tax risk as the uncertainty of current period tax positions and operationalize it as the volatility of future tax payments (Guenther, Matsunaga, Williams 2017). ${ }^{1}$ I define IIQ as the ability of managers to collect and use data and knowledge efficiently within the organization, and EIQ as the quality of disclosures to external market participants (Gallemore and Labro 2015; Balakrishnan, Blouin, and Guay 2019). Theoretically, IIQ is an antecedent for EIQ and enables managers to increase the quality of external disclosures (Hemmer and Labro 2008; Dichev et al. 2013). Based on the rationale that risky tax planning discourages disclosure due to proprietary costs, I predict and find that tax risk breaks down the positive relation between IIQ and EIQ.

Taxes are a substantial part of firms' expenditures and higher internal information quality allows firms to implement tax planning strategies that lower effective tax rates (Gallemore and Labro 2015; McGuire et al. 2018; Laplante et al. 2019). However, recent literature suggests that complex tax planning strategies induce opacity in external financial statement disclosures that reduces EIQ (Frank, Lynch, and Rego 2009; Chen, Hepfer, Quinn, and Wilson 2018;

Balakrishnan et al. 2019; Ehinger, Lee, Stomberg, and Towery 2020). Managers can mitigate this opacity by disclosing private information about their tax positions but face proprietary costs because this information potentially attracts the attention of tax authorities and weakens the

\footnotetext{
${ }^{1}$ I measure tax risk as the volatility of future tax payments using the standard deviation of annual cash effective tax rates over the period $t+1$ to $t+5$ (Hutchens and Rego 2015; Guenther et al. 2017; Drake et al. 2019). This measure of tax risk captures the broadest spectrum of tax planning (e.g., temporary and permanent differences, aggressive strategies) whereas other measures, such as tax shelter scores or discretionary permanent book-tax differences, only capture specific types of transactions. I define tax planning as the level of effective tax rates. See section 2.2 for details.
} 
manager's position if there is an audit in subsequent years. Taken together, it is unclear whether firms disclose internal information to improve their EIQ when tax risk is high. ${ }^{2}$

Addressing this open question, I show that tax risk breaks down the link between IIQ and EIQ, as firms with higher IIQ have the ability to improve EIQ but may not wish to disclose proprietary information that could be used by tax authorities. Studying the interaction effects of IIQ, tax risk, and EIQ is important for understanding the interplay between two important strategic goals - high-quality financial reporting and effective management of tax strategies (Scholes and Wolfson 1992). Moreover, my findings speak to recent calls of academic literature to investigate the costs and benefits of firms' tax function more holistically (Hanlon and Heitzman 2010; Wilde and Wilson 2018).

Using a sample of U.S. public firms with financial statement data for 1993-2012, I test whether tax risk attenuates the positive association between IIQ and EIQ. Following recent literature, I use analysts' forecast error, analysts' dispersion, and idiosyncratic return volatility as proxies for EIQ ( Chen et al. 2018a; Balakrishnan et al. 2019). ${ }^{3}$ I use earnings announcement speed, management forecast accuracy, and an indicator variable for the lack of material weaknesses as proxies for IIQ (Gallemore and Labro 2015; McGuire et al. 2018). Consistent with theoretical predictions, I find a positive and significant association between IIQ and EIQ, suggesting that higher IIQ indeed allows managers to provide decision useful disclosures that increase EIQ, on average.

\footnotetext{
${ }^{2}$ Figure 1 depicts the theoretically predicted relation among IIQ, tax risk, and EIQ.

${ }^{3}$ My sample ends in 2012 but uses financial statement data until 2016 to compute the standard deviation of annual cash effective tax rates over the period $t+1$ to $t+5$. I use 2016 as the final sample year because it represents the last full year prior to enactment of the Tax Cuts and Jobs Act (TCJA) of 2017.
} 
In my main analysis that includes an interaction term between tax risk and IIQ, I find that tax risk fully attenuates the association between IIQ and EIQ for the highest quintile of tax risk. ${ }^{4}$ These results indicate that the proprietary costs of tax risk outweigh the benefits of increasing external information quality even though firms have the necessary internal information systems in place to generate this information. I also document that the attenuating effect of tax risk on the association between IIQ and EIQ is more pronounced when analysts forecast tax expense and when firms face IRS scrutiny. Managers appear to respond to expectations set by analyst forecasts and higher IRS scrutiny by decreasing EIQ due to the proprietary costs of risky tax planning strategies (Ehinger et al. 2020).

In additional analyses, I use a structural equation model (SEM) framework to capture the underlying constructs of IIQ and EIQ using factor analysis. Moreover, this framework allows me to investigate the interactive effect of IIQ, EIQ, and tax risk holistically. Results of these analyses confirm that tax risk is a moderator to the association between IIQ and EIQ and that my proposed theoretical model in Figure 1 provides the best model fit to explain the relations among IIQ, tax risk, and EIQ compared to alternative models. Combined, my results suggest that IIQ is positively associated with EIQ but that this association is attenuated by tax risk.

I corroborate my primary findings using the adoption of Financial Accounting Standards Board Interpretation No. 48 (FIN 48) as an exogenous shock to proprietary costs of claiming risky tax positions and alternative measure of tax risk. Specifically, I find that the association between IIQ and EIQ is attenuated for firms affected by FIN 48 (with positive unrecognized tax benefits balance) after the adoption of the standard. This test improves the internal validity of my results. Additional analyses suggest that decreased tax accrual quality is one driver for the

\footnotetext{
${ }^{4}$ My research design includes a comprehensive set of controls for the level of tax planning, operations-related volatility and proprietary costs of disclosure, and firm risk. Section 3.2 provides further details.
} 
observed attenuating impact of tax risk on EIQ. Furthermore, my results indicate that managers do not increase tax-related disclosure in response to tax risk when internal information quality is high.

In supplemental tests, I address concerns that differences in market participants' ability to predict future earnings or tax expense, which could lead to a mechanical relation between IIQ and EIQ, drive my results. I bifurcate my sample into firms for which analysts under- or overestimate tax expense or earnings and continue to find an attenuating impact of tax risk on the relation between IIQ and EIQ. This indicates that the documented association is not driven by differences in market participants' forecasts. Additional "horse race" tests that include an interaction of the level of tax planning and IIQ provide evidence that tax risk, not the level of tax planning, is the attenuating effect on the association between IIQ and EIQ. Inferences regarding the attenuating impact of tax risk are also unchanged when I interact IIQ with a proxy for proprietary costs, abnormal profitability, which addresses the concerns that tax risk is correlated with business-related proprietary costs. Finally, my inferences about the impact of tax risk remain unchanged when I add an interaction of IIQ with business-related uncertainty measures.

My findings contribute to several streams of research. First, they add to the literature on the factors that affect the corporate information environment (Hemmer and Labro 2008; Chen, Martin, Roychowdhury, Wang, and Billet 2018). My study identifies tax risk as an important factor that breaks down the link between IIQ and EIQ (Dichev et al. 2013; Heinle et al. 2018; Samuels 2020). The findings provide evidence that tax risk generates proprietary costs that limit managers' willingness to convey internal information to external market participants (Verrecchia 1983; Heinle et al. 2018). ${ }^{5}$ Second, the comprehensive approach of my study complements and

\footnotetext{
${ }^{5}$ See Appendix B for an overview of the incremental contribution of this paper to the literature.
} 
extends prior literature that explores the relation between tax planning strategies and the information environment. Prior literature focuses on the level of tax planning and its effect on the information environment (Chen et al. 2018a; Balakrishnan et al. 2019). My analyses provide evidence that tax risk and not the level of tax planning decreases external information quality.

Finally, this study jointly investigates IIQ, tax risk, and EIQ and therefore responds to the call from Wilde and Wilson (2018) to examine the costs of tax risk and benefits of tax planning more holistically. Studying these interaction effects is important to understand the direct and indirect costs of tax planning that shape managers' decisions and outcomes for investors (Scholes and Wolfson 1992; Hanlon and Heitzman 2010; Robinson and Schmidt 2013). Specifically, the finding that EIQ does not increase in IIQ if firms implement tax planning strategies with high tax risk suggests high levels of tax risk generate indirect costs to market participants through decreased financial reporting quality. This finding adds to prior literature that suggests a strictly positive association between IIQ and tax planning without considering their joint effect on EIQ. My study should also be of interest to analysts, investors, and regulators in understanding the effects of government efforts to curtail aggressive tax planning strategies on a firm's tax risk and EIQ (OECD 2015).

\section{Theoretical Background and Hypothesis Development}

\subsection{Internal and External Information Environment}

The information environment is critical for the efficiency of a firm's operations because a high-quality information environment facilitates internal decisions, increases firm value, and mitigates information asymmetries to its shareholders and potential investors (Coase 1937). The information environment of the firm consists of both an internal (collection and use of data within a firm) and external information environment (disclosure of information to external 
market participants resulting in higher financial reporting quality). Prior literature suggests that these two dimensions are interrelated and that managers consider both dimensions jointly (Hemmer and Labro 2008; Dichev et al. 2013; Hemmer and Labro 2019; Labro et al. 2020).

High internal information quality is important for internal decisions. IIQ reduces information asymmetries within firms and increases capital budgeting as well as investment efficiency (Heitzman and Huang 2019). The positive effect of IIQ on investment efficiency is more pronounced in environments with higher organizational complexity because IIQ is crucial for resource allocation (Bushman et al. 2004). Internal information quality also allows managers to provide higher quality external information and disclosure of estimates to market participants, such as voluntarily disclosed earnings and risk forecasts (Hemmer and Labro 2008; Ittner and Michels 2017; Samuels 2020). ${ }^{6}$ Theoretically, higher IIQ enables managers to convey more useful information to market participants, resulting in a positive association between IIQ and EIQ (for an analytical model, see Hemmer and Labro 2008). Initially, I formally test this relation.

\subsection{The Effect of Tax Risk on the Association between IIQ and EIQ}

Internal information quality also allows firms to implement tax planning strategies. IIQ facilitates tax planning by providing better estimates of taxable income needed to engage in tax planning (Gallemore and Labro 2015; Laplante et al. 2019). For example, firms with higher IIQ can better coordinate among various business units and set up transfer pricing schemes that lower their effective tax rates without disclosing other proprietary information (Mills, Erickson, and Maydew 1998; Robinson, Sikes, and Weaver 2010). Higher quality internal information also

\footnotetext{
${ }^{6}$ Shroff (2017) and Cheng et al. (2018) provide additional evidence that external reporting requirements affects information environments that managers rely upon for decision making.
} 
increases managers' ability to defend tax positions because it allows them to provide stronger supporting documentation to regulators, which reduces tax risk (Hamilton and Stekelberg 2017).

Despite the positive effects of tax planning through increased after-tax cash flows, tax planning also induces tax and non-tax costs (Scholes and Wolfson 1992). These costs comprise implementation, agency, and outcome costs (Wilde and Wilson 2018). For example, implementation and outcome costs include investments in information systems, coordination costs among business units, and potential penalties for tax planning strategies as a result of tax audits (Lewellen and Robinson 2014; Bauer 2016; Krenn 2017). Outcome costs include organizational complexity and lower corporate transparency (Chen et al. 2018a; Li, Ma, Omer, and Sun 2018; Balakrishnan et al. 2019; McGuire, Neuman, and Rice 2019). ${ }^{7}$ These outcome costs materialize when market participants cannot reliably assess the economic implications of greater complexity induced by tax planning. Consequently, corporate transparency decreases, resulting in tax-related outcome costs to external market participants (Chen et al. 2018a).

Managers can offset these outcome costs by increasing tax-related disclosure but face a trade-off. While additional disclosure provides information to market participants that mitigates outcome costs, it might contain proprietary information that also increases regulatory scrutiny of aggressive tax positions (Robinson and Schmidt 2013; Bozanic, Hoopes, Thornock, and Williams 2017; Inger et al. 2018). Specifically, the IRS can use additional disclosures in the enforcement process to complement private information (Hoopes, Mescall, and Pittman 2012; Fox and Wilson 2019). Proprietary costs also arise because competitors might use any proprietary information contained in public disclosures (Verrecchia 1983). Hence, managers are

\footnotetext{
${ }^{7}$ Lower transparency may be due to agency conflicts. However, the findings of Balakrishnan et al. (2019, p. 58) indicate that agency conflicts with managers do not explain the documented negative relation between transparency and tax planning. Nonetheless, I control for institutional ownership in all specifications to mitigate concerns that agency conflicts drive my results.
} 
potentially unwilling to disclose information about tax planning activities to external market participants due to proprietary costs.

Tax risk is distinct from tax planning because firms can obtain benefits from tax planning with varying degrees of uncertainty. A firm's tax planning strategies can alter the level and the volatility in tax payments over time (Guenther et al. 2017; Drake et al. 2019). Consistent with the traditional view in classical finance, risk refers to the dispersion of potential outcomes from an investment and reflects the degree of uncertainty about the future. Dispersion in those potential cash tax savings is tax risk (Amberger 2017; Guenther et al. 2017; Drake et al. 2019; Hutchens, Rego, and Williams 2019). Consequently, tax risk captures fluctuations in tax payments due to tax positions claimed in one period but reversed later upon audit by tax authorities or government interventions (e.g., see Appendix C for the case of Forrest Labs) (Neuman, Omer, and Schmidt 2020). Concurrent literature also documsents that volatile tax payments are associated with equity investors' valuation and firm risk (Drake et al. 2019; Donohoe, Gale, and Mayberry 2020). For my purposes, managers implement a tax planning strategy in the current year and market participants realize whether the strategy leads to volatile tax payments in subsequent periods as it leads to volatile future tax payments (see Figure 2). ${ }^{8}$

Overall, prior literature indicates that IIQ enables tax planning strategies and increases the firm's ability to defend these strategies to tax authorities through better compliance systems (i.e., reduces tax risk). Internal information quality also allows firms to disclose related information to market participants (Hemmer and Labro 2008). However, if tax planning strategies result in heightened tax risk, managers could be unwilling to increase the level or

\footnotetext{
${ }^{8}$ Prior literature indicates that market participants may be confused because it is difficult for them to separate taxrelated issues from growth estimates (Drucker 2010; Beardsley 2016; Bratten, Glaeson, Larocque and Mills 2017; Koutney 2019).
} 
quality of external information due to proprietary costs, making it more difficult for market

participants to predict economic outcomes. Stated differently, firms with higher IIQ convey more information to market participants, on average. However, tax risk attenuates this relation. Based on this argument, I state the following hypothesis in the alternative form:

H1: Tax risk attenuates the positive association between internal and external information quality.

\section{Research Design and Sample}

\subsection{Variable Measurement}

\section{Internal Information Quality}

I use four publicly observable proxies for IIQ that capture different aspects of IIQ (Gallemore and Labro 2015; Laplante et al. 2019; McGuire et al. 2018; Heitzman and Huang 2019). First, earnings announcement speed (IIQ_EAS) equals the average number of days between the end of the quarter and the earnings announcement date, divided by 365 and multiplied by negative one. ${ }^{9}$ Firms with a high-quality accounting system are capable of quickly integrating information from different parts of the organization so they can close their books faster. For example, a Textron's 2003 news release about the adoption of a new performance management software explains that it worked with Ernst \& Young to implement a financial consolidation and reporting module. The implementation of the system resulted in a shortening of its financial closing process by four days. ${ }^{10}$ Second, I adjust each firm's earnings announcement speed by the same period's earnings announcement speed for the portfolio of firms in the same quintile of total assets (Size) and the same industry and year (IIQ_EAS_FF17).

\footnotetext{
${ }^{9}$ In untabulated tests, I also use the number of days between the end of the fiscal year and the earnings announcement date. Results are consistent in both sign and significance.

${ }^{10}$ See new release, available at:

https://www.pcworld.idg.com.au/article/25973/textron_propels_transformation_global_financial_reporting_using_h yperion_software/ (last access: July 20, 2020).
} 
I sort Size and industry independently, and base industry on the 17 industries defined by Fama and French (1997) because similar-sized firms in the same industry are expected to have similar internal capabilities to convey information to market participants. A positive value of IIQ_EAS_FF17 implies that the firm has a higher IIQ compared to its industry peers. To the extent that size and industry capture a substantial portion of organizational complexity, this measure captures variation within a group of firms with similar internal capabilities to manage this complexity. ${ }^{11}$

Third, management forecast accuracy $\left(I I Q \_M F A\right)$ equals the absolute value of management's last available estimate of earnings per share before fiscal year-end minus the firm's actual earnings per share, divided by the stock price at the end of the year and multiplied by negative one. ${ }^{12} I I Q \_M F A$ is a proxy for IIQ because inaccuracies in managers' internal information cause errors in management forecasts and accruals (Cassar and Gibson 2008). Finally, I use the absence of material weaknesses in controls (IIQ_No_ICW) as my fourth proxy because internal control weaknesses indicate poor IIQ (Bauer 2016; Cheng et al. 2018; McGuire et al. 2019). IIQ_No_ICW is an indicator variable equal to zero if the firm reported a SOX Section 404 material weakness in the current fiscal year, and one otherwise. I construct each proxy so that higher values indicate higher IIQ.

\section{External Information Quality}

I use three different measures to capture the level of external information quality. I define EIQ as the quality of disclosures to external market participants. I use absolute analysts' forecast

\footnotetext{
${ }^{11} I I Q \_E A S \_F F 17$ also holds constant the IIQ level when comparing firms with high vs. low tax risk. For example, consider a relatively small and a relatively large firm in the same industry that do not differ in their earnings announcement speed. When using IIQ_EAS, the proxy attributes the same level of IIQ and hence the same capabilities to manage tax planning and organizational complexity. The IIQ_EAS_FF17 accounts for fundamental differences in size- and industry-related characteristics.

${ }^{12}$ Ideally, I would like to isolate the accuracy of tax expense component of management forecast. However, I/B/E/S guidance does currently not provide a sufficient sample size to integrate this measure in my analyses.
} 
errors (AFError) and dispersion in analysts' forecasts (AFDisp) as proxies for the information content that market participants obtain from analysts' forecasts (Chen et al. 2018a; Balakrishnan et al. 2019). Based on the rationale that tax risk results in less disclosure, analysts are less able to accurately forecast earnings. This manifests in the absolute errors of forecasts and the disagreement among analysts. Consistent with prior literature, I define AFError as the absolute value of the difference between the mean of analyst forecasts issued immediately before the fiscal year-end and the actual earnings for that fiscal year, scaled by the price at the end of the previous year (Gu and Wu 2003). I define AFDisp as the standard deviation of the analysts' forecasts issued immediately before the fiscal year-end (Chen et al. 2018a; Balakrishnan et al. 2019). Krishnaswami and Subramaniam (1993) and Roulstone (2003) provide evidence that analysts forecast dispersion captures disagreement among analysts indicating a lack of available information about a firm. I do not investigate the effect of tax risk on analysts' tax expense forecasts because these two measures are mechanically related and investors require information in information about after-tax cashflows to value firms. ${ }^{13}$

To capture usefulness of information provided by managers to a broader range of market participants, I use idiosyncratic return volatility, IDVOL. Idiosyncratic stock returns primarily reflect the incorporation of private information into stock prices through informed trading, rather than through the incorporation of public information into stock prices (Roll 1988; Armstrong, Balakrishnan, and Cohen 2012). Therefore, idiosyncratic return volatility provides a summary measure of a firm's private information flows reflecting the usefulness of information provided by managers to market participants (Armstrong et al. 2012; Chen et al. 2018a). If managers disclose less information due to proprietary costs associated with tax risk, market participants

\footnotetext{
${ }^{13}$ In untabulated tests, inferences do not change when using tax expense analyst forecast error as dependent variable.
} 
perceive the provided information less useful, which increases idiosyncratic return volatility. I measure IDVOL as the five-year average of standard deviation of residuals from firm-specific regressions of daily returns on daily values of the Fama-French (1993) three factors plus the momentum factor over the years $t+1$ to $t+5$ (Carhartt 1997; Campbell and Taksler 2003; Chen et al. 2018a). For ease of interpretation, I multiply EIQ_Error, and EIQ_Disp by (-1), and EIQ_IDVOL by (-100), so an increase in these proxies corresponds to an increase in EIQ.

\section{Tax Risk and Tax Planning}

I follow recent tax risk literature and measure Tax Risk as the future 5-year $(t+1$ to $t+$ 5) standard deviation of industry-adjusted annual cash effective tax rates (Guenther et al. 2017; Drake et al. 2019). ${ }^{14}$ I construct the Tax Risk measure in three steps. First, I calculate annual cash effective tax rates $\left(C A S H \_E T R\right)$ defined as cash taxes paid for the year scaled by pre-tax income and censor $C A S H E T R$ to be between zero and one. ${ }^{15}$ Second, I adjust each firm's $C A S H$ ETR by the same period's mean CASH ETR for the portfolio of firms in the same quintile of total assets (Size) and the same industry (TA_CASH_1). I sort Size and industry independently, and base industry on the 17 industries defined by Fama and French (1997). ${ }^{16}$ The resulting measure, $T A \_C A S H \_1$, captures cross-sectional variation in firms' total tax planning (including temporary and permanent book-tax differences) and benchmarks a given firm's tax aggressiveness relative to that of similar-sized firms in the same industry. A positive value of $T A \_C A S H \_1$ implies a

\footnotetext{
${ }^{14}$ The standard deviation of industry-adjusted effective tax rates accounts for the volatility and the level of tax planning. Jacob and Schütt (2019) provide evidence that market participants take into account the level and uncertainty of tax planning jointly. This approach follows a similar rationale as the coefficient of the variation that is normalized by the underlying mean cash effective tax rates. Results are similar when using the standard deviation of unadjusted CASH ETR and the coefficient of variation.

${ }^{15}$ Balakrishnan et al. (2019) do not adjust the denominator by special items when calculating their industry- and size-adjusted measures. In untabulated tests, I modify the denominator for special items and results are consistent in both sign and significance.

${ }^{16}$ I use Fama-French 17 industry classification to be consistent with the IIQ_EAS_FF17 measure. Inferences of my results are unchanged when I re-estimate my specifications using Fama-French 48 industry classification.
} 
higher level of tax planning (lower effective tax rate) compared to industry peers. Third, I calculate Tax Risk as the five-year standard deviation (period $t+1$ to $t+5$ ) of TA_CASH_l. This 5-year measure links managers' current tax planning strategies to volatility in future cash tax payments. ${ }^{17}$

\subsection{Research Design}

To analyze the relation between IIQ and EIQ, I estimate the following OLS regression model:

$$
\begin{aligned}
\text { EI }_{i, t}= & \alpha_{0}+\beta_{1} \text { II }_{i, t}+\sum_{k} \beta_{k} \text { Controls }_{i, t}+\sum_{j} \beta_{j} \text { Industry Fixed Effects }_{i}+ \\
& \sum_{l} \beta_{l} \text { Year Fixed Effects }{ }_{t}+\varepsilon_{i, t}
\end{aligned}
$$

where $E I Q$ is one of the three adjusted measures for EIQ, analyst forecast error (EIQ_Error), analyst dispersion (EIQ_Disp), and idiosyncratic return volatility $\left(E I Q \_I D V O L\right)$. I use four proxies for IIQ (IIQ_EAS, IIQ_EAS_FF17, IIQ_MFA, IIQ_No_ICW). A positive coefficient, $\beta_{1}$, indicates a positive association between IIQ and EIQ.

I include control variables that prior research identifies as determinants of the information environment. To control for an expected positive relation between firm size and the information environment, I include Size, the log of total assets. To control for firms' capital structure, I include Leverage, the ratio of long-term debt to total assets (Chen et al. 2018a; Chen et al. 2018b). Prior literature documents that loss firms have on average lower earnings quality and higher levels of information asymmetry (Hwang, Jan, and Basu 1996). Thus, I also include an indicator variable, Loss, equal to one if a firm reports a net operating loss $\mathrm{n}$ the current year and zero otherwise. I include Foreign Income because investors and analysts value foreign earnings differentially relative to domestic earnings (Bodnar and Weintrop 1997; Duru and Reeb 2002). To control for a relation between firms' growth opportunities and EIQ, I include market-to-book

\footnotetext{
${ }^{17}$ For robustness tests, I construct Tax Risk_GAAP using GAAP ETR and repeat the same steps as for Tax Risk.
} 
ratio $(M T B)$ equal to the ratio of the market value of assets to the book value of assets, and firm age (Age), the log of the difference between the first year when the firm appears in Compustat and the current year. I include the log of the number of analysts following the firm (Analyst Following) to capture the quantity of firms' information production (Weber 2009; Beardsley 2016; Bratten et al. 2017).

To control for organizational complexity, I use Bushman et al.’s (2004) revenue-based Herfindahl-Hirschman geographic concentration index because geographically diversified firms are more opaque in their disclosures (Bushman et al. 2004; Chen et al. 2018a). I include a measure for operating volatility because prior literature documents a negative association between sales volatility and accrual quality which negatively affects the precision of forecasts (Dechow and Dichev 2002). To control for operating volatility, I use the standard deviation of annual sales computed over the future five years (Std Dev. of Sales) and the standard deviation of the ratio of annual pretax book income to lagged total assets over the future five years (Std Dev. of $P T B I)$. To control for operational changes and related uncertainty, I add an indicator variable, Restructure, equal to one if the firm reports a restructuring expense during years $t+1$ to $t+5$, and zero otherwise. Restructuring captures fundamental changes in a firm's organization, strategy, systems, or operations and results in uncertainty affecting its information environment (Lin and Yang 2006). I include the percentage of institutional investors (Institutional Ownership) to account for potential agency conflicts and differences that affect managers decisions to collect and disclose information to market participants (Berger and Hann 2007; Balakrishnan et al. 2019).

Proprietary costs are an important factor that affects managers' disclosure of internal information to market participants. Managers face proprietary costs of disclosure if the revelation 
of business activities that earn high abnormal profits attracts more competition and, hence, reduces the abnormal profits. Managers tend to withhold the information of segments with relatively high abnormal segment profits when they face proprietary costs (Berger and Hann 2007). I use industry-size adjusted return on assets $\left(I_{-} R O A\right)$ as a measure of abnormal segment profits (Berger and Hann 2007; Heinle et al. 2018). I measure $I \_R O A$ at the firm level and base the industry adjustment on the firm's primary Fama French 17 classification, and the size adjustment on the quintile of the firm within the industry. This approach is consistent with the industry adjusted IIQ_EAS_FF17 and Tax Risk measures.

Recent literature documents a negative association between tax planning and future firm risk. To control for this association, I include the future volatility of stock returns $\left(S D \_R e t\right)$. This measure is computed as the standard deviation of the 12 monthly returns in the fiscal year immediately following year $t$ used to calculate the five-year volatility of cash tax payments (Tax Risk) (Guenther et al. 2017; Drake et al. 2019; Hutchens et al. 2019). Finally, I include year and industry-fixed effects to account for year shocks and time-invariant industry characteristics. Unless indicated otherwise, I winsorize all continuous variables at the $1^{\text {st }}$ and $99^{\text {th }}$ percentiles to mitigate the effect of outliers. I estimate heteroscedasticity-robust standard errors clustered by firm to account for serial correlation in the data (Petersen 2009; Gow, Ormazabal, and Taylor 2010). Appendix A provides detailed definitions for all variables. ${ }^{18}$

To test whether tax risk attenuates the positive association between IIQ and EIQ (Hypothesis 1), I modify Equation (1) to include Tax Risk and its interaction with IIQ: $E I Q_{i, t}=\alpha_{0}+\beta_{1} I I Q_{i, t}+\beta_{2}$ Tax Risk $_{i, t+1-5}+\beta_{3} I_{I Q_{i, t}} *$ Tax Risk $_{i, t+1-5}+\sum_{k} \beta_{k}$ Controls $_{i, t}+$

\footnotetext{
${ }^{18}$ I also modify Equation (1) and use a changes model that removes firm-specific fixed effects and potential confounding effects from time-invariant variables. See Appendix A.1 for details.
} 


$$
\sum_{j} \beta_{j} \text { Industry Fixed Effects }{ }_{i}+\sum_{l} \beta_{l} \text { Year Fixed Effects } s_{t}+\varepsilon_{i, t}
$$

where IIQ and EIQ are as previously defined, and Tax Risk is the future 5-year standard deviation of annual cash effective tax rates. I expect a positive (negative) coefficient on $\beta_{1}\left(\beta_{2}\right)$. Consistent with the prediction of an attenuating effect of tax risk in Hypothesis 1, I predict a negative coefficient on $\beta_{3}{ }^{19}$ The interaction of $I I Q$ and Tax Risk allows me to compare different levels of tax risk while holding the level of internal information quality constant.

\subsection{Sample Selection}

I obtain data from the Compustat and CRSP, IBES and Audit Analytics databases. Table 1 presents the sample selection procedure. The sample begins after December 15, 1992, which is the effective date of adoption of FASB Statement of Financial Accounting Standards No. 109. I include all publicly traded, U.S.-based corporations with necessary data to compute the respective information environment and control variables. My sample ends in 2012 but uses financial statement data until 2016 to compute the standard deviation of annual cash effective tax rates over the period $t+1$ to $t+5$. I require positive $P I$ in year $t$ and cumulative positive $P I$ over the five-year window. In addition to requiring non-missing data to compute each variable, I also require firm-years to have positive values for beginning total assets, ending total assets, and pretax book income. I exclude REITs (SIC code 6798) because they are not typically subject to entity-level taxation (Guenther et al. 2017; Balakrishnan et al. 2019). ${ }^{20}$

To estimate Equations (1) and (2), I constrain my sample to firms for which I can

\footnotetext{
${ }^{19}$ I also include $T A \_C A S H \_3$ which is the 3 -year average of $T A \_C A S H \_l$ to control for the level of prior three years' tax planning strategy that affects the external information environment (Chen et al. 2018a; Balakrishnan et al. 2019).

${ }^{20}$ I do not exclude financial institutions because I am interested in the role of tax risk on external information quality. Although financial firms are subject to a different regulatory environment and face different tax planning strategies, I argue that my industry- and size-adjusted measures account for these differences. Inferences are unchanged when I run Equations (2) for industrial and financial firms separately. 
compute tax planning measures, obtain analysts' forecast error estimates, and compute control variables. My sample comprises 20,680 firm-year observations. The sample size drops to 17,465 firm-year observations for regressions that involve analyst dispersion metrics, and 20,564 for regressions that involve idiosyncratic return volatility. The sample size also contracts for regressions using $I I Q \_M F A$ and $I I Q \_N o \_I C W$ because management discloses forecasts voluntarily and data on material weaknesses (SOX Section 404) are only available after 2002. < Insert Table 1 here >

\section{Results}

\subsection{Descriptive Statistics}

Table 2 presents the descriptive statistics for the sample. Overall, the descriptive statistics are comparable to descriptive statistics of prior literature (Gallemore and Labro 2015; Guenther et al. 2017; McGuire et al. 2018; Balakrishnan et al. 2019; Drake et al. 2019). The means (medians) of EIQ_Error, EIQ_Disp, and EIQ_IDVOL are -0.008, -0.313, and -2.226 (-0.005, -0.162 , and -2.026), respectively. ${ }^{21}$ Consistent with prior literature, the absolute value of the mean of EIQ_Disp is higher than for EIQ_Error (Balakrishnan et al. 2019). The mean (median) of Tax Risk is $0.155(0.121)$, and the standard deviation is $12.0 \%$ which is consistent with the measures used in Guenther et al. (2017) and Drake et al. (2019). The mean (median) of CASH ETR and GAAP ETR and is $28.6 \%$ (27.0\%) and 34.3\% (35.5\%), respectively. As in Balakrishnan et al. (2019), the means of both industry-size adjusted measures, $T A \_C A S H \_3$ and $T A \_G A A P \_3$, are below zero (-0.033 and -0.057 , respectively) and cross-sectional variation is of similar

\footnotetext{
${ }^{21}$ Consistent with prior literature I winsorize EIQ_Error and EIQ_Disp at the $99^{\text {th }}$ percentile level because the variables are bound at 0 . I also winsorize at the $95^{\text {th }}$ percentile level to alleviate concerns that my results are driven by outliers and inferences remain unchanged.
} 
magnitude as for GAAP ETR and CASH ETR. ${ }^{22}$

< Insert Table 2 here >

Table 3 presents univariate Pearson (below the diagonal) and Spearman (above the diagonal) correlations. As expected, there is a positive correlation between EIQ and IIQ proxies (except for $\left.I I Q \_n o \_I C W\right)(\mathrm{p}<0.01) .{ }^{23}$ Tax Risk and the three measures for external informational quality are negatively correlated (all $\mathrm{p}<0.01$ ). The correlation between Tax Risk and tax planning measures is negative, indicating that firms with high levels of tax planning use strategies that are persistent (Guenther et al. 2017; Drake et al. 2019). ${ }^{24}$ Tax Risk is negatively correlated with business-related proprietary costs measure, $I \_R O A(-0.053, \mathrm{p}<0.01)$. The correlation between Tax Risk and SD_Ret is $0.092(\mathrm{p}<0.01)$ indicating a positive correlation between the two volatility factors. All other correlations are generally consistent with prior research (Gallemore and Labro 2015; Balakrishnan et al. 2019). ${ }^{25}$

< Insert Table 3 here >

\subsection{Association between IIQ and EIQ}

I predict a positive association between IIQ and EIQ. Table 4 presents results for OLS regressions based on Equation (1). Columns (1) to (2) present the results for EIQ_Error as the dependent variable, column (3) and (4) for EIQ_Disp, and columns (5) and (6) for EIQ_IDVOL. Coefficients on all $I I Q$ proxies are positive and significant $(\mathrm{p}<0.07)$ in all specifications.

\footnotetext{
${ }^{22}$ Note that the means of the $T A \_C A S H \_1$ and $T A \_C A S H \_3$ measures are not zero because the measure uses all firms with available ETR data in the Compustat database to estimate three-year ETRs in the size-industry bins. In my final sample, however, firm-year observations that do not allow me to compute all control variables are not included. Distributions of the variables are similar to prior literature.

${ }^{23}$ Consistent with Chen, Hepfer, Quinn, and Wilson (2015), the correlation of analyst forecast measures (EIQ_AF_Error and EIQ_AF_Disp) and idiosyncratic return volatility $\left(E I Q \_I D V O L\right)$ is negative.

${ }^{24}$ The magnitude of the correlation is similar to Guenther et al. (2017) that uses the 5-year volatility of CASH_ETR_1. Note that Guenther et al. (2017, Fn.9) construct the industry-adjusted cash effective tax rates differently from Balakrishnan et al. (2019).

25 To further provide comfort with the proxies, I replicate the studies by Gallemore and Labro (2015) and Balakrishnan et al. (2019) and find results consistent in both sign and significance.
} 
Consistent with theoretical predictions, this suggests that IIQ is positively associated with EIQ. ${ }^{26}$ Firms with high internal information quality disclose information that is relevant to market participants resulting in more precise predictions of future economic outcomes.

For control variables, I find that EIQ_Error and EIQ_Disp decrease by the size of the firm (Size), debt (Leverage), and complexity and volatility of business operations (Std Dev. of Sales, $I \_R O A, S D \_R e t$, and $S t d$. Dev. of PTBI). MTB is positively associated with all dependent variables. These determinants and their respective magnitudes are consistent with prior research (Chen et al. 2018a; Balakrishnan et al. 2019). From an economic significance perspective, a onestandard-deviation increase in IIQ_EAS is associated with an increase in EIQ_Error (EIQ_Disp) [EIQ_IDVOL] of 8.5 percent ( 6.5 percent) $[5.4$ percent $] .{ }^{27}$ Combined, these results indicate a positive association between IIQ and EIQ.

\section{$<$ Insert Table 4 here >}

\subsection{The Attenuating Effect of Tax Risk on the Association between IIQ and EIQ}

Hypothesis 1 predicts an attenuating effect of tax risk on the association between IIQ and EIQ. To test Hypothesis 1, I use Equation (2) that includes an interaction term of Tax Risk and a proxy for IIQ. This allows me to compare different levels of tax risk while holding constant the level of internal information quality. ${ }^{28}$ For this and subsequent tests, I use EIQ_Error, EIQ_Disp, and $E I Q \_I D V O L$ as dependent variables and IIQ_EAS as a proxy for IIQ. ${ }^{29}$

\footnotetext{
${ }^{26}$ Table A.1, panel A presents additional results for $I I Q \_M F A$ and $I I Q \_N o \_I C W$. Table A.1, panel B presents the results for a changes model. The changes model indicates significant coefficients for ten out of twelve specifications at the 10 percent or better significance level, except for $I I Q_{-} N o_{-} I C W$. This provides additional support for a positive association between IIQ and EIQ. One reason for the less pronounced results for IIQ_No_ICW is the time lag of internal control weaknesses (not only one period) affecting other financial metrics (Kim, Song, and Zhang 2011).

${ }^{27}$ To calculate this, I calculate standardized coefficients using the formula beta*[std. dev (X_i $) / \operatorname{std}$. dev (Y)].

${ }^{28}$ In untabulated tests, I re-run the regression for observations below and above the median of IIQ_EAS. Inferences are unchanged.

${ }^{29}$ In untabulated tests, I estimate Equation (2) using $I I Q \_F F 17, I I Q \_M F A$, and $I I Q \_N o \_I C W$. Inferences remain unchanged.
} 
Table 5, panel A presents the results for a continuous measure and an indicator variable of Tax Risk. The indicator variable (Tax RiskQ5) takes the value of one if a firm-year observation of Tax Risk in the top sample quintile, and zero otherwise, allowing me to investigate whether the effect of tax risk is more pronounced for firms with the highest level of tax risk. ${ }^{30}$ Columns (1), (3) and (5) present my results for the continuous measure of Tax Risk and columns (2), (4), and (6) for the indicator variables for each EIQ proxy. The coefficients of IIQ_EAS (Tax Risk) are positive (negative) and significant $(\mathrm{p}<0.01)$. The coefficients on the interaction of $I I Q \_E A S^{*}$ Tax Risk are negative and significant (all $\left.\mathrm{p}<0.05\right)$. F-tests indicate high tax risk fully attenuates the positive coefficient on IIQ_EAS $\left(I I Q \_E A S+I I Q \_E A S * T a x\right.$ RiskQ5 = 0). Importantly, the specifications include the firm's average industry- and size-adjusted effective cash tax rate in years $t-2$ to $\mathrm{t}\left(\mathrm{TA} \mathrm{C}_{-} \mathrm{CASH} 3 \mathrm{~B}\right)$ to alleviate concerns that the documented associations are affected by the firm's level of tax planning that market participants can observe in year $t^{31}$

The results above provide initial evidence that tax risk attenuates the positive association between IIQ and EIQ. However, prior literature provides evidence that tax-related analyst forecasts provide additional information to market participants and benchmarks for managers (Beardsley 2016; Bratten et al. 2017; Mauler 2019). Therefore, managers might use discretion about tax expenses to meet analyst forecasts. I re-estimate Equation (2) in Table 5, panel B and

\footnotetext{
${ }^{30}$ One concern about this approach is that the distributions of IIQ differ between firms with high and low Tax Risk. In untabulated plots, I find similar distributions of IIQ_EAS for high and low levels of Tax Risk.

${ }^{31}$ The tests above use the standard deviation of industry- and size-adjusted future cash effective tax rates $\left(T A \_C A S H_{-} l\right)$ as a proxy for tax risk. In untabulated tests, I address concerns that market participants use the unadjusted $C A S H E T R$ as a reference point to account for volatility. I re-estimate all specifications using the standard deviation of the firm's future annual cash effective tax rates $(C A S H E T R)$ over the period $t+1$ to $t+5$ and inferences remain unchanged. Furthermore, I find similar results using industry- and size adjusted GAAP ETR instead of CASH ETR measures to compute the tax risk measure. This addresses the concern that firm's GAAP ETR is a more important tax metric to management than cash taxes paid (Graham, Hanlon, Shevlin, and Shroff 2014; Armstrong et al. 2015; Flagmeier, Müller, and Sureth-Sloane 2017).
} 
bifurcate my sample into firm-year observations for which analysts forecast tax expenses (columns 1, 3, and 5) and do not forecast tax expenses (columns 2, 4, and 6). While I continue to find negative and significant coefficients on IIQ_EAS*Tax RiskQ5 for observations for which tax expense forecasts are available, the respective coefficients for observations without tax expense coverage are insignificant $(\mathrm{p}>0.10)$. The differences in the coefficients of IIQ_EAS*Tax Risk are significant for EIQ_Error and EIQ_Disp (p < 0.01). Combined, these results provide evidence that tax risk attenuates the association between internal and external information quality and that this effect is more pronounced when analysts forecast tax expense. This suggests that managers appear to respond to expectations set by analyst forecasts by providing less external disclosures to market participants presumably due to the proprietary costs of risky tax planning strategies.

Concurrent research provides evidence that firms also face tax proprietary costs due to an increased likelihood of near-continuous IRS audit, discouraging managers from voluntarily disclosing tax-related information (Ehinger et al. 2020). To this end, I create a continuous measure of the likelihood that a firm is part of the Internal Revenue Service' Coordinated Industry Case (CIC) program (CIC Score) to operationalize higher tax proprietary costs (Ayers, Seidman, and Towery 2019). I bifurcate my sample into firms that have a CIC Score below (above) the sample median reflecting low (high) tax proprietary costs. I re-estimate Equation (2) in Table 5, panel C for firm-year observations that face low (columns 1,3, and 5) and high tax proprietary costs (columns 2, 4, and 6). I also include Tax Reporting Complexity to account for complexity related to a firm's tax reporting (Bratten et al. 2017; Ehinger et al. 2020). The negative and significant coefficients on IIQ_EAS*Tax RiskQ5 for sub-samples of firms with a high likelihood of continuous IRS audit (all $\mathrm{p}<0.05)$ indicate that the effect of tax risk is more 
pronounced for firms that face high tax proprietary costs. This result suggests that managers decrease tax-related disclosure due to tax proprietary costs.

$$
<\text { Insert Table } 5 \text { here > }
$$

\subsection{Structural Equation Modeling}

I next employ a two-step structural equation modeling (SEM) that allows me to examine the associations among IIQ, EIQ and tax risk. I use this approach because the underlying concepts of IIQ and EIQ are difficult to capture and SEM uses a factor analysis of several variables for the underlying constructs (i.e., IIQ and EIQ). SEM also allows me to explore the interactions among the constructs by comparing the model fits. In the first step, I estimate the factor loadings of IIQ and EIQ. To this end, I submit IIQ_EAS,IIQ_MFA, and IIQ_No_ICW to a factor analysis. Figure 3, panel A presents the factor loadings for IIQ ranging from 0.09 to 0.51 producing a factor (eigenvalue $=2.16$ ) that explains 54.04 percent of the variance. Next, I submit EIQ_Error and EIQ_IDVOL, and EIQ_Disp and EIQ_IDVOL to a factor analysis, creating EIQ_Factor_I and EIQ_Factor_2, respectively. ${ }^{32}$ The factor analyses produce factors (eigenvalue $=2.00$ and 2.01) that explain 66.75 and 67.16 percent of the variances, respectively.

In the second step, I use the factor loadings in a regression framework and explore the role of tax risk using different model specifications as prior literature does not provide clear predictions about the interplay of IIQ, tax risk, and EIQ. To explore the role of tax risk, I follow Kline (2015) and use four metrics to evaluate the goodness-of-fit of my models including the Comparative Fit Index (CFI), Root Mean Square Error of Approximation (RMSEA),

\footnotetext{
${ }^{32}$ I do not create one single factor including all three EIQ proxies because both analy st-based measures are highly collinear.
} 
Standardized Root Mean Square Residual (SRMR), and overall chi-square. ${ }^{33}$ In my first model, I use Equation (2) (equivalent to Hayes Model 1 (Hayes 2018)) and integrate the factor loadings for IIQ and EIQ_Factor_2. Figure 3, panel B provides the regression results and the goodnessof-fit statistics. Regression results from the structural equation model are consistent with my findings using OLS regressions. The coefficient on IIQ_EAS*Tax RiskQ5 is negative and significant $(\mathrm{p}<0.01)$ indicating that tax risk fully attenuates the positive relationship between internal and external information quality. ${ }^{34}$ Goodness-of-fit statistics indicate a very good fit of this model with values of $1.00,0.00$, and 0.00 , for CFI, RMSEA, and SRMR respectively.

Next, I modify the SEM model and add paths between IIQ and Tax Risk as well as Tax Risk and EIQ (Hayes Model 74, depicted in Figure 3, panel C). Goodness-of-fit statistics (CFI of 0.917, RMSEA of 0.038, and SRMR of 0.004) indicate a lower explanatory power of the model compared to the initial model. Results of these analyses confirm that tax risk is a moderator to the association between IIQ and EIQ and that my proposed theoretical model in Figure 1 is more explanatory compared to alternative models in explaining the relations among IIQ, tax risk, and EIQ.

\section{$<$ Insert Figure 3 here >}

\subsection{FIN 48 as a Shock to Tax Risk}

I use the adoption of FASB Interpretation No. 48, Accounting for Uncertainty in Income Taxes (FIN 48/ASC 740-10), as a shock and alternative measure of tax risk. Prior literature provides evidence that FIN 48 raised proprietary costs of claiming risky or uncertain tax

\footnotetext{
${ }^{33}$ Hooper, Coughlan, and Mullen (2008) provide a summary of traditional rules of thumb for fit statistics. CFI above 0.95 is considered a good fit. RMSEA below 0.10 and 0.06 represents reasonable fit and very well fit, respectively. SRMR values below 0.08 are acceptable.

${ }^{34}$ My results indicate a full attenuation when using standardized values obtained from model-fitted variances and when I standardize variables by using the formula beta*[std. dev (X_i)/std. dev (Y)].
} 
positions. Mandated tax disclosure increases in the post FIN 48 environment as there is a heightened focus on tax uncertainty which increases the likelihood of having to disclose costly tax information. This might exacerbate the incentive to obfuscate internal information quality. Consequently, this setting allows me to investigate how a plausibly exogenous increase to proprietary costs of claiming risky tax positions affects the association between IIQ and EIQ (Gupta, Mills, and Towery 2014). The adoption of FIN 48 also provides an alternative measure of tax risk that does not rely on the volatility of future ETRs.

FIN 48 is a financial accounting disclosure regulation effective for fiscal years beginning after December 15, 2006 that requires firms to record liabilities for uncertain tax benefits that do not meet a more likely than not threshold of being sustained upon audit (Blouin and Robinson 2014). FIN 48 was enacted to address concerns about the lack of comparability and transparency in accounting for uncertain tax positions (Gupta et al. 2014). I limit the analysis to three years before and three years after the adoption of FIN 48 (fiscal years: 2004-2009) to reduce the likelihood of capturing a random, non-FIN 48 related event. I follow Gupta et al. (2014) and classify firms with a positive unrecognized tax benefits (UTB) opening balance in fiscal year 2007 as affected by FIN 48. I define fiscal years from 2004 to $2006(P O S T=0)$ as the pre-FIN 48 and fiscal years from 2007 to 2009 as post-FIN48 period $(P O S T=1)$.

In Table 6, I use a sample of firms that have an opening UTB balance in 2007 and hence are affected by FIN 48. I modify Equation (2) by replacing Tax Risk with POST. Columns (1), (3), and (5) include all firms that have an opening balance (UTB_2007). For these firms, I find negative and significant coefficients for $I I Q \_E A S^{*} P O S T(\mathrm{p}<0.05)$ in two out of three specifications for firms that experience a shock to tax risk. The negative coefficients for $I I Q \_E A S * P O S T$ provide some evidence that FIN 48 increased tax risk that is associated with a 
decrease in EIQ. In columns (2), (4), and (6), I use a sample of firms with the UTB/total assets ratio in 2007 in the highest quintile $(U T B Q 5) .{ }^{35}$ Again, the coefficients for $I I Q \_E A S * P O S T$ are in two out of three specifications negative. Untabulated tests indicate that the coefficients are not significantly different $(\mathrm{p}>0.35)$ for the highest quintile firms compared to the sample of all firms with an opening balance in 2007. Combined, the results suggest that the association between IIQ and EIQ is attenuated for firms affected by FIN 48 after the adoption of the standard.

\section{< Insert Table 6 here >}

\subsection{How Tax Risk affects the Association between IIQ and EIQ}

To examine how tax risk affects the association between IIQ and EIQ, I examine tax accrual quality and tax-related disclosure in 10-K filings, tax footnote, and MD\&A. Consistent with Choudhary, Koester, and Shevlin (2016), I define tax accrual quality as the mapping of tax accruals into their related cash flows. Prior literature provides evidence that tax accrual quality is an important criterion of high-quality financial reporting shaping the external information environment (Choudhary et al. 2016; Goh et al. 2016). Theoretically, high IIQ reduces management estimation error of tax expense because management appears more likely to accurately estimate taxable income. Based on this rationale, I expect a positive association between IIQ and tax accrual quality. However, in the presence of high tax risk, it is more difficult for managers to accurately estimate the tax accrual and/or manage accruals (Brazel and Dang 2008). To test these conjectures, I replace the dependent variable in Equation (2) with the tax accrual quality measure (TaxAQ) developed by Choudhary et al. (2016).

\footnotetext{
${ }^{35}$ The mean of the UTB/total assets ratio is 0.011 , which is consistent with the mean documented in Gupta et al. (2014).
} 
Table 7, panel A presents the results. ${ }^{36}$ Consistent with my initial tests, the coefficients on $I I Q \_E A S$ are positive and significant $(\mathrm{p}<0.03$, one-tailed). This indicates that higher IIQ increases the informativeness of tax expense as a signal of firms' estimated taxable income (i.e., higher tax accrual quality). For the continuous variable Tax Risk (column 1), I find a negative but insignificant coefficient on Tax Risk ( $\mathrm{p}>0.25$, one-tailed) and a negative and significant interaction of IIQ_EAS*Tax Risk (p <0.08, one-tailed). In column (2), I replace the continuous variable of Tax Risk with an indicator variable taking the value of one for firm-year observations with tax risk in the top sample quintile (Tax RiskQ5). The coefficients on Tax RiskQ5 and the interaction of IIQ_EASQ5*Tax Risk are negative and significant (p $<0.09$, one-tailed). A negative coefficient on Tax Risk (Tax RiskQ5) indicates that more ex-ante uncertainty in tax planning outcomes makes it harder for firms to estimate their tax accrual accurately. The negative interaction term suggests that tax risk attenuates the positive association between IIQ and tax accrual quality. These findings remain unchanged when I use an industry- and sizeadjusted measure of tax accrual quality TaxAQ_FF17 (columns (3) and (4)).

I next investigate whether tax risk attenuates the association between IIQ and the volume of tax-related disclosure. Prior literature documents that managers use tax-related disclosure in financial statements to convey information to market participants (Beardsley 2016; Bratten et al. 2017; Mauler 2019). However, managers of firms with risky tax planning have incentives to conceal information from the tax authority by disclosing less information in financial statements (Inger et al. 2018). I use data derived from searches of 10-K filings, tax footnotes, and Management Discussion and Analysis (MD\&A) for specific references to taxes (e.g., 'Income Taxes,' 'Tax') that record the word count related to taxes. Collectively, these measures represent

\footnotetext{
${ }^{36}$ The sample size is reduced substantially due to the eight-year window required to calculate $\operatorname{Tax} A Q$.
} 
the level of tax-related disclosure (Kubick, Lynch, Mayberry, and Omer 2016; Inger et al. 2018). To this end, I replace the dependent variable of Equation (2) with the natural logarithm of word counts in the 10-K filings (Log10KWord), footnote (LogFNWord), and MD\&A (LogMDAWord), respectively. I present results in Table 7, panel B. The negative and significant coefficients $(\mathrm{p}<$ 0.01 ) in columns (1) and (2) on $I I Q \_E A S$ indicate that mangers with high internal information quality disclose relatively less tax-related information in 10-K filings. The coefficients on Tax Risk and Tax RiskQ5 and their respective interactions are positive but insignificant ( $\mathrm{p}>0.38)$. Managers appear to not change tax footnote disclosure in the presence of tax risk. The positive coefficients on $T A \_C A S H \_3(\mathrm{p}<0.01)$ indicate a positive association between the level, rather than the riskiness, of tax planning and tax-related disclosure in 10-K filings (Balakrishnan et al. 2019).

In columns (3) and (4), I use word counts in the tax footnote (LogFNWord) as proxy for disclosure. Again, I find a negative and significant coefficient on $I I Q \_E A S$ but insignificant coefficients on Tax Risk and Tax RiskQ5 and their respective interactions ( $>$ >0.10). The results in columns (5) and (6) provide similar inferences. Overall, the results in panel B indicate that managers with high IIQ disclose less tax-related information. However, the findings do not provide evidence that managers increase the volume of tax-specific disclosure in the presence of tax risk. ${ }^{37}$ Untabulated tests indicate that managers of firms with high IIQ appear to disclose more in case of increased economic uncertainty and the level of tax planning but do not increase disclosure in response to increased tax risk.

< Insert Table 7 here >

\footnotetext{
${ }^{37}$ In untabulated tests, I re-estimate all specifications described in this section adding an interaction term of $T A \_C A S H \_3$ and $I I Q \_E A S$. Inferences are unchanged.
} 


\subsection{Supplemental Tests}

To assess the robustness of my findings, I conduct several additional tests. First, I address concerns that differences in market participants' ability to predict future earnings or tax expense, which could lead to a mechanical relation between IIQ and EIQ, drive my results. Prior literature documents that analysts may under-estimate tax expenses for firms with low effective tax rates (Mauler 2019). If firms with low tax rates also engage in more risky tax planning strategies, my results could be driven by these firms and reflect a mechanical effect of tax risk on the relation between IIQ and EIQ. To mitigate this concern, I bifurcate the sample in Table 8, panel A into firm-year observations where analysts under- $\left(T A X E X P_{-} E r<0\right)$ [columns 1 and 3] or overestimate tax expenses (TAXEXP_Er $>0$ ) [columns 2 and 4]. As above, the coefficients on the interaction terms of IIQ_EAS*TaxRiskQ5 are negative and significant in three $(\mathrm{p}<0.10)$ out of the four specifications. This indicates that the attenuating effect of tax risk is not driven by differences in market participants' tax expense forecasts.

In panel $\mathrm{B}$, I repeat the tests bifurcating earnings forecast errors $\left(A F_{-} E R\right)$ instead of tax expense forecasts. Inferences are unchanged indicating that my findings are not driven by differences in market participants' earnings forecasts. These results provide support that tax risk attenuates the positive association between IIQ and EIQ independently of whether analysts under- or overestimates earnings or tax expense.

Second, I conduct a "horse race" test between the level of tax planning and tax risk to alleviate concerns that the level of tax planning and not the volatility of future cash tax payments drive my results. I modify Equation (2) and add the interaction of IIQ_EAS and the level of prior years' tax planning level (TA_CASH_3). ${ }^{38}$ Table 8 , panel C presents the results. The results in

\footnotetext{
${ }^{38}$ I use the industry-size adjusted level of tax planning of years $t-2$ to $t$ to proxy for market participants' expectations of future levels of tax planning in year $t$ (Bratten et al. 2017).
} 
Columns (1) to (3) indicate a negative coefficient on the interaction term of IIQ_EAS*Tax RiskQ5 (p < 0.05). Importantly, the interaction of IIQ_EAS*TA_CASH_3_Q5 is insignificant (p $>0.10)$. These results indicate that tax risk and not the level of tax planning is the driving attenuating factor of the association between IIQ and EIQ.

Third, I conduct a second set of "horse race" between tax risk and business-related proprietary costs and volatility to mitigate concerns that tax risk is correlated with these factors and drive my results. To this end, I modify Equation (2) and add the interaction of IIQ_EAS and I_ROAQ5 and Std. Dev. of SalesQ5 (volatility of sales in $t+1$ to $t+5$ ), respectively. Table 8, panel $\mathrm{D}$ and $\mathrm{E}$ present the results. Again, the coefficients on the interaction of IIQ_EAS*Tax RiskQ5 are negative and significant in all six specifications $(\mathrm{p}<0.05) .{ }^{39}$ These results provide support that tax risk is an important attenuating factor in addition to business-related proprietary costs and volatility. ${ }^{40}$ Overall, the results of Tables 5 to 8 provide support for Hypothesis 1 , indicating that higher internal information quality is associated with higher external information quality, but that a high level of tax risk fully attenuates this relation.

< Insert Table 8 here >

\section{Conclusion}

This paper investigates whether and to what extent tax risk attenuates the association between internal and external information quality. I find that the positive association between IIQ and EIQ is fully attenuated for firms with high tax risk. Additional analyses indicate that tax risk decreases EIQ through decreased tax accrual quality and that managers do not change the

\footnotetext{
${ }^{39}$ Importantly, the coefficient on the interaction of IIQ_EAS*Std. Dev. of SalesQ5 is positive and significant ( $<$ < 0.05). This is consistent with theoretical predictions that IIQ increases the capability of firms to convey information about business-related uncertainty.

${ }^{40}$ In untabulated tests, I add an indicator variable to reflect if managers have an incentive to increase earnings in order to meet consensus forecasts (threshold of \$0.01). Inferences remain unchanged.
} 
volume of tax-related disclosure as a response to tax risk. Combined, the results imply that IIQ increases EIQ, on average, but proprietary costs resulting from tax risk attenuate this association.

These findings add to the literature that investigates the relation between the internal and external information environment by documenting that tax risk is an important moderator for this association (Hemmer and Labro 2008; Chen et al. 2018b). This paper also adds to the literature that explores the relation between tax planning and the information environment (Gallemore and Labro 2015 Balakrishnan et al. 2019) by providing evidence that tax risk and not the level of tax planning is the primary attenuating factor of the association between IIQ and EIQ.

Finally, this study responds to the call from Wilde and Wilson (2018) to examine the costs and benefits of tax planning and resulting tax risk holistically. The findings provide evidence that tax risk shapes managers' decisions to disclose information to market participants and hence results in indirect costs for investors. Therefore, I believe that my results are of interest to academic literature, firms' stakeholder, and regulators in determining whether firms respond differently to government efforts to curtail aggressive tax planning strategies.

Despite the analyses and supplemental tests, this study has several limitations. Although I control for several uncertainty factors and managerial incentives, I cannot completely rule out correlated omitted variables that affect the association between IIQ and EIQ. Additionally, although I use an established measure for tax risk, the current version of the paper does not directly link changes in tax risk to underlying events that lead to higher tax payments. To strengthen inferences, I plan to extract specific tax-related disclosure such as changes in transfer pricing strategies or IRS settlements. My current analyses only include the volume of disclosed information. However, prior literature provides evidence that managers vary tax-related disclosure volume and quality to conceal information from the tax authority (Law and Mills 
2015; Inger et al. 2018). In the next version of the paper, I plan to investigate the readability of tax-related disclosures to speak to the quality of tax-related disclosures rather than the volume. 


\section{References}

Amberger, H. 2017. Tax Uncertainty and Dividend Payouts. Working Paper, WU - Vienna University of Economics and Business.

Armstrong, C. S., K. Balakrishnan, and D. Cohen. 2012. Corporate governance and the information environment: Evidence from state antitakeover laws. Journal of Accounting and Economics 53 (1): 185-204.

Ayers, B., J. Seidman, and E. Towery. 2019. Tax reporting behavior under audit certainty. Contemporary Accounting Research 36 (1): 326-358.

Balakrishnan, K., J. L. Blouin, and W. Guay. 2019. Tax Aggressiveness and Corporate Transparency. The Accounting Review 94 (1): 45-69.

Bauer, A. M. 2016. Tax Avoidance and the Implications of Weak Internal Controls. Contemporary Accounting Research 33 (2): 449-486.

Beardsley, E. L. 2016. Interim Tax Reporting Accuracy. Doctoral Thesis, Texas A\&M University.

Berger, P. G., and R. Hann. 2007. Segment Profitability and the Proprietary and Agency Costs of Disclosure. The Accounting Review 82 (4): 869-906.

Blouin, J. L., and L. A. Robinson. 2014. Insights from Academic Participation in the FAF's Initial PIR: The PIR of FIN 48. Accounting Horizons 28 (3): 479-500.

Bodnar, G. M., and J. Weintrop. 1997. The valuation of the foreign income of US multinational firms: A growth opportunities perspective. Journal of Accounting and Economics 24 (1): 69-97.

Bratten, B., C. A. Gleason, S. A. Larocque, and L. F. Mills. 2017. Forecasting Taxes: New Evidence from Analysts. The Accounting Review 92 (3): 1-29.

Brazel, J.F., and L. Dang. 2008. The Effect of ERP System Implementations on the Management of Earnings and Earnings Release Dates. Journal of Information Systems 22(2): 1-21.

Bushman, R. M., Q. Chen, E. Engel, and A. Smith. 2004. Financial accounting information, organizational complexity and corporate governance systems. Journal of Accounting and Economics 37: 167-201.

Campbell, J. L., M. Cecchini, A. M. Cianci, A. C. Ehinger, and E. M. Werner. 2019. Tax-related mandatory risk factor disclosures, future profitability, and stock returns. Review of Accounting Studies 24 (1): 264-308.

Campbell, J. Y., and G. N. Taksler. 2003. Equity Volatility and Corporate Bond Yields. The Journal of Finance 58: 2321-2350.

Carhart, M. M. 1997. On persistence in mutual fund performance. Journal of Finance 52 (1): 5782.

Cassar, G., B. Gibson. 2008. Budgets, internal reports, and manager forecast accuracy. Contemporary Accounting Research 25 (3): 707-737.

Chen, C.-W., B. Hepfer, P. Quinn, and R. Wilson. 2015. Tax-Motivated Income Shifting and the Information Environment. Working Paper, University of Iowa.

Chen, C.-W., B. Hepfer, P. Quinn, and R. Wilson. 2018 (2018a). The effect of income shifting on the information environment: Evidence from two-stage least squares and SFAS 131. Review of Accounting Studies 23 (3): 958-1004.

Chen, C., X. Martin, S. Roychowdhury, X. Wang, and M. T. Billet. 2018 (2018b). Clarity Begins at Home: Internal Information Asymmetry and External Communication Quality. The Accounting Review 93 (1): 71-101. 
Cheng, Q., B.W. Goh, and J.B. Kim. 2018. Internal Control and Operational Efficiency. Contemporary Accounting Research. 35 (2): 1102-1139.

Coase, R. 1937. The nature of the firm. Economica 4: 386-405.

Dechow, P., and I. Dichev. 2002. The quality of accruals and earnings: The role of accrual estimation errors. The Accounting Review 77 (s-1): 35-59.

Dichev, I. D., J. R. Graham, C. R. Harvey, S. Rajgopal. 2013.Earnings quality: Evidence from the field. Journal of Accounting and Economics 56: 1-33.

Donohoe, M. P., B. T. Gale, and M. A. Mayberry. 2020. The market reaction to corporate tax planning advice regulation. Working Paper, University of Illinois, University of Washington, and University of Florida.

Drake, K. D., S. J. Lusch, and J. Stekelberg. 2019. Does Tax Risk Affect Investor Valuation of Tax Avoidance? Journal of Accounting, Auditing, and Finance 34 (1): 151-176.

Drucker, J. 2010. U.S. companies dodge $\$ 60$ billion in taxes with global odyssey. Bloomberg (May 13). Available at: https://www.bloomberg.com/news/articles/2010-05-13/americancompanies-dodge-60-billion-in-taxes-even-tea-party-would-condemn (last access May 20, 2020).

Duru, A., and D. Reeb. 2002. International diversification and analysts' forecast accuracy and bias. The Accounting Review 77 (2): 415-433.

Ehinger, A. C., J. A. Lee, B. Stomberg, and E. Towery. 2020. The Trade-Off between Reporting Complexity and Proprietary Costs in Voluntary Disclosure Decisions: Evidence from Voluntary Tax Disclosures. Working Paper, Florida State University, University of Georgia, and Indiana University.

Fama, E. F., and K. R. French. 1993. Common risk factors in the returns on stocks and bonds. Journal of Financial Economics 33: 3-56.

Fama, E. F., French, K. R., 1997. Industry costs of equity. Journal of Financial Economics 43: 153- 193.

Flagmeier, V., J. Müller, and C. Sureth-Sloane. 2017. When do managers highlight their effective tax rate? arqus Discussion Paper No. 214.

Fox, Z. D., and R. Wilson. 2019. Double Trouble: An analysis of IRS attention and financial reporting. Working Paper, University of Oregon.

Frank, M. M., L. Lynch, and S. Rego. 2009. Tax reporting aggressiveness and its relation to aggressive financial reporting. The Accounting Review 84 (2): 467-496.

Gallemore, J., and E. Labro. 2015. The importance of the internal information environment for tax avoidance. Journal of Accounting and Economics 60: 149-167.

Goh, B. W., J. Lee, C. Y. Lim, and T. Shevlin. 2016. The Effect of Corporate Tax Avoidance on the Cost of Equity. The Accounting Review 91 (6): 1647-1670.

Gow, I. D., G. Ormazabal, and D. J. Taylor. 2010. Correcting for cross-sectional and time-series dependence in accounting research. The Accounting Review 85 (2): 483-512.

Graham, J. R., M. Hanlon, T. Shevlin, and N. Shroff. 2014. Incentives for tax planning and avoidance: Evidence from the field. The Accounting Review 89 (3): 991-1023.

Gu, Z., and J. S. Wu. 2003. Earnings skewness and analyst forecast bias. Journal of Accounting and Economics 35: 5-29.

Gupta, S., L. F. Mills, and E. M. Towery. 2014. The Effect of Mandatory Financial Statement Disclosures of Tax Uncertainty on Tax Reporting and Collections: The Case of FIN 48 and Multistate Tax Avoidance. The Journal of the American Taxation Association 36 (2): 203-229. 
Guenther, D. A., S. R. Matsunaga, and B. M. Williams. 2017. Is Tax Avoidance related to Firm Risk? The Accounting Review 92 (1): 115-136.

Hamilton. R. and J. Stekelberg. 2017. The Effect of High-Quality Information Technology on Corporate Tax Avoidance and Tax Risk. Journal of Information Systems 31 (2): 83-106.

Hanlon, M., and S. Heitzman. 2010. A review of tax research. Journal of Accounting and Economics 31: 405-440.

Hayes, A. F. 2018. Introduction to Mediation, Moderation, and Conditional Process Analysis - A Regression-Based Approach (2nd ed.). New York, NY: Guilford Press.

Heinle, M., D. Samuels, and D. Taylor. 2018. Proprietary Costs and Disclosure Substitution: Theory and Empirical Evidence. Working Paper, University of Pennsylvania and MIT.

Heitzman, S., and M. Huang. 2019. Internal Information and Investment Sensitivities to Market Value and Cash Flow. Contemporary Accounting Research, forthcoming.

Hemmer, T., and E. Labro. 2008. On the Optimal Relation between the Properties of Managerial and Financial Reporting Systems. Journal of Accounting Research 45 (5): 1209-1240.

Hooper, D., J. Coughlan, and M. R. Mullen. 2008. Structural Equation Modelling: Guidelines for determining model fit. Electronic Journal of Business Research Methods 6 (1): 53-60.

Hoopes, J. L., D. Mescall, and J. A. Pittman. 2012. Do IRS Audits Deter Corporate Tax Avoidance? The Accounting Review 87 (5): 1603 - 1639.

Hutchens, M., and S. O. Rego. 2015. Does Greater Tax Risk Lead to Increased Firm Risk? Working Paper, University of Illinois and Indiana University.

Hutchens, M., S. O. Rego, and B. Williams. 2019. Tax Avoidance, Uncertainty, and Firm Risk. Working Paper, University of Illinois and Indiana University.

Hwang, L., C. L. Jan, and S. Basu. 1996. Loss Firms and Analysts; Earnings Forecast Errors. The Journal of Financial Statement Analysis (Winter 1996): 18-30.

Inger, K. K., M. D. Meckfessel, M. Zhou, and W. Fan. 2018. An Examination of the Impact of Tax Avoidance on the Readability of Tax Footnotes. The Journal of the American Taxation Association 40 (1): 1-29.

Ittner, C. D., and J. Michels. 2017. Risk-based forecasting and planning and management earnings forecasts. Review of Accounting Studies 22: 1005-1047.

Jacob, M., and H. H. Schütt. 2019. Firm Valuation and the Uncertainty of Future Tax Avoidance. European Accounting Review: 1-27.

Kim, J.-B., B.Y. Song, and L. Zhang. 2011. Internal Control Weakness and Bank Loan Contracting: Evidence from SOX Section 404 Disclosures. The Accounting Review 86 (4): 1157-1188.

Kline, R. B. 2015. Principles and practice of structural equation modeling (4th ed.). New York, NY: Guilford Press.

Koutney, C. 2019. Do analysts improve on managers' voluntary ETR forecasts? Working Paper. George Mason University.

Krenn, P. 2017. The Impact of Taxation on Managerial Incentives and Compensation. Doctoral Thesis, University of Graz.

Krishnaswami, S., and V. Subramaniam. 1993. Information asymmetry, valuation, and the corporate spin-off decision. Journal of Financial Economics 53 (1): 73-112.

Kubick, T. R., D. P. Lynch, M. A. Mayberry, and T. C. Omer. 2016. The effects of regulatory scrutiny on tax avoidance: An examination of SEC comment letters. The Accounting Review 91 (6): 1751-1780.

Laplante, S.K., D. P. Lynch, and M. E. Vernon. 2019. The Association between Internal 
Information Quality and State Tax Planning. Working Paper, University of WisconsinMadison.

Law, K. K. F., and L. F. Mills. 2015. Taxes and Financial Constraints: Evidence from Linguistic Cues. Journal of Accounting Research 53 (4): 777-819.

Li, C., M. Ma, T.C. Omer, K. Sun. 2018. How Does Tax Avoidance Affect Corporate Transparency? Working Paper, Singapore Management University, American University, University of Nebraska-Lincoln, and Tsinghua University.

Lin, B., and R. Yang. 2006. The effect of repeat restructuring charges on analysts' forecast revisions and accuracy. Review of Quantitative Finance and Accounting 27: 267-283.

Mauler, L. M. 2019. The Effect of Analysts' Disaggregated Forecasts in Investors and Managers: Evidence Using Pre-Tax Forecasts. The Accounting Review 94 (3): 279-302.

McGuire, S. T., S. G. Rane, and C. D. Weaver. 2018. Internal information quality and taxmotivated income shifting. The Journal of the American Taxation Association 40 (2): 2544.

Mills, L., M.M. Erickson, and E.L. Maydew. 1998. Investments in Tax Planning. Journal of American Taxation Association 20 (1): 1-20.

Neuman, S. S., T. C. Omer, and A. P. Schmidt. 2020. Assessing Tax Risk: Practitioner Perspectives. Contemporary Accounting Research, forthcoming.

OECD. 2015. OECD/G20 Base Erosion and Profit Shifting Project - Explanatory Statement.

Petersen, M.A. 2009. Estimating standard errors in finance panel data sets: Comparing approaches. The Review of Financial Studies 22 (1): 435-480.

Robinson, L. A, and A. P. Schmidt. 2013. Firm and Investor Responses to Uncertain Benefit Disclosure Requirements. Journal of American Taxation Association 35 (2): 85-120.

Robinson, J. R., S. A. Sikes, and C. D. Weaver. 2010. Performance Measurement of Corporate Tax Departments. The Accounting Review 85 (3): 1035-1064.

Roll, R., 1988. R². Journal of Finance 25: 541-566.

Roulstone, D. T. 2003. Analyst following and market liquidity. Contemporary Accounting Research 20 (3): 551-578.

Roychowdhury, S., N. Shroff, and R. S. Verdi. 2019. The Effects of Financial Reporting and Disclosure on Corporate Investment: A Review. Journal of Accounting and Economics, forthcoming.

Samuels, D. 2020. Government procurement and changes in firm transparency. The Accounting Review, forthcoming.

Scholes, M. S., and M. A. Wolfson. 1992. Taxes and Business Strategy: A Planning Approach. Prentice-Hall, Inc., Engelwood Cliffs, NJ.

Verrecchia, R. E. 1983. Discretionary disclosure. Journal of Accounting and Economics 5: 365380.

Weber, D. 2009. Do analysts and investors fully appreciate the implication of book-tax differences for future earnings? Contemporary Accounting Research 26 (4): 1175-1206.

Wilde, J. H. and R. J. Wilson. 2018. Perspectives on corporate tax avoidance: Observations from the past decade. The Journal of the American Taxation Association Fall 201840 (2): 6381. 


\section{Appendix A - Variable Definitions}

Variable

Definition

Measures for Information Quality

External Information Quality and Disclosure

EIQ_Disp

Average Dispersion of Analysts' Forecasts - measured as the average of the standard deviation of analysts' annual earnings forecasts in the year in which Tax Risk measure is calculated. Each year, the dispersion in forecasts is measured immediately before the end of the fiscal year $(t)$ (Chen et al. 2018a; Balakrishnan et al. 2019). For ease of interpretation, I multiply the values by $(-1)$.

EIQ_Error

Absolute Analysts' Forecast Errors - measured as the average absolute analysts' forecast errors in the year $(t)$ in which Tax Risk measure is calculated. Each year, the forecast errors are the absolute value of the difference between mean analyst estimate reported immediately before the end of the fiscal year and the actual earnings for that fiscal year scaled by the price at the end of previous year (Bratten et al. 2017; Balakrishnan et al. 2019). For ease of interpretation, I multiply the values by $(-1)$.

EIQ_IDVOL Idiosyncratic return volatility measured as the five-year average of annual standard deviation of residuals from firm-specific regressions of daily returns on daily values of the Fama-French (1993) three factors plus the momentum factor (Carhartt 1997; Campbell and Taksler 2003) over years $t+1$ to $t+5$. For ease of interpretation, I multiply the values by $(-100)$.

Log_10KWord

Log_FNWord

Log_MDAWord

$\operatorname{TaxACC}$

$\operatorname{TaxAQ}$

Logarithm of the word count for references to taxes (e.g., 'Income Taxes', 'Tax') in 10-K report.

Logarithm of the word count for references to taxes (e.g., 'Income Taxes', 'Tax') in tax-related footnotes.

Logarithm of the word count for references to taxes (e.g., 'Income Taxes', 'Tax') in the MD\&A section of $10-\mathrm{K}$ report.

Total tax accrual, calculated as total tax expense scaled by total assets (TTE) less cash taxes paid scaled by total assets (CTP).

Standard deviation of the residuals from firm-specific estimates of $\operatorname{TaxACC}_{i, t}=\mathrm{b}_{0}+\mathrm{b}_{1} \mathrm{CTP}_{\mathrm{i}, \mathrm{t}-1}+\mathrm{b}_{2} \mathrm{CTP}_{\mathrm{i}, \mathrm{t}}+\mathrm{b}_{3} \mathrm{CTP}_{\mathrm{i}, \mathrm{t}+1}+\mathrm{b}_{4} \Delta \mathrm{DTL}_{-} \mathrm{LT}_{\mathrm{i}, \mathrm{t}}+$ $\mathrm{b}_{5} \Delta \mathrm{DTA} \_\mathrm{LT}_{\mathrm{i}, \mathrm{t}}+\mathrm{e}_{\mathrm{i}, \mathrm{t}}$ ) [3], multiplied by -1 , so larger values indicate better tax accrual quality (Choudhary; Koester, and Shevlin 2016). As Equation (3) is estimated over 8-year rolling windows, $\operatorname{Tax} A Q$ is calculated using residuals from $t-7$ to $t$. I use the mean of yearly estimates over the period $t+1$ to $t+5$. 
TaxAQ_FF17

$A F \_E r$

TAXEXP_Er

Internal Information Quality

IIQ_EAS (Earnings

Announcement Speed)

IIQ_EAS_FF17

IIQ_MFA (Management

Forecast Accuracy)

IIQ_No_ICW
Industry- and size-adjusted tax accrual quality $(\operatorname{Tax} A Q)$, measured as the mean $\operatorname{Tax} A Q$ of the same industry-size portfolio firms less the firm $i$ 's $\operatorname{Tax} A Q$. Size and industry are sorted independently, and industry is based on the 17 industries defined by Fama and French (1997).

Raw Analysts' Forecast Errors - measured as the average raw analysts' forecast errors in the year in Tax Risk measure is calculated. Each year, the forecast errors are the absolute value of the difference between mean analyst estimate reported immediately before the end of the fiscal year and the actual earnings for that fiscal year.

Analyst Tax Expense Forecast Errors - measured as the mean analysts' (raw) forecast errors for the I/B/E/S-based tax expense measure (TAXEXP) in the year in Tax Risk measure is calculated. TAXEXP is calculated as $\mathrm{I} / \mathrm{B} / \mathrm{E} / \mathrm{S}$-based net income (NET) minus I/B/E/S-based pretax income $(P R E)$. Each year, the forecast error for tax expense is the value of the difference between the median estimate of TAXEXP immediately before the end of the fiscal year and the actual for TAXEXP that fiscal year scaled by the price at the end of previous year. In the case that the raw mean estimate is above [below] the actual tax expense, the error is positive [negative] $\left(T A X E X P \_E r>0\right)\left[T A X E X P \_E r<0\right]$.

The number of days between the end of the fiscal year and the firm's earnings announcement for year $t$, divided by 365 . I then multiple this figure by negative one so that $E A S$ is increasing with announcement speed (Gallemore and Labro 2015).

Industry- and size-adjusted Earnings Announcement Speed, measured as the mean $I I Q \_E A S$ for the portfolio of firms in the same quintile of total assets (Size) and the same industry firms less the firm $i$ 's IIQ_EAS. Size and industry are sorted independently, and industry is based on the 17 industries defined by Fama and French (1997).

Absolute value of (management's last available estimate of EPS before year-end minus actual EPS) multiplied by (-1), divided by year-end price (Gallemore and Labro 2015).

Indicator variable equal to zero if the firm reported a Section 404 material weakness in the current fiscal year; one otherwise.

\section{Tax Planning and Tax Risk Measures}

CASH ETR

GAAP ETR
Cash effective tax rate, calculated as cash taxes paid divided by total pre-tax income less special items (TXPD/PI).

Book effective tax rate, calculated as total tax expense divided by total pre-tax income less special item (TXT/PI). 
POST

TA_CASH_1

TA_GAAP_1

TA_CASH_3

TA_CASHQ5

$T A \_G A A P \_3$

Tax Risk

Tax RiskQ5

Tax Risk_GAAP

UTBQ5

UTB2007
Indicator variable equal to one in the post-FIN 48 period (2007 to 2009) and zero in the pre-FIN 48 period (2004 to 2006).

Industry- and size-adjusted CASH ETR (following Balakrishnan et al. 2019), measured as the mean $C A S H E T R$ of the same industry-size portfolio firms less the firm $i$ 's $C A S H E T R$ in year $t$. Higher values indicate greater amounts of relative tax planning.

Industry- and size-adjusted GAAP ETR (following Balakrishnan et al. 2019), measured as the mean GAAP ETR of the same industry-size portfolio firms less the firm $i$ 's GAAP ETR in year $t$. Higher values indicate greater amounts of relative tax planning.

Industry- and size-adjusted GAAP ETR (following Balakrishnan et al. 2019), measured as the mean GAAP ETR of the same industry-size portfolio firms less the firm $i$ 's GAAP ETR, where GAAP ETR is the sum of total tax expense (TXT) over years $t$ to $t-2$ divided by the sum of pretax income $(P I)$ over years $t$ to $t-2$. Higher values indicate greater amounts of relative tax planning.

Indicator variable equal to one if a firm-year observation is in the fifth quintile of $T A \_C A S H \_3$, and zero otherwise.

Industry- and size-adjusted GAAP ETR (following Balakrishnan et al. 2019), measured as the mean GAAP ETR of the same industry-size portfolio firms less the firm $i$ 's GAAP ETR, where GAAP ETR is the sum of total tax expense (TXT) over years $t$ to $t-2$ divided by the sum of pretax income $(P I)$ over years $t$ to $t-2$. Higher values indicate greater amounts of relative tax planning.

Standard deviation of the firm's future annual cash effective tax rates $\left(T A \_C A S H \_1\right)$ over the period $t+1$ to $t+5$.

Indicator variable equal to one if a firm-year observation is in the fifth quintile of Tax Risk, and zero otherwise.

Standard deviation of the firm's future annual cash effective tax rates (TA_GAAP_l) over the period $t+1$ to $t+5$.

Indicator variable equal to one if firm $i$ has an opening UTB/total assets ratio in 2007 that is in the highest quintile, and zero otherwise (Gupta, Mills, and Towery 2014).

Indicator variable equal to one if firm $i$ has an opening unrecognized tax benefits (UTB) balance in 2007, and zero otherwise (Gupta, Mills, and Towery 2014).

\section{Proprietary Costs and Tax Complexity}

absPermDiff

The absolute value of the difference between firm $i$ 's prior year GAAP ETR and 35 percent. 
abs $\triangle E T R$

ETR_STD

I_ROA

Tax Reporting Complexity

\section{Control Variables}

Age

Analyst Following

CIC Score

CTP

$\Delta D T A \_L T$

$\Delta D T L \_L T$

Foreign Income
The standard deviation of the effective tax rate for firm $i$ over the prior five years.

The standard deviation of the quarterly effective tax rate for firm $i$ over the prior five years.

Industry- and size-adjusted return on assets (calculated as operating income before depreciation divided by average total assets) to measure abnormal segment profits (Berger and Hann 2007). I_ROA is measured at the firm level, the industry adjustment is based on the firm's primary Fama French 17 classification (Fama and French 1997), the size adjustment is based on the quintile of the firm within the industry.

The factor resulting from a principal component analysis of abs $\triangle E T R$, ETR_STD, and absPermDiff (Bratten et al. 2017).

Natural log of the difference between the first year when the firm appears in Compustat and the current year $t$.

Natural log of one plus the number of analyst estimates reported immediately before the end of the fiscal year.

CIC Score equals the probability that a firm is part of the IRS' Coordinated Industry Case program (Ayers et al. 2019). The measure uses a point system based on information presented in the IRS Internal Revenue Manual to assess the likelihood of IRS audit based on observable firm size and operational complexity characteristics.

Cash taxes paid related to income taxes (TXPD), scaled by total assets $(A T)$.

Change in the long-term portion of the deferred tax asset $\left(T X D B A_{\mathrm{i}, \mathrm{t}}\right.$ $\left.T X D B A_{\mathrm{i}, \mathrm{t}-1}\right)$, scaled by total assets $\left(A T_{\mathrm{i}, \mathrm{t}}\right)$. Following Choudhary et al. 2016, I reset missing values of $T X D B_{\mathrm{i}, \mathrm{t}}$ equal to net DTA/DTL $\left(T X N D B_{\mathrm{i}, \mathrm{t}}\right)$ less short-term DTL $\left(T X D B C L_{\mathrm{i}, \mathrm{t}}\right)$ less short-term DTA $\left(T X D B C A_{\mathrm{i}, \mathrm{t}}\right)$, with missing values of $T X D B C L_{\mathrm{i}, \mathrm{t}}\left(T X D B C A_{\mathrm{i}, \mathrm{t}}\right)$ reset to zero when $T X D B C A_{\mathrm{i}, \mathrm{t}}\left(T X D B C L_{\mathrm{i}, \mathrm{t}}\right)$ is not equal to missing. If $T X D B A_{\mathrm{i}, \mathrm{t}}$ is missing and $T X D B_{\mathrm{i}, \mathrm{t}}$ is not missing, $T X D B A_{\mathrm{i}, \mathrm{t}}$ is reset to zero.

Change in the long-term portion of the deferred tax liability $\left(T X D B_{\mathrm{i}, \mathrm{t}}\right.$ $\left.T X D B_{\mathrm{i}, \mathrm{t}-1}\right)$, scaled by total assets $\left(A T_{\mathrm{i}, \mathrm{t}}\right)$. Following Choudhary et al. 2016 , I reset missing values of $T X D B_{\mathrm{i}, \mathrm{t}}$ equal to net DTA/DTL $\left(T X N D B_{\mathrm{i}, \mathrm{t}}\right)$ less short-term DTL $\left(T X D B C L_{\mathrm{i}, \mathrm{t}}\right)$ less short-term DTA $\left(T X D B C A_{\mathrm{i}, \mathrm{t}}\right)$, with missing values of $T X D B C L_{\mathrm{i}, \mathrm{t}}\left(T X D B C A_{\mathrm{i}, \mathrm{t}}\right)$ reset to zero when $T X D B C A_{\mathrm{i}, \mathrm{t}}\left(T X D B C L_{\mathrm{i}, \mathrm{t}}\right)$ is not equal to missing. If $T X D B_{\mathrm{i}, \mathrm{t}}$ is missing and $T X D B A_{\mathrm{i}, \mathrm{t}}$ is not missing, $T X D B_{\mathrm{i}, \mathrm{t}}$ is reset to zero.

Pre-tax foreign income (PIFO), divided by average total assets Average $(A T)$. 
Geographic Complexity

Institutional Ownership

Leverage

Loss

$M T B$

Restructure

SD_Ret

Std Dev. of PTBI

Std Dev. of Sales

Size

Total Assets

TTE
Revenue-based Herfindahl-Hirschman index, calculated as the sum of the squares of each geographic segment's sales as a percentage of the total firm sales in year $t$ (Bushman et al. 2004).

Percentage of shares held by institutional owners at the end of the year. Data is obtained from the Thomson Reuters Institutional (13f) Holdings Database.

Average long-term debt (DLTT), scaled by average total assets (Average $(A T))$.

Indicator variable set to 1 if the firm reports a positive tax-loss carryforwards (TLCF), and zero otherwise.

Market to book ratio at the beginning of the year, measured as market value of equity scaled by book value of equity.

Indicator variable equal to one if the firm reports a restructuring expense $(R C P)$ during years $t+1$ to $t+5$, and zero otherwise.

Standard deviation of monthly stock returns over the subsequent year.

Standard deviation of the ratio of annual pretax book income $(P I)$ to lagged total assets $(A T)$ measured over the future five years $(t+1$ to $t+5)$.

Standard deviation of annual sales $(S A L E)$ over the future five years $(t+1$ to $t+5)$.

Natural $\log$ of average total assets $(\log (\operatorname{Average}(A T))$. The average is calculated over years $t-1$ and $t$.

Total assets $(A T)$ in year $t$.

Total tax expense (TXT), scaled by total assets $(A T)$. 
Appendix B - Incremental Contribution of Study

\begin{tabular}{|c|c|c|c|c|}
\hline Study & IIQ / EIQ & Disclosure Channel & Disclosure Costs & Findings/Incremental Contribution \\
\hline This study & IIQ + EIQ & $\begin{array}{l}\text { Voluntary }+ \\
\text { mandatory tax } \\
\text { disclosure }\end{array}$ & Proprietary & $\begin{array}{l}\text { - Tax risk breaks the link between IIQ and } \\
\text { EIQ } \\
\text { Managers appear not to disclose } \\
\text { information about tax risk but managers } \\
\text { respond to levels of tax planning and } \\
\text { business-related risk }\end{array}$ \\
\hline Balakrishnan et al. (2019) & EIQ & $\begin{array}{l}\text { Conference Calls + } \\
\text { MD\&A }\end{array}$ & Complexity & $\begin{array}{l}\text { - Tax planning negatively affects EIQ } \\
\text { - Disclosure does not mitigate the negative } \\
\text { impact }\end{array}$ \\
\hline Ehinger et al. (2020) & EIQ & Conference Calls & $\begin{array}{l}\text { Complexity }+ \\
\text { proprietary }\end{array}$ & $\begin{array}{l}\text { - Managers trade-off reporting complexity } \\
\text { and IRS scrutiny } \\
\text { - IRS scrutiny increases the costs of } \\
\text { voluntary tax-related disclosure }\end{array}$ \\
\hline Chen et al. (2018a) & $\begin{array}{l}\text { EIQ (information } \\
\text { asymmetry) }\end{array}$ & $\begin{array}{l}\text { Geographical segment } \\
\text { disclosure }\end{array}$ & Complexity & $\begin{array}{l}\text { - Income shifting is negatively associated } \\
\text { with EIQ }\end{array}$ \\
\hline Hemmer and Labro (2008) & IIQ + EIQ & - & $\begin{array}{l}\text { Complexity }+ \\
\text { proprietary }\end{array}$ & $\begin{array}{l}\text { - Theoretical framework: IIQ and EIQ are } \\
\text { inter-related }\end{array}$ \\
\hline Samuels (2020) & IIQ + EIQ & $\begin{array}{l}\text { Voluntary disclosure } \\
\text { (MD\&A) }\end{array}$ & - & $\begin{array}{l}\text { - Firms increase EIQ when contracting } \\
\text { with the government }\end{array}$ \\
\hline $\begin{array}{l}\text { Gallemore and Labro } \\
(2015)\end{array}$ & IIQ & - & - & $\begin{array}{l}\text { - IIQ is positively associated with tax } \\
\text { planning }\end{array}$ \\
\hline $\begin{array}{l}\text { Laplante et al. (2017) } \\
\text { McGuire et al. (2018) }\end{array}$ & IIQ & - & Complexity & $\begin{array}{l}\text { - IIQ is positively associated with tax- } \\
\text { motivated income shifting }\end{array}$ \\
\hline Inger et al. (2018) & EIQ & Tax disclosure quality & $\begin{array}{l}\text { Complexity }+ \\
\text { proprietary }\end{array}$ & $\begin{array}{l}\text { - Managers highlight/conceal tax savings } \\
\text { depending on relative level of firm's tax } \\
\text { planning }\end{array}$ \\
\hline
\end{tabular}




\section{Appendix C - Example of Tax Risk}

The following example is based on Drucker (2010) and Balakrishnan et al. (2019). It illustrates the substantial fluctuations in cash effective tax rates after adopting a risky tax planning strategy. Forest Laboratories is identified as a firm that undertook the "Double Irish" Sandwich transaction during 2005 (Drucker 2010). The Double Irish is a tax planning technique used by Forest Laboratories' Irish subsidiary, Forest Laboratories Holdings Ltd. The subsidiary reorganized in 2005 by creating a new Irish subsidiary, Forest Laboratories Ireland, and relocated itself to Bermuda. As depicted in the figure below, the level of effective tax rates was about $23 \%$ before 2005 before the implementation of the tax planning strategy. However, the tax planning strategy resulted in a fluctuation of cash effective tax rates. The cash effective tax rate increased to $58.2 \%$ in 2006 , dropped to $18.7 \%$ in 2007 , and increased to $36.4 \%$ in 2008 . After 2008, it stabilized at a lower level of about $20 \%$. Correspondingly, the 5-year future volatility increased from an average of approx. 0.16 before the implementation of the tax planning strategy to an average of about 0.70 after the implementation.

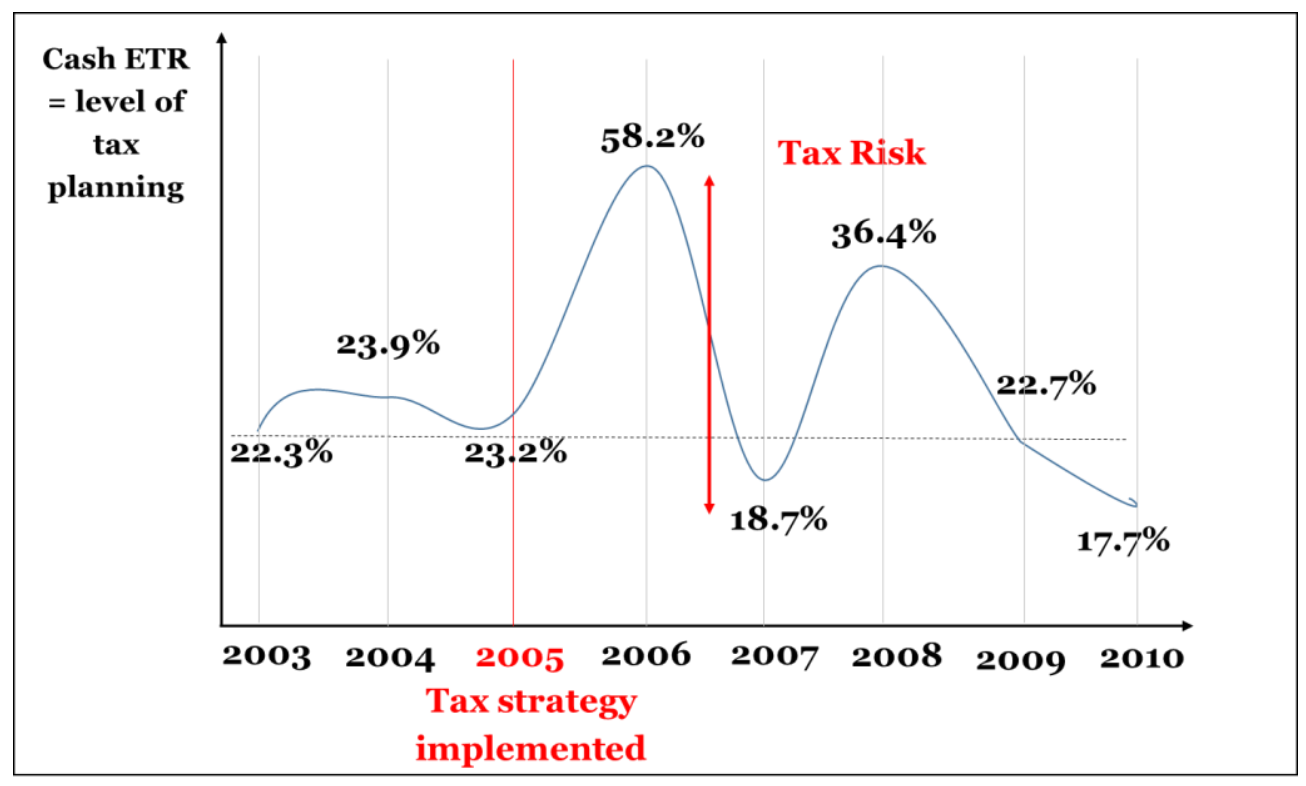


Figure 1: Relationship between Information Environment Dimensions and Tax Risk

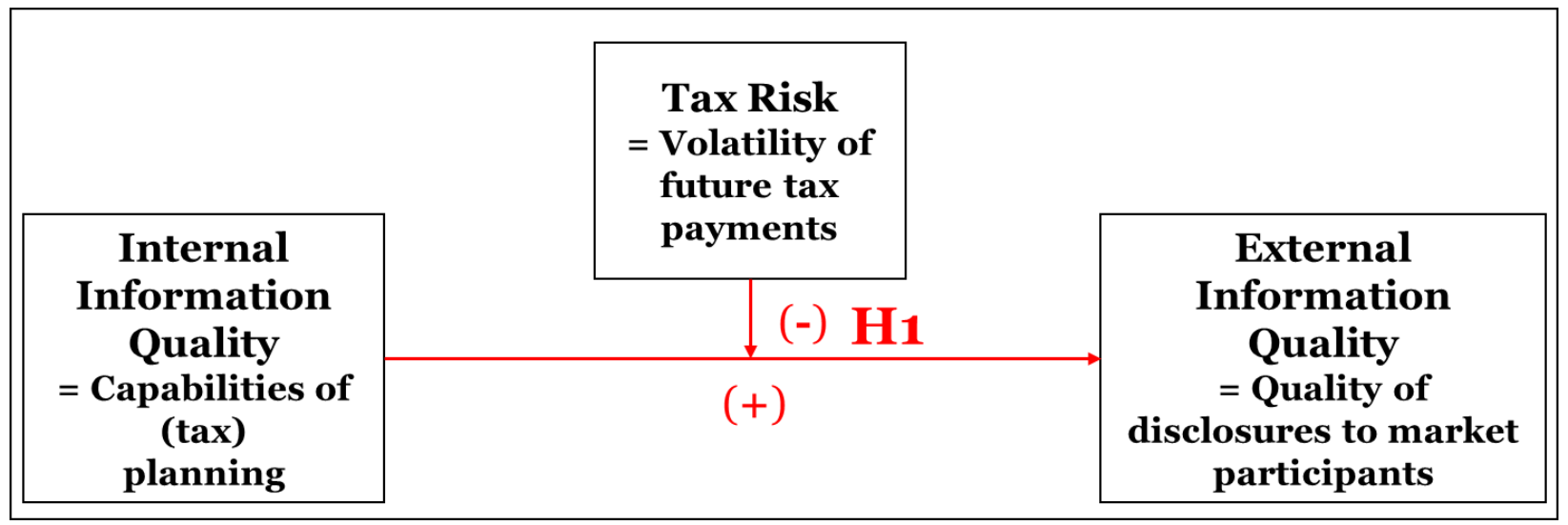

Note: This figure presents the theoretical construct and the predicted relations between the respective constructs. Hypothesis 1 predicts an attenuating effect of Tax Risk on the positive association between Internal (IIQ) and External Information Quality (EIQ).

Figure 2: Empirical Approach

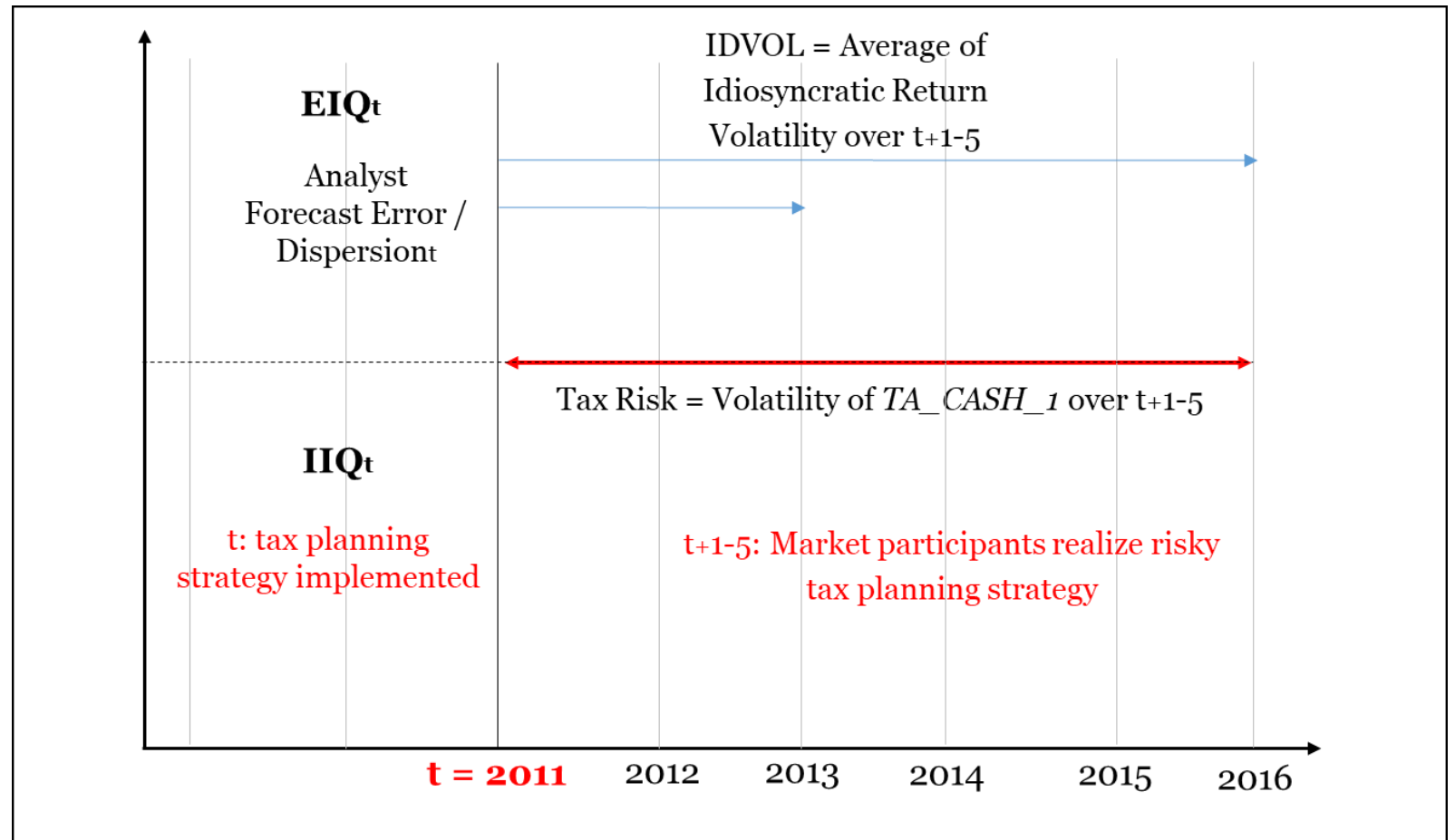

Note: This Figure illustrates the empirical approach. Managers implement a tax planning strategy in year $t=2011$ making use of internally gathered information $\left(I I Q_{t}\right)$. The implementation of the tax planning strategy results in a higher volatility of cash effective tax rates (Tax Risk) in the subsequent years $t+1$ to $t+5$. Market participants base their predictions of future economic outcomes $\left(E I Q_{t}\right.$, measured as analyst forecast errors, analyst forecast dispersion, and future idiosyncratic return volatility) on information available in 2011. 
Figure 3: SEM

Structural Equation Model Results

Panel A: Factor Loadings

\begin{tabular}{lcccccc}
\hline \hline & $(1)$ & $(2)$ & $(3)$ & $(4)$ & $(5)$ & $(6)$ \\
\hline Variable & $\mathrm{N}$ & \multicolumn{1}{c}{ Mean } & $\mathrm{SD}$ & $\mathrm{P} 25$ & Median & P75 \\
\hline IIQ_Factor & 20,680 & 0.012 & 0.266 & -0.139 & 0.055 & 0.200 \\
EIQ_Factor_1 & 20,680 & 0.002 & 0.111 & -0.011 & 0.038 & 0.063 \\
EIQ_Factor_2 & 20,680 & -0.018 & 0.434 & -0.018 & 0.119 & 0.237 \\
\hline
\end{tabular}

Panel B: SEM Results using Baseline Model (Hayes Model 1)

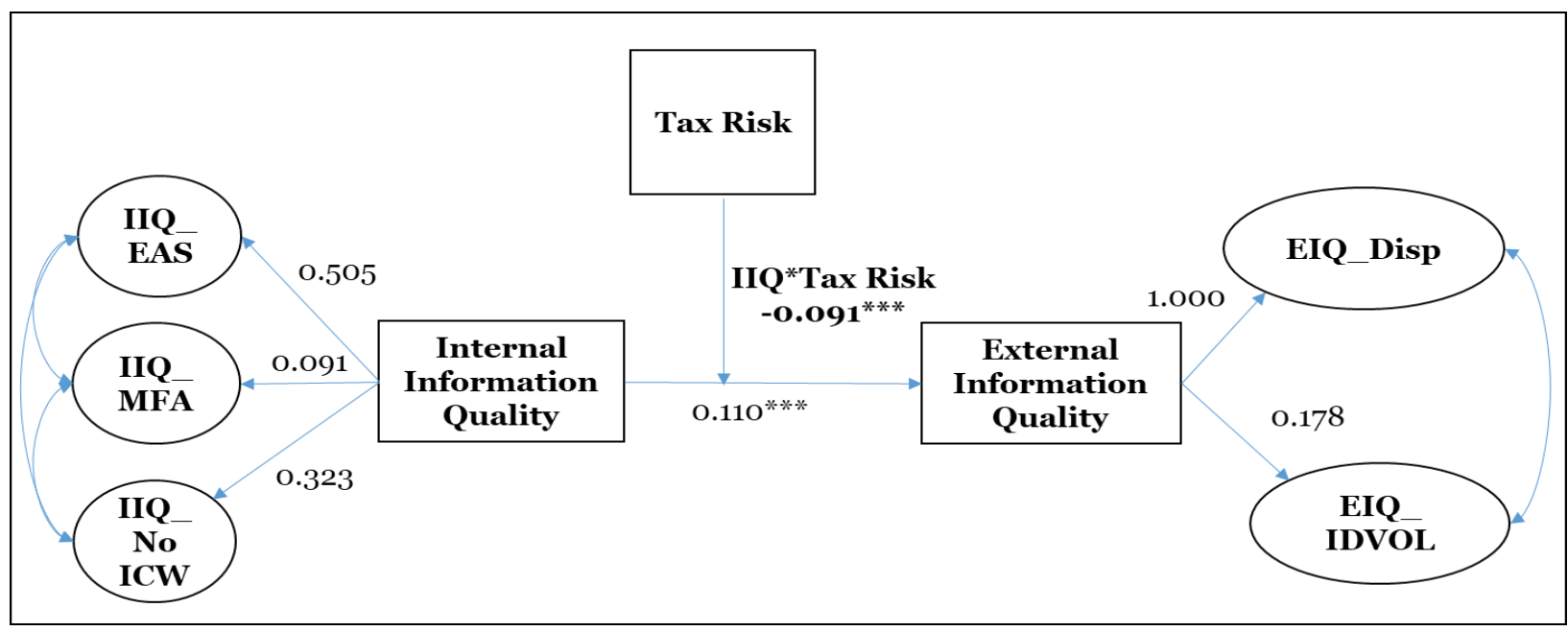

Control Variables

Yes

Observations

20,680

Goodness of fit criteria

CFI

1.000

RMSEA

0.000

SRMR

0.000

$\mathrm{Chi}^{2}$ 


\section{Panel C: SEM Results using Hayes Model 74}

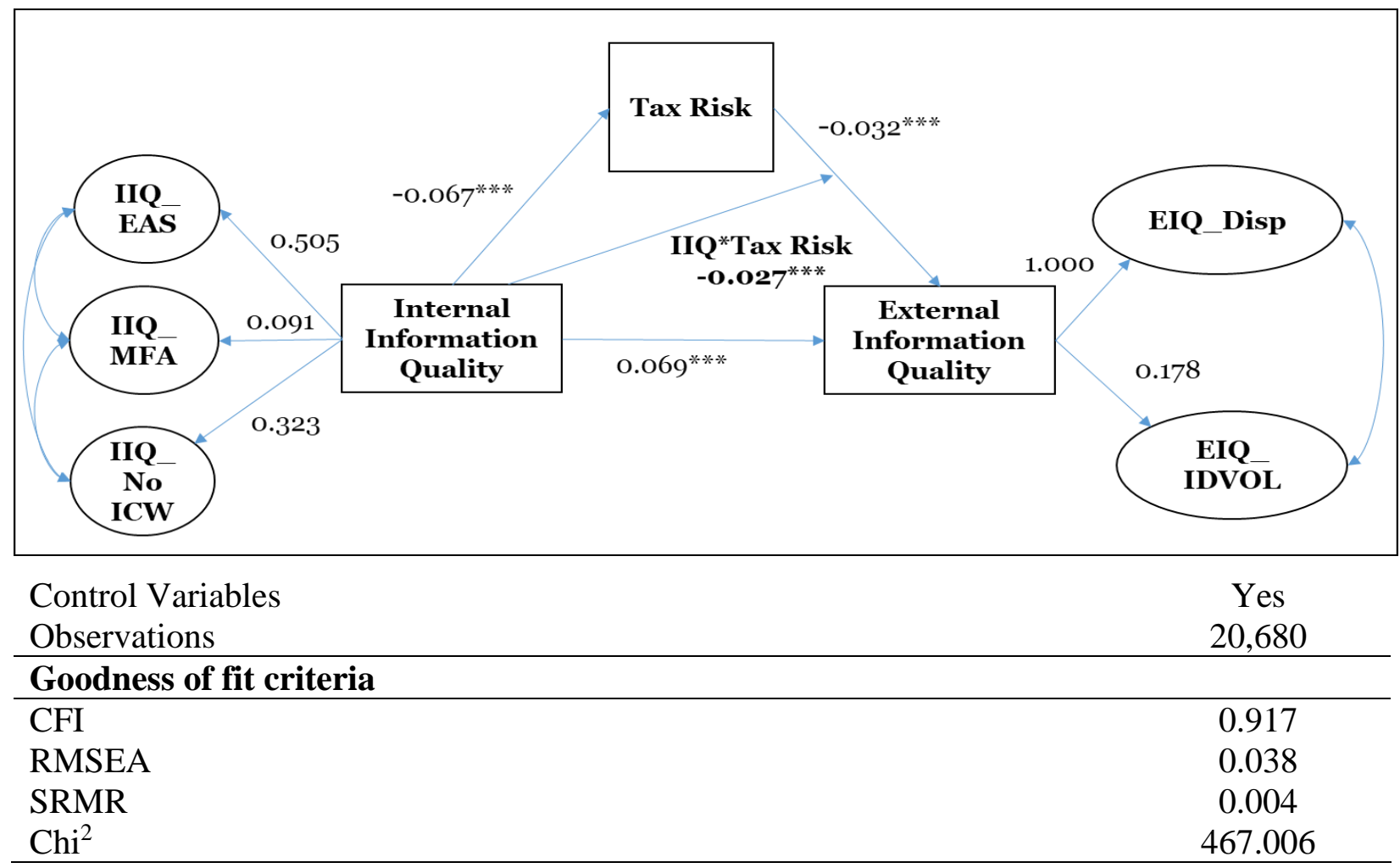

Note: This figure presents a structural equation model using equation (2) and EIQ_Factor_2. Panel A presents the factor loadings of $I I Q \_$Factor and EIQ_Factor, respectively. I estimate the factor loadings of IIQ_Factor by submitting IIQ_EAS, IIQ_MFA, and $I I Q \_N o \_I C W$ to a factor analysis. I estimate the factor loadings of EIQ_Factor_l and EIQ_Factor_2 by submitting EIQ_Error and $E I Q \_I D V O L$, and $E I Q \_D i s p$ and $E I Q \_I D V O L$ to a factor analysis, respectively. Panel B presents a structural equation model using Tax Risk as a simple moderator (Hayes Model 1). Panel C presents a structural equation model using Tax Risk as a simple moderator (Hayes Model 4) modeling Tax Risk as a mediator. Panel D presents a structural equation that is based on Hayes Model 74. EIQ_Error is the average of absolute analysts' forecast errors in the year in which the Tax Risk measure is calculated. EIQ_Disp is the average of the standard deviation of analysts' annual earnings forecasts in the year in which the Tax Risk measure is calculated. EIQ_IDVOL is the standard deviation of residuals from firm-specific regressions of daily returns on daily values of the FamaFrench (1993) three factors plus the momentum factor (Carhartt 1997; Campbell and Taksler 2003) over years $t+1$ to $t+5$, multiplied by (-100). IIQ_EAS is the earnings announcement speed in days scaled by 365 and multiplied by (-1). IIQ_MFA is the absolute value of (management's last available estimate of EPS before year-end minus actual EPS, multiplied by (-1) and divided by yearend price. IIQ_No_ICW is an indicator variable equal to zero if the firm reported a Section 404 material weakness in the current fiscal year; one otherwise. Tax Risk is the standard deviation of the firm's future annual cash effective tax rates $\left(T A \_C A S H \_1\right)$ over the period $t+1$ to $t+5$. All regressions are estimated with all control variables from equation (2) as well as industry and year fixed effects (omitted for brevity). I define variables in the Appendix A. Statistical significance at the 10\%, 5\% and 1\% level is denoted by $* * *$, and $* * *$, respectively. I use one-tailed tests when a sign is predicted and two-tailed otherwise. 
Table 1

Sample Selection

\begin{tabular}{|c|c|}
\hline Data Restrictions & $\begin{array}{c}\text { Firm-Year } \\
\text { Observations }\end{array}$ \\
\hline Total Compustat firm-year observations for fiscal years 1993 - 2016 & 187,608 \\
\hline Less: REITs (SIC 6798) & 5,211 \\
\hline Less: Observations with negative total assets and pretax income to compute ETRs & 76,343 \\
\hline Less: Observations with insufficient data to compute IIQ_EAS & 8,113 \\
\hline Less: Observations with insufficient data to compute $E I Q \_E r r o r$ and $T A \_C A S H \_l$ & 45,576 \\
\hline Less: Observations with insufficient data to compute control variables and Tax Risk & 24,896 \\
\hline Full Sample: Firms with data to compute $E I Q \_$Error & 20,680 \\
\hline Less: Observations with insufficient data to compute EIQ_Disp & 3,215 \\
\hline Subsample: Firms with data to compute EIQ_Disp & 17,465 \\
\hline Less: Observations with insufficient data to compute EIQ_IDVOL & 116 \\
\hline Subsample: Firms with data to compute $E I Q \_I D V O L$ & 20,564 \\
\hline
\end{tabular}

Note: This table presents the sample selection. The full sample (subsample) includes 20,680 $(17,465)[20,564]$ firm-year observations with available data to compute EIQ_Error (EIQ_Disp) [EIQ_IDVOL] for testing Hypothesis 1. I define variables in Appendix A. 
Table 2

Descriptive Statistics

\begin{tabular}{|c|c|c|c|c|c|c|}
\hline & $(1)$ & $(2)$ & (3) & $(4)$ & $(5)$ & $(6)$ \\
\hline Variable & $\mathrm{N}$ & Mean & SD & $\mathrm{P} 25$ & Median & P75 \\
\hline EIQ_Error & 20,680 & -0.008 & 0.011 & -0.010 & -0.005 & -0.002 \\
\hline EIQ_Disp & 17,465 & -0.313 & 0.461 & -0.346 & -0.162 & -0.074 \\
\hline$E I Q \_I D V O L$ & 20,564 & -2.226 & 0.972 & -2.749 & -2.026 & -1.509 \\
\hline$I I Q \_E A S$ & 20,680 & -0.081 & 0.024 & -0.097 & -0.077 & -0.063 \\
\hline$I I Q \_E A S \_F F 17$ & 20,680 & 0.027 & 0.024 & 0.010 & 0.028 & 0.044 \\
\hline$I I Q \_M F A$ & 4,372 & -0.006 & 0.019 & -0.004 & -0.001 & -0.000 \\
\hline$I I Q \_N o \_I C W$ & 10,030 & 0.965 & 0.185 & 1.000 & 1.000 & 1.000 \\
\hline Tax Risk & 20,680 & 0.155 & 0.120 & 0.063 & 0.121 & 0.213 \\
\hline Tax Risk_GAAP & 20,680 & 0.122 & 0.110 & 0.031 & 0.091 & 0.177 \\
\hline CASH_ETR & 20,680 & 0.286 & 0.214 & 0.140 & 0.270 & 0.372 \\
\hline GAAP ETR & 20,680 & 0.343 & 0.165 & 0.284 & 0.355 & 0.393 \\
\hline$T A \_C A S H \_1$ & 20,680 & -0.075 & 0.212 & -0.162 & -0.053 & 0.073 \\
\hline$T A \_G A A P \_1$ & 20,680 & -0.086 & 0.165 & -0.146 & -0.086 & -0.016 \\
\hline TA_CASH_3 & 20,680 & -0.033 & 0.172 & -0.118 & -0.032 & 0.080 \\
\hline$T A \_G A A P \_3$ & 20,680 & -0.057 & 0.146 & -0.122 & -0.070 & -0.003 \\
\hline Size & 20,680 & 6.848 & 1.816 & 5.524 & 6.724 & 8.006 \\
\hline Leverage & 20,680 & 0.209 & 0.193 & 0.035 & 0.177 & 0.329 \\
\hline Loss & 20,680 & 0.306 & 0.461 & 0.000 & 0.000 & 1.000 \\
\hline Foreign Income & 20,680 & 0.017 & 0.034 & 0.000 & 0.000 & 0.020 \\
\hline$M T B$ & 20,680 & 2.963 & 2.731 & 1.430 & 2.166 & 3.506 \\
\hline Age & 20,680 & 2.472 & 0.955 & 1.946 & 2.639 & 3.258 \\
\hline Analyst Following & 20,680 & 0.862 & 0.854 & 0.000 & 0.693 & 1.386 \\
\hline Geo. Complexity & 20,680 & 0.525 & 0.396 & 0.135 & 0.458 & 1.000 \\
\hline Std Dev. of Sales & 20,680 & 0.173 & 0.171 & 0.060 & 0.121 & 0.227 \\
\hline Restructure & 20,680 & 0.441 & 0.497 & 0.000 & 0.000 & 1.000 \\
\hline Inst. Owner & 20,680 & 0.608 & 0.259 & 0.420 & 0.641 & 0.809 \\
\hline$I \_R O A$ & 20,680 & 0.058 & 0.101 & -0.010 & 0.033 & 0.100 \\
\hline$S D \_R e t$ & 20,680 & 0.109 & 0.056 & 0.069 & 0.097 & 0.136 \\
\hline Std Dev. of PTBI & 20,680 & 0.058 & 0.057 & 0.019 & 0.040 & 0.077 \\
\hline TAXEXP_Er & 11,220 & -0.052 & 0.084 & -0.100 & -0.009 & 0.056 \\
\hline$A F \_E r$ & 20,680 & 0.016 & 0.091 & -0.004 & -0.001 & 0.007 \\
\hline $\operatorname{Tax} A Q$ & 5,969 & -0.005 & 0.004 & -0.007 & -0.004 & -0.003 \\
\hline$T a x A Q \_F F 17$ & 5,969 & 0.000 & 0.004 & -0.001 & 0.001 & 0.003 \\
\hline Log_10KWord & 12,090 & 4.639 & 0.651 & 4.234 & 4.673 & 5.069 \\
\hline Log_FNWord & 11,233 & 6.573 & 0.572 & 6.165 & 6.608 & 7.003 \\
\hline Log_MDAWord & 9,079 & 2.930 & 1.096 & 2.398 & 3.135 & 3.738 \\
\hline
\end{tabular}

Note: This table presents descriptive statistics for the full sample. Columns 1-6 present descriptive statistics for all firms in the sample. EIQ_Error and EIQ_Disp are winsorized at 99th percentiles. All other continuous variables are winsorized at the 1st and 99th percentiles. Variables are defined in Appendix A. 
Table 3

Correlation Table

\begin{tabular}{|c|c|c|c|c|c|c|c|c|c|c|c|c|c|c|c|c|}
\hline & Variables & (1) & (2) & (3) & (4) & (5) & (6) & (7) & (8) & (9) & (10) & (11) & (12) & (13) & (14) & (15) \\
\hline (1) & EIQ_Error & 1 & $0.938^{*}$ & $-0.067 *$ & $0.153^{*}$ & $0.240 *$ & $0.387^{*}$ & 0.007 & $-0.101 *$ & $-0.153 *$ & $0.042 *$ & $0.134 *$ & $-0.048 *$ & $-0.165 *$ & $-0.070 *$ & $-0.168 *$ \\
\hline (2) & EIQ_Disp & $0.920^{*}$ & 1 & $-0.132 *$ & $0.101^{*}$ & $0.219 *$ & $0.354 *$ & -0.012 & $-0.070 *$ & $-0.128 *$ & $0.050 *$ & $0.137 *$ & $-0.063 *$ & $-0.181 *$ & $-0.081 *$ & $-0.188 *$ \\
\hline (3) & $E I Q \_I D V O L$ & $-0.035^{*}$ & $-0.088^{*}$ & 1 & $0.127 *$ & $-0.082 *$ & $0.211^{*}$ & $0.148^{*}$ & $-0.178 *$ & $-0.280 *$ & 0.009 & $-0.088 *$ & $0.055^{*}$ & $0.228 *$ & 0.018 & $0.205^{*}$ \\
\hline (4) & $I I Q \_E A S$ & $0.114 *$ & $0.047^{*}$ & $0.137 *$ & 1 & $0.833^{*}$ & $0.141 *$ & $0.142 *$ & $-0.057 *$ & $-0.111 *$ & $0.064 *$ & 0.009 & $-0.030 *$ & $0.022 *$ & $-0.055^{*}$ & -0.013 \\
\hline (5) & $I I Q \_E A S \_F F 17$ & $0.179 *$ & $0.137^{*}$ & $-0.084 *$ & $0.845^{*}$ & 1 & $0.122 *$ & $0.120 *$ & $-0.055^{*}$ & $-0.091^{*}$ & $0.050 *$ & $0.074 *$ & $-0.082 *$ & $-0.131 *$ & $-0.106^{*}$ & $-0.156^{*}$ \\
\hline (6) & $I I Q \_M F A$ & $0.301 *$ & $0.309^{*}$ & $0.149 *$ & $0.040 *$ & 0.034 & 1 & $0.066^{*}$ & $-0.110 *$ & $-0.142 *$ & -0.011 & 0.003 & 0.035 & 0.030 & 0.020 & 0.009 \\
\hline (7) & $I I Q \_N o \_I C W$ & 0.007 & -0.015 & $0.153^{*}$ & $0.186^{*}$ & $0.155^{*}$ & 0.029 & 1 & $-0.059 *$ & $-0.080 *$ & -0.011 & -0.013 & 0.017 & 0.025 & -0.009 & -0.001 \\
\hline (8) & Tax Risk_CASH & $-0.066^{*}$ & $-0.044^{*}$ & $-0.163^{*}$ & $-0.062 *$ & $-0.061 *$ & $-0.055^{*}$ & $-0.064 *$ & 1 & $0.571 *$ & $0.156^{*}$ & $0.124 *$ & $-0.153 *$ & $-0.132 *$ & $-0.137 *$ & $-0.117 *$ \\
\hline (9) & Tax Risk_GAAP & $-0.094 *$ & $-0.075^{*}$ & $-0.238 *$ & $-0.103 *$ & $-0.087 *$ & $-0.045^{*}$ & $-0.079 *$ & $0.574^{*}$ & 1 & $-0.024 *$ & $0.029 *$ & 0.015 & $-0.059 *$ & $0.046^{*}$ & -0.009 \\
\hline (10) & CASH_ETR & -0.015 & -0.012 & -0.011 & $0.021 *$ & 0.001 & $-0.086 *$ & $-0.035 *$ & $0.137 *$ & $0.031 *$ & 1 & $0.412 *$ & $-0.974 *$ & $-0.390 *$ & $-0.629 *$ & $-0.290 *$ \\
\hline (11) & GAAP ETR & $0.082 *$ & $0.077 *$ & $-0.026^{*}$ & $0.022 *$ & $0.039 *$ & $-0.047^{*}$ & $-0.027 *$ & $0.110^{*}$ & $0.065^{*}$ & $0.473^{*}$ & 1 & $-0.401 *$ & $-0.898 *$ & $-0.298^{*}$ & $-0.547 *$ \\
\hline (12) & TA_CASH_l & 0.013 & 0.009 & $0.067 *$ & 0.009 & $-0.028^{*}$ & $0.090 *$ & $0.041 *$ & $-0.134 *$ & $-0.035^{*}$ & $-0.985^{*}$ & $-0.462 *$ & 1 & $0.451 *$ & $0.656^{*}$ & $0.353^{*}$ \\
\hline (13) & $T A \_G A A P \_1$ & $-0.098 *$ & $-0.100 *$ & $0.141 *$ & 0.013 & $-0.082 *$ & $0.057 *$ & $0.040 *$ & $-0.113 *$ & $-0.078 *$ & $-0.459 *$ & $-0.967^{*}$ & $0.484 *$ & 1 & $0.352 *$ & $0.664 *$ \\
\hline (14) & TA_CASH_3 & $-0.029 *$ & $-0.033 *$ & $0.025^{*}$ & $-0.032 *$ & $-0.070 *$ & 0.016 & 0.006 & $-0.117 *$ & 0.001 & $-0.475^{*}$ & $-0.228 *$ & $0.492 *$ & $0.258 *$ & 1 & $0.504 *$ \\
\hline (15) & $T A \_G A A P \_3$ & $-0.097^{*}$ & $-0.094^{*}$ & $0.112^{*}$ & $-0.028^{*}$ & $-0.120^{*}$ & -0.005 & -0.001 & $-0.098^{*}$ & -0.017 & $-0.201 *$ & $-0.388^{*}$ & $0.230^{*}$ & $0.438 *$ & $0.482 *$ & 1 \\
\hline (16) & Size & $-0.217 *$ & $-0.305^{*}$ & $0.618^{*}$ & $0.221 *$ & $-0.123 *$ & $0.068^{*}$ & $0.117 *$ & $-0.049 *$ & $-0.052 *$ & $-0.018 *$ & $-0.020 *$ & $0.093 *$ & $0.167 *$ & $0.075^{*}$ & $0.163^{*}$ \\
\hline (17) & Leverage & $-0.065^{*}$ & $-0.049^{*}$ & $0.069^{*}$ & $-0.072 *$ & $-0.100 *$ & -0.016 & 0.025 & -0.005 & $0.047 *$ & $-0.029 *$ & $0.072 *$ & $0.052 *$ & -0.008 & $0.064 *$ & $0.025^{*}$ \\
\hline (18) & Loss & $-0.062^{*}$ & $-0.071^{*}$ & $0.055^{*}$ & $-0.090 *$ & $-0.120 *$ & 0.017 & -0.010 & -0.004 & $0.094 *$ & $-0.095^{*}$ & $-0.048^{*}$ & $0.106^{*}$ & $0.062 *$ & $0.135^{*}$ & $0.103^{*}$ \\
\hline (19) & Foreign Income & -0.015 & $-0.062 *$ & $0.137 *$ & $0.054 *$ & $-0.037 *$ & $0.049 *$ & 0.013 & 0.010 & $0.019 *$ & $-0.047^{*}$ & $-0.101 *$ & $0.074 *$ & $0.131 *$ & $0.085^{*}$ & $0.122 *$ \\
\hline (20) & $M T B$ & $0.160 *$ & $0.137 *$ & 0.007 & $0.152 *$ & $0.188 *$ & $0.096^{*}$ & 0.016 & $-0.078 *$ & $-0.055^{*}$ & $-0.044 *$ & 0.013 & $0.047 *$ & $-0.022 *$ & $0.048^{*}$ & $-0.025 *$ \\
\hline (21) & Age & $-0.059 *$ & $-0.076^{*}$ & $0.450 *$ & $0.136^{*}$ & $-0.020^{*}$ & $0.048 *$ & $0.039 *$ & $-0.039 *$ & $-0.088 *$ & $0.021 *$ & $-0.020 *$ & $0.020^{*}$ & $0.098 *$ & -0.004 & $0.090^{*}$ \\
\hline$(22)$ & Analyst Follow. & $-0.053^{*}$ & $-0.187^{*}$ & $0.289^{*}$ & $0.230^{*}$ & $0.047 *$ & $0.076^{*}$ & $0.065^{*}$ & $-0.069 *$ & $-0.034 *$ & $-0.051 *$ & $-0.041 *$ & $0.087 *$ & $0.101 *$ & $0.105^{*}$ & $0.107^{*}$ \\
\hline (23) & Geo. Complexity & $-0.020 *$ & 0.014 & $-0.036^{*}$ & -0.05 & 0.0 & -0.0 & 0.0 & -0.0 & -0.1 & -0.010 & 0.0 & -0.0 & $-0.026^{*}$ & -0.0 & $-0.081 *$ \\
\hline (24) & Std Dev. Sales & $-0.137 *$ & $-0.217^{*}$ & $0.224 *$ & $0.125^{*}$ & -0.005 & 0.020 & $0.049 *$ & $-0.036^{*}$ & $-0.039 *$ & -0.004 & -0.004 & $0.039 *$ & $0.066^{*}$ & $0.037 *$ & $-0.075^{*}$ \\
\hline (25) & Restrcuture & -0.015 & $-0.020^{*}$ & $0.063^{*}$ & $0.030 *$ & $-0.048^{*}$ & 0.029 & -0.021 & $0.094 *$ & $0.202 *$ & -0.001 & $0.047 *$ & $0.035^{*}$ & 0.001 & $0.087^{*}$ & $0.073^{*}$ \\
\hline (26) & Inst. Owner & $-0.078 *$ & $-0.140 *$ & $0.304 *$ & $0.102 *$ & $-0.061 *$ & $0.085^{*}$ & $0.029 *$ & -0.008 & $0.049 *$ & $-0.035^{*}$ & $0.067 *$ & $0.073 *$ & 0.007 & $0.092 *$ & $0.035^{*}$ \\
\hline (27) & $I \_R O A$ & $0.115^{*}$ & $0.099^{*}$ & $-0.187^{*}$ & $0.048^{*}$ & $0.254^{*}$ & 0.026 & $0.031 *$ & $-0.053^{*}$ & $-0.095^{*}$ & 0.002 & $0.037^{*}$ & $-0.056^{*}$ & $-0.147 *$ & $-0.064 *$ & $-0.174 *$ \\
\hline (28) & SD_Ret & $-0.089 *$ & $-0.064 *$ & $-0.607 *$ & $-0.067 *$ & $0.034 *$ & $-0.127 *$ & $-0.049 *$ & $0.092 *$ & $0.159 *$ & 0.012 & $0.020 *$ & $-0.048 *$ & $-0.090 *$ & -0.005 & $-0.061 *$ \\
\hline (29) & Std Dev. PTBI & $-0.026^{*}$ & $-0.028^{*}$ & $-0.489 *$ & $-0.046^{*}$ & $0.092 *$ & $-0.057 *$ & $-0.060 *$ & $0.112^{*}$ & $0.214^{*}$ & $-0.044 *$ & -0.001 & 0.003 & $-0.069 *$ & $0.033^{*}$ & $-0.037 *$ \\
\hline
\end{tabular}


Table 3 (continued)

\section{Correlation Table}

\begin{tabular}{|c|c|c|c|c|c|c|c|c|c|c|c|c|c|c|c|}
\hline & Variables & (16) & $(17)$ & $(18)$ & (19) & $(20)$ & $(21)$ & $(22)$ & $(23)$ & $(24)$ & $(25)$ & $(26)$ & $(27)$ & $(28)$ & (29) \\
\hline (1) & EIQ_Error & $-0.224 *$ & $-0.106^{*}$ & $-0.090 *$ & -0.010 & $0.313^{*}$ & $-0.117 *$ & $-0.068^{*}$ & 0.008 & $-0.051 *$ & $-0.088^{*}$ & $-0.122 *$ & $0.209^{*}$ & $-0.078^{*}$ & -0.012 \\
\hline (2) & EIQ_Disp & $-0.321 *$ & $-0.097 *$ & $-0.115^{*}$ & $-0.061 *$ & $0.261 *$ & $-0.141 *$ & $-0.211 *$ & $0.058 *$ & $-0.160 *$ & $-0.115^{*}$ & $-0.207 *$ & $0.196^{*}$ & $-0.058 *$ & -0.011 \\
\hline (3) & $E I Q \_I D V O L$ & $0.656^{*}$ & $0.138 *$ & $0.048^{*}$ & $0.178 *$ & $0.030 *$ & $0.481 *$ & $0.294 *$ & $-0.068 *$ & $0.403 *$ & $0.066^{*}$ & $0.256^{*}$ & $-0.162 *$ & $-0.638 *$ & $-0.534 *$ \\
\hline (4) & $I I Q \_E A S$ & $0.206^{*}$ & $-0.061 *$ & $-0.099 *$ & $0.068 *$ & $0.184 *$ & $0.125^{*}$ & $0.208 *$ & $-0.033 *$ & $0.177 *$ & $0.020 *$ & $0.044^{*}$ & $0.083^{*}$ & $-0.066^{*}$ & $-0.046^{*}$ \\
\hline (5) & $I I Q \_E A S \_F F 17$ & $-0.133 *$ & $-0.106^{*}$ & $-0.127 *$ & $-0.047^{*}$ & $0.215 *$ & $-0.036^{*}$ & $0.028 *$ & $0.048 *$ & $-0.044 *$ & $-0.052 *$ & $-0.095^{*}$ & $0.241 *$ & $0.034 *$ & $0.099 *$ \\
\hline (6) & $I I Q \_M F \bar{A}$ & $0.138^{*}$ & -0.035 & -0.007 & $0.092 *$ & $0.280 *$ & $0.066^{*}$ & $0.138 *$ & $-0.050 *$ & $0.182 *$ & 0.012 & $0.059 *$ & $0.171 *$ & $-0.202 *$ & $-0.072 *$ \\
\hline (7) & $I I Q \_N o \_I C W$ & $0.120 *$ & $0.037^{*}$ & -0.010 & -0.004 & 0.005 & $0.042 *$ & $0.067 *$ & $0.032 *$ & $0.087 *$ & -0.021 & 0.023 & $0.044 *$ & $-0.049 *$ & $-0.076^{*}$ \\
\hline (8) & TaxRisk_CASH & $-0.058 *$ & 0.004 & -0.007 & $0.034^{*}$ & $-0.098 *$ & $-0.026^{*}$ & $-0.076^{*}$ & $-0.060 *$ & $-0.055^{*}$ & $0.099 *$ & -0.008 & $-0.057 *$ & $0.099 *$ & $0.177 *$ \\
\hline (9) & Tax Risk_GAAP & $-0.065 *$ & $0.045^{*}$ & $0.108^{*}$ & $0.065^{*}$ & $-0.099 *$ & $-0.097 *$ & $-0.037 *$ & $-0.143 *$ & $-0.070 *$ & $0.231 *$ & $0.051 *$ & $-0.117 *$ & $0.194 *$ & $0.323 *$ \\
\hline (10) & CASH_ETR & $-0.039 *$ & $-0.038 *$ & $-0.138 *$ & $-0.033^{*}$ & -0.008 & $0.033 *$ & $-0.053^{*}$ & $0.031 *$ & $-0.025^{*}$ & $-0.028 *$ & $-0.049^{*}$ & $0.073^{*}$ & -0.016 & $-0.044 *$ \\
\hline (11) & GAAP ETR & $-0.095 *$ & $0.106^{*}$ & $-0.091 *$ & $-0.147 *$ & $0.035^{*}$ & $-0.068 *$ & $-0.074 *$ & $0.125^{*}$ & $0.024 *$ & 0.003 & $0.033^{*}$ & $0.118^{*}$ & $0.051^{*}$ & $0.048 *$ \\
\hline (12) & TA_CASH_l & $0.132 *$ & $0.0^{7}$ & $0.151 *$ & $0.073 *$ & 0.0 & 0.0 & 0.0 & $-0.049 *$ & 0.1 & 0.0 & 0.0 & -0.1 & $-0.028 *$ & 0.000 \\
\hline (13) & $T A \_G A A P_{-} l$ & $0.294 *$ & 0.015 & $0.109 *$ & $0.178 *$ & $-0.043 *$ & $0.172 *$ & $0.149 *$ & $-0.119 *$ & $0.164 *$ & $0.058 *$ & $0.056^{*}$ & $-0.231 *$ & $-0.145 *$ & $-0.132 *$ \\
\hline (14) & TA_CASH_3 & $0.110^{*}$ & $0.065^{*}$ & $0.184 *$ & $0.108 *$ & $0.037^{*}$ & -0.009 & $0.119 *$ & $-0.100 *$ & $0.101 *$ & $0.119^{*}$ & $0.124 *$ & $-0.105^{*}$ & -0.004 & $0.044 *$ \\
\hline (15) & $T A \_G A A P \_3$ & $0.283 *$ & $0.045^{*}$ & $0.143^{*}$ & $0.198 *$ & $-0.038 *$ & $0.175^{*}$ & $0.158 *$ & $-0.173 *$ & $0.183^{*}$ & $0.125 *$ & $0.089 *$ & $-0.234 *$ & $-0.121 *$ & $-0.093^{*}$ \\
\hline (16) & Size & 1 & $0.304 *$ & $0.099 *$ & $0.202 *$ & $-0.039 *$ & $0.403^{*}$ & $0.434 *$ & $-0.097 *$ & $0.706^{*}$ & $0.142 *$ & $0.310 *$ & $-0.372 *$ & $-0.379 *$ & $-0.412 *$ \\
\hline (17) & Leverage & $0.227 *$ & 1 & $0.032 *$ & $-0.020^{*}$ & $-0.150 *$ & $0.082 *$ & $-0.059 *$ & $0.059 *$ & $0.225^{*}$ & $0.043 *$ & -0.004 & $-0.228 *$ & $-0.101 *$ & $-0.197 *$ \\
\hline (18) & Loss & $0.084 *$ & $0.030 *$ & 1 & $0.229 *$ & $0.026 *$ & 0.010 & $0.148 *$ & $-0.268 *$ & $0.115^{*}$ & $0.246 *$ & $0.200 *$ & $-0.077 *$ & $0.031 *$ & $0.037 *$ \\
\hline (19) & Foreign Income & $0.154^{*}$ & $-0.078^{*}$ & $0.186^{*}$ & 1 & $0.194 *$ & $0.175^{*}$ & $0.215^{*}$ & $-0.592 *$ & $0.223 *$ & $0.331 *$ & $0.231 *$ & $0.036^{*}$ & $-0.049 *$ & $0.043 *$ \\
\hline (20) & $M T B$ & $-0.030 *$ & $-0.067 *$ & 0.017 & $0.215^{*}$ & 1 & $-0.038 *$ & $0.207^{*}$ & $-0.188 *$ & $0.172 *$ & $0.109 *$ & $0.126^{*}$ & $0.457 *$ & 0.010 & $0.210^{*}$ \\
\hline (21) & Age & $0.376^{*}$ & -0.005 & 0.016 & $0.115^{*}$ & $-0.061 *$ & 1 & $0.113^{*}$ & $-0.106^{*}$ & $0.258 *$ & $0.142 *$ & $0.149 *$ & $-0.144 *$ & $-0.332 *$ & $-0.234^{*}$ \\
\hline (22) & Analyst Follow. & $0.445^{*}$ & $-0.077 *$ & $0.152 *$ & $0.234 *$ & $0.174 *$ & $0.127 *$ & 1 & $-0.167 *$ & $0.380 *$ & $0.188 *$ & $0.422 *$ & -0.003 & $-0.079 *$ & $-0.044^{*}$ \\
\hline (23) & Geo. Complexity & $-0.056^{*}$ & $0.070 *$ & $-0.241 *$ & $-0.460 *$ & $-0.133 *$ & $-0.073 *$ & $-0.144 *$ & 1 & $-0.171^{*}$ & $-0.372 *$ & $-0.176^{*}$ & $-0.018^{*}$ & $-0.043 *$ & $-0.131 *$ \\
\hline (24) & Std Dev. Sales & $0.522 *$ & $0.090^{*}$ & $0.047 *$ & $0.133 *$ & $0.051^{*}$ & $0.154 *$ & $0.270^{*}$ & $-0.081 *$ & 1 & $0.164 *$ & $0.318^{*}$ & $-0.128 *$ & $-0.197 *$ & $0.597 *$ \\
\hline (25) & Restrcuture & $0.131^{*}$ & $0.028^{*}$ & $0.246^{*}$ & $0.247 *$ & $0.078^{*}$ & $0.133^{*}$ & $0.190^{*}$ & $-0.344 *$ & $0.066^{*}$ & 1 & $0.270^{*}$ & $-0.051 *$ & $0.049 *$ & $0.125 *$ \\
\hline (26) & Inst. Owner & $0.302 *$ & -0.012 & $0.189 *$ & $0.169 *$ & $0.086^{*}$ & $0.181^{*}$ & $0.407^{*}$ & $-0.144 *$ & $0.083^{*}$ & $0.269^{*}$ & 1 & $-0.055^{*}$ & $-0.062 *$ & -0.005 \\
\hline (27) & $I \_R O A$ & $-0.386^{*}$ & $-0.181 *$ & $-0.093^{*}$ & $0.098 *$ & $0.402 *$ & $-0.162 *$ & $-0.025^{*}$ & 0.005 & $-0.100^{*}$ & $-0.071 *$ & $-0.082^{*}$ & 1 & $0.156^{*}$ & $0.325^{*}$ \\
\hline (28) & $\overline{S D} \_R e t$ & $-0.348 *$ & $-0.050 *$ & $0.023 *$ & $-0.026^{*}$ & $0.054^{*}$ & $-0.309 *$ & $-0.077 *$ & $-0.044 *$ & $-0.135^{*}$ & $0.054 *$ & $-0.096^{*}$ & $0.174 *$ & 1 & $0.370 *$ \\
\hline (29) & Std Dev. PTBI & $-0.345^{*}$ & $-0.157 *$ & $0.021 *$ & $0.027 *$ & $0.191 *$ & $-0.221 *$ & $-0.030 *$ & $-0.074 *$ & $0.504 *$ & $0.079 *$ & $-0.037 *$ & $0.315^{*}$ & $0.335^{*}$ & 1 \\
\hline
\end{tabular}

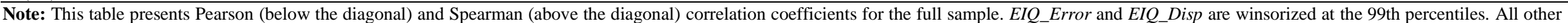

continuous variables are winsorized at the 1st and 99th percentiles. Variables are defined in Appendix A. * indicates statistical significance at the $1 \%$ level. Variables are defined in Appendix A. 
Table 4

Association of IIQ and EIQ (Baseline Tests)

\begin{tabular}{|c|c|c|c|c|c|c|c|}
\hline Variables & $\begin{array}{l}\text { Pred. } \\
\text { Sign }\end{array}$ & $\begin{array}{c}(1) \\
\text { EIQ_Error }\end{array}$ & $\begin{array}{c}(2) \\
\text { EIQ_Error }\end{array}$ & $\begin{array}{c}(3) \\
\text { EIQ_Disp }\end{array}$ & $\begin{array}{c}\text { (4) } \\
\text { EIQ_Disp }\end{array}$ & $\begin{array}{c}(5) \\
E I Q \_I D V O L\end{array}$ & $\begin{array}{c}\text { (6) } \\
E I Q \_I D V O L\end{array}$ \\
\hline IIQ_EAS & + & $\begin{array}{c}0.347 * * * \\
(\mathbf{0 . 0 8 3})\end{array}$ & & $\begin{array}{c}0.924 * * \\
(0.372)\end{array}$ & & $\begin{array}{c}0.019 * * * \\
(0.006)\end{array}$ & \\
\hline$I I Q \_E A S \_F F 17$ & + & & $\begin{array}{c}0.323 * * * \\
(0.080)\end{array}$ & & $\begin{array}{l}0.868 * * \\
(0.358)\end{array}$ & & $\begin{array}{l}\text { 0.009* } \\
(0.005)\end{array}$ \\
\hline Size & & $\begin{array}{c}-0.017 * * * \\
(0.003)\end{array}$ & $\begin{array}{c}-0.016 * * * \\
(0.003)\end{array}$ & $\begin{array}{c}-0.091 * * * \\
(0.013)\end{array}$ & $\begin{array}{c}-0.087 * * * \\
(0.013)\end{array}$ & $\begin{array}{c}0.002 * * * \\
(0.000)\end{array}$ & $\begin{array}{c}0.002 * * * \\
(0.000)\end{array}$ \\
\hline Leverage & & $\begin{array}{l}-0.016^{*} \\
(0.008)\end{array}$ & $\begin{array}{l}-0.016^{*} \\
(0.008)\end{array}$ & $\begin{array}{l}-0.019 \\
(0.037)\end{array}$ & $\begin{array}{l}-0.021 \\
(0.037)\end{array}$ & $\begin{array}{c}-0.003 * * * \\
(0.001)\end{array}$ & $\begin{array}{c}-0.003 * * * \\
(0.001)\end{array}$ \\
\hline Loss & & $\begin{array}{c}0.001 \\
(0.003)\end{array}$ & $\begin{array}{c}0.001 \\
(0.003)\end{array}$ & $\begin{array}{c}0.004 \\
(0.011)\end{array}$ & $\begin{array}{c}0.003 \\
(0.011)\end{array}$ & $\begin{array}{l}-0.000 \\
(0.000)\end{array}$ & $\begin{array}{l}-0.000 \\
(0.000)\end{array}$ \\
\hline Foreign Income & & $\begin{array}{l}-0.027 \\
(0.044)\end{array}$ & $\begin{array}{l}-0.025 \\
(0.044)\end{array}$ & $\begin{array}{l}-0.273 \\
(0.213)\end{array}$ & $\begin{array}{l}-0.269 \\
(0.213)\end{array}$ & $\begin{array}{c}0.000 \\
(0.002)\end{array}$ & $\begin{array}{c}0.000 \\
(0.002)\end{array}$ \\
\hline$M T B$ & & $\begin{array}{c}0.005 * * * \\
(0.001)\end{array}$ & $\begin{array}{c}0.005 * * * \\
(0.001)\end{array}$ & $\begin{array}{c}0.020 * * * \\
(0.002)\end{array}$ & $\begin{array}{c}0.020 * * * \\
(0.002)\end{array}$ & $\begin{array}{c}0.000 * * * \\
(0.000)\end{array}$ & $\begin{array}{c}0.000 * * * \\
(0.000)\end{array}$ \\
\hline Age & & $\begin{array}{l}-0.001 \\
(0.002)\end{array}$ & $\begin{array}{l}-0.001 \\
(0.001)\end{array}$ & $\begin{array}{c}0.005 \\
(0.006)\end{array}$ & $\begin{array}{c}0.005 \\
(0.006)\end{array}$ & $\begin{array}{c}0.001 * * * \\
(0.000)\end{array}$ & $\begin{array}{c}0.001 * * * \\
(0.000)\end{array}$ \\
\hline Analyst Follow. & & $\begin{array}{c}0.011 * * * \\
(0.003)\end{array}$ & $\begin{array}{c}0.012 * * * \\
(0.003)\end{array}$ & $\begin{array}{l}-0.009 \\
(0.008)\end{array}$ & $\begin{array}{l}-0.008 \\
(0.008)\end{array}$ & $\begin{array}{l}-0.000 \\
(0.000)\end{array}$ & $\begin{array}{l}-0.000 \\
(0.000)\end{array}$ \\
\hline Geo. Complexity & & $\begin{array}{c}0.000 \\
(0.004)\end{array}$ & $\begin{array}{c}0.000 \\
(0.004)\end{array}$ & $\begin{array}{c}0.005 \\
(0.019)\end{array}$ & $\begin{array}{c}0.005 \\
(0.019)\end{array}$ & $\begin{array}{c}-0.001 * * * \\
(0.000)\end{array}$ & $\begin{array}{c}-0.001 * * * \\
(0.000)\end{array}$ \\
\hline Std Dev. Sales & & $\begin{array}{c}-0.028 * * \\
(0.011)\end{array}$ & $\begin{array}{c}-0.028 * * \\
(0.011)\end{array}$ & $\begin{array}{c}-0.131 * * * \\
(0.045)\end{array}$ & $\begin{array}{c}-0.132 * * * \\
(0.045)\end{array}$ & $\begin{array}{l}-0.001 \\
(0.000)\end{array}$ & $\begin{array}{l}-0.001 \\
(0.000)\end{array}$ \\
\hline Restructure & & $\begin{array}{c}0.004 \\
(0.004)\end{array}$ & $\begin{array}{c}0.004 \\
(0.004)\end{array}$ & $\begin{array}{c}0.023 \\
(0.014)\end{array}$ & $\begin{array}{c}0.023 \\
(0.014)\end{array}$ & $\begin{array}{c}-0.000 * * \\
(0.000)\end{array}$ & $\begin{array}{l}-0.000^{*} \\
(0.000)\end{array}$ \\
\hline Inst. Owner. & & $\begin{array}{l}-0.005 \\
(0.009)\end{array}$ & $\begin{array}{l}-0.004 \\
(0.009)\end{array}$ & $\begin{array}{l}-0.076^{*} \\
(0.037)\end{array}$ & $\begin{array}{l}-0.072 * \\
(0.037)\end{array}$ & $\begin{array}{c}0.004 * * * \\
(0.001)\end{array}$ & $\begin{array}{c}0.004 * * * \\
(0.000)\end{array}$ \\
\hline$I \_R O A$ & & $\begin{array}{l}-0.017 \\
(0.018)\end{array}$ & $\begin{array}{l}-0.023 \\
(0.018)\end{array}$ & $\begin{array}{c}-0.275^{* * *} \\
(0.077)\end{array}$ & $\begin{array}{c}-0.288 * * * \\
(0.077)\end{array}$ & $\begin{array}{c}0.007 * * * \\
(0.001)\end{array}$ & $\begin{array}{c}0.007 * * * \\
(0.001)\end{array}$ \\
\hline$S D \_R e t$ & & $\begin{array}{c}-0.334 * * * \\
(0.042)\end{array}$ & $\begin{array}{c}-0.335 * * * \\
(0.042)\end{array}$ & $\begin{array}{c}-1.447 * * * \\
(0.207)\end{array}$ & $\begin{array}{c}-1.452 * * * \\
(0.207)\end{array}$ & $\begin{array}{c}-0.065^{* * *} * \\
(0.003)\end{array}$ & $\begin{array}{c}-0.065^{* * *} * \\
(0.003)\end{array}$ \\
\hline Std Dev. PTBI & & $\begin{array}{c}-0.197 * * * \\
(0.026) \\
\end{array}$ & $\begin{array}{c}-0.198 * * * \\
(0.026)\end{array}$ & $\begin{array}{c}-0.768 * * * \\
(0.110)\end{array}$ & $\begin{array}{c}-0.774 * * * \\
(0.112) \\
\end{array}$ & $\begin{array}{c}-0.038 * * * \\
(0.002)\end{array}$ & $\begin{array}{c}-0.038 * * * \\
(0.002)\end{array}$ \\
\hline Observations & & 20,680 & 20,680 & 17,465 & 17,465 & 20,564 & 20,564 \\
\hline Adj. R-squared & & 0.204 & 0.204 & 0.260 & 0.259 & 0.713 & 0.712 \\
\hline Ind. \& Year FE & & Yes & Yes & Yes & Yes & Yes & Yes \\
\hline Firm Cluster & & Yes & Yes & Yes & Yes & Yes & Yes \\
\hline
\end{tabular}

Note: This table presents regression results for the tests that examine the association between IIQ and EIQ. Panel A, columns 1 and 2 (3 and 4) [5 and 6] report coefficients for an OLS regressions based on Equation (1) for EIQ_Error (EIQ_Disp) [EIQ_IDVOL]. EIQ_Error is the average of absolute analysts' forecast errors in the year in which Tax Risk measure is calculated, multiplied by (-1). EIQ_Disp is the average of the standard deviation of analysts' annual earnings forecasts in the year in which Tax Risk measure is calculated, multiplied by (-1). EIQ_IDVOL is the standard deviation of residuals from firmspecific regressions of daily returns on daily values of the Fama-French (1993) three factors plus the momentum factor (Carhartt 1997; Campbell and Taksler 2003) over years $t+1$ to $t+5$, multiplied by (-100). EIQ_Error and EIQ_Disp are winsorized at the 99th percentiles. All other continuous variables are winsorized at the 1st and 99th percentiles. All regressions are estimated with industry and year fixed. I report heteroscedasticity-robust standard errors clustered by firm in parentheses. I define variables in Appendix A. Statistical significance at the $10 \%, 5 \%$ and $1 \%$ level is denoted by *, **, and ***, respectively. I use one-tailed tests when a sign is predicted and two-tailed otherwise. 
Table 5

Impact of Tax Risk on the Association between IIQ and EIQ (Hypothesis 1)

Panel A: Continuous measure and Highest Quintile for Tax Risk

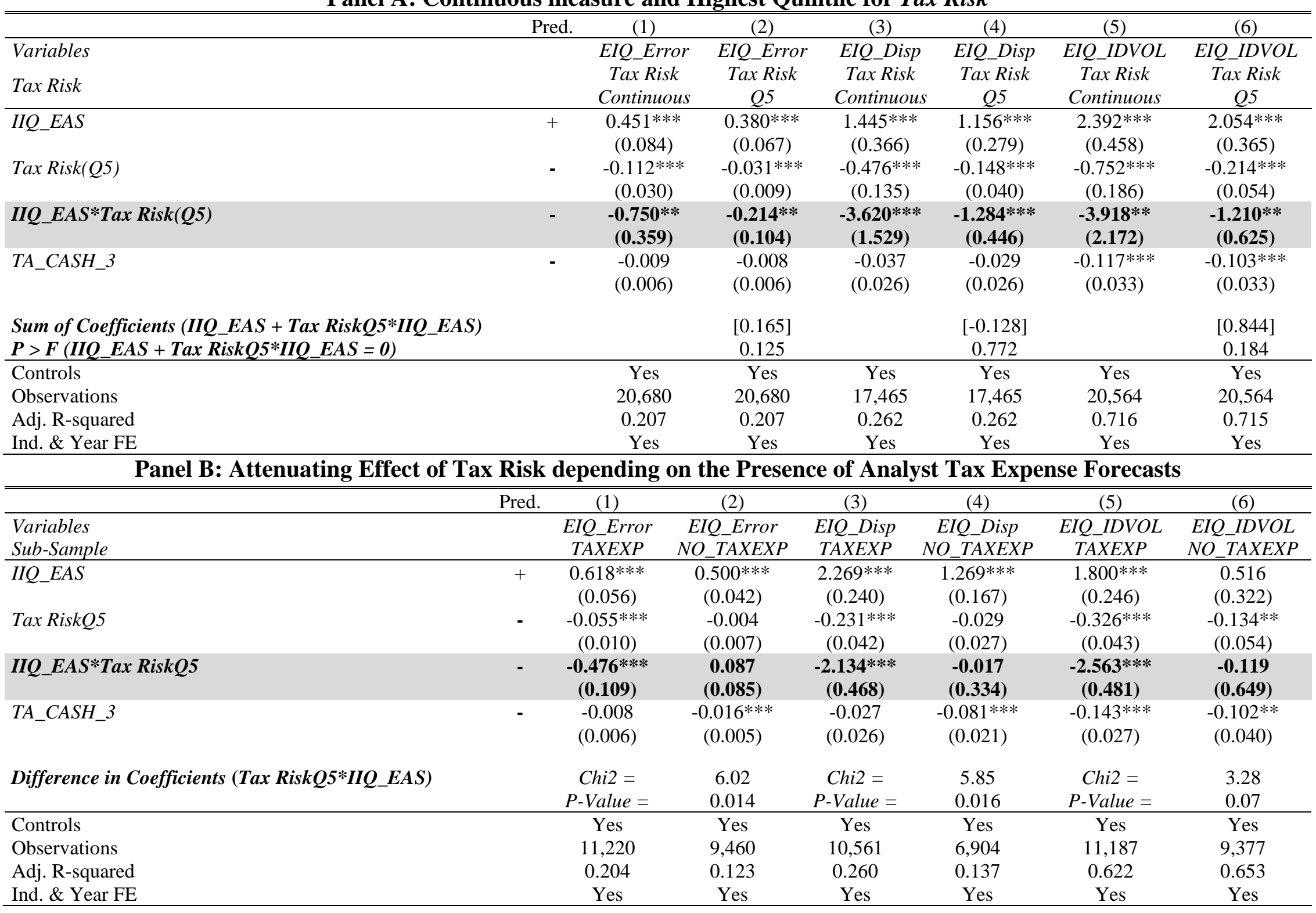


Table 5 (continued)

Panel C: Attenuating Effect of Tax Risk depending on IRS scrutiny

\begin{tabular}{|c|c|c|c|c|c|c|c|}
\hline & Pred. & (1) & (2) & (3) & (4) & (5) & (6) \\
\hline Variables & & EIQ_Error & EIQ_Error & EIQ_Disp & EIQ_Disp & EIQ_IDVOL & $E I Q \_I D V O L$ \\
\hline Sub-Sample & & $\begin{array}{c}\text { CIC Score } \\
\text { Low }\end{array}$ & $\begin{array}{c}\text { CIC Score } \\
\text { High }\end{array}$ & $\begin{array}{c}\text { CIC Score } \\
\text { Low }\end{array}$ & $\begin{array}{c}\text { CIC Score } \\
\text { High }\end{array}$ & $\begin{array}{c}\text { CIC Score } \\
\text { Low }\end{array}$ & $\begin{array}{c}\text { CIC Score } \\
\text { High }\end{array}$ \\
\hline$I I Q \_E A S$ & + & $\begin{array}{l}0.176 * \\
(0.098)\end{array}$ & $\begin{array}{c}0.462 * * \\
(0.206)\end{array}$ & $\begin{array}{c}0.335 \\
(0.339)\end{array}$ & $\begin{array}{c}1.882 * * \\
(0.828)\end{array}$ & $\begin{array}{c}4.074 * * * \\
(0.826)\end{array}$ & $\begin{array}{c}2.185 * * * \\
(0.581)\end{array}$ \\
\hline Tax RiskQ5 & - & $\begin{array}{c}0.001 \\
(0.017)\end{array}$ & $\begin{array}{c}-0.072 * * \\
(0.030)\end{array}$ & $\begin{array}{l}-0.036 \\
(0.063)\end{array}$ & $\begin{array}{c}-0.339 * * \\
(0.134)\end{array}$ & $\begin{array}{l}-0.134 \\
(0.085)\end{array}$ & $\begin{array}{c}-0.447 * * * \\
(0.125)\end{array}$ \\
\hline IIQ_EAS*Tax RiskQ5 & - & $\begin{array}{c}0.103 \\
(0.192)\end{array}$ & $\begin{array}{c}-0.645 * * \\
(0.350)\end{array}$ & $\begin{array}{c}-0.204 \\
(0.692)\end{array}$ & $\begin{array}{c}-3.364 * * \\
(1.537)\end{array}$ & $\begin{array}{c}-0.018 \\
(1.035)\end{array}$ & $\begin{array}{c}-3.835 * * * \\
(1.347)\end{array}$ \\
\hline$T A \_C A S H \_3$ & - & $\begin{array}{l}-0.007 \\
(0.014)\end{array}$ & $\begin{array}{l}-0.016 \\
(0.019)\end{array}$ & $\begin{array}{l}-0.011 \\
(0.049)\end{array}$ & $\begin{array}{l}-0.061 \\
(0.082)\end{array}$ & $\begin{array}{c}-0.357 * * * \\
(0.064)\end{array}$ & $\begin{array}{l}-0.087 \\
(0.071)\end{array}$ \\
\hline Difference in Coefficients (Tax RiskQ5*IIQ_EAS) & & $\begin{array}{c}\text { Chi2 = } \\
\text { P-Value = }\end{array}$ & $\begin{array}{c}3.57 \\
0.059\end{array}$ & $\begin{array}{c}\text { Chi2 = } \\
\text { P-Value = }\end{array}$ & $\begin{array}{c}3.58 \\
0.059\end{array}$ & $\begin{array}{c}\text { Chi2 = } \\
\text { P-Value = }\end{array}$ & $\begin{array}{c}5.29 \\
0.021 \\
\end{array}$ \\
\hline $\begin{array}{l}\text { Controls } \\
\text { Observations } \\
\text { Adj. R-squared } \\
\text { Ind. \& Year FE } \\
\text { Firm Cluster }\end{array}$ & & $\begin{array}{c}\text { Yes } \\
4,058 \\
0.143 \\
\text { Yes } \\
\text { Yes }\end{array}$ & $\begin{array}{c}\text { Yes } \\
4,039 \\
0.275 \\
\text { Yes } \\
\text { Yes }\end{array}$ & $\begin{array}{c}\text { Yes } \\
3,544 \\
0.160 \\
\text { Yes } \\
\text { Yes }\end{array}$ & $\begin{array}{c}\text { Yes } \\
3,806 \\
0.346 \\
\text { Yes } \\
\text { Yes }\end{array}$ & $\begin{array}{l}\text { Yes } \\
4,032 \\
0.664 \\
\text { Yes } \\
\text { Yes }\end{array}$ & $\begin{array}{c}\text { Yes } \\
4,043 \\
0.631 \\
\text { Yes } \\
\text { Yes }\end{array}$ \\
\hline $\begin{array}{l}\text { Note: This table presents regression results for the tests that exar } \\
\text { regressions based on Equation (2) using a continuous of tax risk } \\
\text { zero otherwise (Tax RiskQ5). Panel B presents results for firm-ye } \\
\text { (NO TAXEXP). Panel C presents results for firm-year observation } \\
\text { (CIC Score). CIC Score equals the probability that a firm is part } \\
\text { information presented in the IRS Internal Revenue Manual to asse } \\
\text { is the average of absolute analysts' forecast errors in the year in } \\
\text { analysts' annual earnings forecasts in the year in which Tax Rish } \\
\text { regressions of daily returns on daily values of the Fama-French ( } \\
\text { multiplied by (-100). Tax Risk is the standard deviation of the firn } \\
\text { regressions are estimated with year and industry-fixed effects. I r } \\
\text { A. Statistical significance at the } 10 \%, 5 \% \text { and } 1 \% \text { level is denoted }\end{array}$ & $\begin{array}{l}\text { whic } \\
\text { he IRS } \\
\text { e likel } \\
\text { ch } T a x \\
\text { asure i } \\
\text { three } \\
\text { ture a } \\
\text { heter }\end{array}$ & $\begin{array}{l}\text { nuating effect } \\
\text { dd an indicator } \\
\text { fns where analy } \\
\text { firms are below } \\
\text { Coordinated In } \\
\text { ood of IRS aud } \\
\text { Risk measure is } \\
\text { calculated, mu } \\
\text { actors plus the } \\
\text { nual industry- a } \\
\text { cedasticity-rob } \\
\text { d***, respectiv }\end{array}$ & $\begin{array}{l}\text { tax risk on the } \\
\text { ariable equal to } \\
\text { ts provide tax } \\
\text { (Low) and abo } \\
\text { ustry Case pro } \\
\text { based on obser } \\
\text { calculated, mul } \\
\text { plied by (-1). } \\
\text { omentum factc } \\
\text { d size-adjusted } \\
\text { t standard erro } \\
\text { ly. I use one-ta }\end{array}$ & $\begin{array}{l}\text { (High) the me } \\
\text { am (Ayers et } \\
\text { ble firm size } \\
\text { lied by }(-1) \text {. } \\
\text { Q_IDVOL is } \\
\text { Carhartt } 199 \\
\text { sh effective t } \\
\text { clustered by } \mathrm{f} \\
\text { d tests when }\end{array}$ & $\begin{array}{l}\text { TAXEXP) a } \\
\text { an probabili } \\
\text { 2019). The } \\
\text { loperationa } \\
\text { Q_Disp is th } \\
\text { standard de } \\
\text { Campbell an } \\
\text { rates (TA_C } \\
\text { in parenth }\end{array}$ & $\begin{array}{l}\text { do not provide } \\
\text { f being under } \\
\text { asure uses a po } \\
\text { mplexity charac } \\
\text { tverage of the s } \\
\text { tion of residual } \\
\text { aksler } 2003 \text { ) or } \\
\text { H_l) over the p } \\
\text { and define varial } \\
\text { and two-tailed }\end{array}$ & $\begin{array}{l}\text { s results for OLS } \\
\text { of Tax Risk, and } \\
\text { expense forecasts } \\
\text { tinuous IRS audit } \\
\text { system based on } \\
\text { istics. EIQ_Error } \\
\text { dard deviation of } \\
\text { rom firm-specific } \\
\text { years } t+1 \text { to } t+5 \text {, } \\
\text { od } t+1 \text { to } t+5 \text {. All } \\
\text { s in the Appendix } \\
\text { lerwise. }\end{array}$ \\
\hline
\end{tabular}


Table 6

FIN 48 as a Shock to Tax Risk

\begin{tabular}{|c|c|c|c|c|c|c|c|}
\hline Variables & $\begin{array}{l}\text { Pred. } \\
\text { Sign }\end{array}$ & $\begin{array}{c}\text { (1) } \\
\text { EIQ_Error }\end{array}$ & $\begin{array}{c}(2) \\
\text { EIQ_Error }\end{array}$ & $\begin{array}{c}(3) \\
E I Q \_D i s p\end{array}$ & $\begin{array}{c}(4) \\
E I Q \_D i s p\end{array}$ & $E I Q \_I D V O L$ & $\begin{array}{c}(6) \\
E I Q \_I D V O L\end{array}$ \\
\hline & & $\begin{array}{l}\text { All firms } \\
\text { UTB } 2007\end{array}$ & $\begin{array}{c}\text { Firms } \\
\text { UTB Q5 }\end{array}$ & $\begin{array}{l}\text { All firms } \\
\text { UTB } 2007\end{array}$ & $\begin{array}{c}\text { Firms } \\
\text { UTB Q5 }\end{array}$ & $\begin{array}{l}\text { All firms } \\
\text { UTB } 2007\end{array}$ & $\begin{array}{c}\text { Firms } \\
\text { UTB Q5 }\end{array}$ \\
\hline INTERCEPT & & $\begin{array}{c}0.105 * * * \\
(0.031)\end{array}$ & $\begin{array}{c}0.145 * * * \\
(0.048)\end{array}$ & $\begin{array}{c}0.597 * * * \\
(0.117)\end{array}$ & $\begin{array}{c}0.740 * * * \\
(0.195)\end{array}$ & $\begin{array}{c}-2.758 * * * \\
(0.150)\end{array}$ & $\begin{array}{c}-0.026 * * * \\
(0.003)\end{array}$ \\
\hline$I I Q \_E A S$ & + & $\begin{array}{c}0.519 * * * \\
(0.171)\end{array}$ & $\begin{array}{c}0.448 \\
(0.389)\end{array}$ & $\begin{array}{c}1.457 * * \\
(0.650)\end{array}$ & $\begin{array}{c}1.686 \\
(1.588)\end{array}$ & $\begin{array}{c}3.601 * * * \\
(0.706)\end{array}$ & $\begin{array}{c}0.036 * * * \\
(0.012)\end{array}$ \\
\hline POST & $?$ & $\begin{array}{c}-0.038 * * * \\
(0.013)\end{array}$ & $\begin{array}{c}-0.048 * * \\
(0.019)\end{array}$ & $\begin{array}{c}-0.208 * * * \\
(0.056)\end{array}$ & $\begin{array}{c}-0.282 * * * \\
(0.084)\end{array}$ & $\begin{array}{c}0.345^{* * *} * \\
(0.060)\end{array}$ & $\begin{array}{c}0.003 * * * \\
(0.001)\end{array}$ \\
\hline$I I Q \_E A S * P O S T$ & - & $\begin{array}{c}-0.262 * * \\
(0.155)\end{array}$ & $\begin{array}{c}-0.339 * \\
(0.248)\end{array}$ & $\begin{array}{c}-1.521 * * * \\
(0.618)\end{array}$ & $\begin{array}{c}-2.386 * * * \\
(0.982)\end{array}$ & $\begin{array}{c}-0.797 \\
(0.726)\end{array}$ & $\begin{array}{c}0.002 \\
(0.012)\end{array}$ \\
\hline TA_CASH_3 & - & $\begin{array}{c}-0.004 \\
(0.016) \\
\end{array}$ & $\begin{array}{l}-0.028 \\
(0.024) \\
\end{array}$ & $\begin{array}{l}-0.023 \\
(0.067) \\
\end{array}$ & $\begin{array}{l}-0.099 \\
(0.115) \\
\end{array}$ & $\begin{array}{l}-0.122 * \\
(0.078)\end{array}$ & $\begin{array}{c}0.000 \\
(0.001) \\
\end{array}$ \\
\hline Controls & & Yes & Yes & Yes & Yes & Yes & Yes \\
\hline Observations & & 3,677 & 820 & 3,459 & 782 & 3,445 & 775 \\
\hline Adj. R-squared & & 0.216 & 0.197 & 0.281 & 0.247 & 0.605 & 0.710 \\
\hline Industry FE & & Yes & Yes & Yes & Yes & Yes & Yes \\
\hline Firm Cluster & & Yes & Yes & Yes & Yes & Yes & Yes \\
\hline
\end{tabular}

Note: This table presents regression results for the shock to tax risk around the FIN 48 adoption based on Equation (2). Columns (1), (3), and (5) include all firms with an opening UTB balance in 2007 (Gupta et al. 2014). Columns (2), (4), and (6) include firms that have an opening UTB/total assets ratio in 2007 that is in the highest quintile, and zero otherwise (Gupta, Mills, and Towery 2014). POST is an indicator variable equal to one in the post-FIN 48 period (2007 to 2009) and zero in the pre-FIN 48 period (2004 to 2006). EIQ_Error is the average of absolute analysts' forecast errors in the year in which Tax Risk measure is calculated, multiplied by (-1). EIQ_Disp is the average of the standard deviation of analysts' annual earnings forecasts in the year in which Tax Risk measure is calculated, multiplied by (-1). EIQ_IDVOL is the standard deviation of residuals from firm-specific regressions of daily returns on daily values of the Fama-French (1993) three factors plus the momentum factor (Carhartt 1997; Campbell and Taksler 2003) over years $t+1$ to $t+5$, multiplied by (-100). EIQ_Error and EIQ_Disp are winsorized at the 99th percentiles. IIQ_EAS is the earnings announcement speed in days scaled by 365 and multiplied by (-1). All regressions are estimated with industry-fixed effects. I report heteroscedasticity-robust standard errors clustered by firm in parentheses. I define variables in the Appendix A. Statistical significance at the $10 \%, 5 \%$ and $1 \%$ level is denoted by $*, * *$, and $* * *$, respectively. I use one-tailed tests when a sign is predicted and two-tailed otherwise. 


\section{Table 7}

\section{Drivers Affecting the Association between IIQ and EIQ Panel A: Relation of IIQ and Tax Accrual Quality}

\begin{tabular}{|c|c|c|c|c|c|}
\hline & $\begin{array}{l}\text { Pred. } \\
\text { Sign }\end{array}$ & (1) & (2) & (3) & (4) \\
\hline Variables & & \multicolumn{2}{|c|}{$D V=\operatorname{Tax} A Q$} & \multicolumn{2}{|c|}{$D V=T a x A Q \_F F 17$} \\
\hline Tax Risk & & $\begin{array}{c}\text { Tax Risk } \\
\text { Continuous }\end{array}$ & $\begin{array}{c}\text { Tax Risk } \\
Q 5\end{array}$ & $\begin{array}{c}\text { Tax Risk } \\
\text { Continuous }\end{array}$ & $\begin{array}{c}\text { Tax Risk } \\
\text { Q5 }\end{array}$ \\
\hline$I I Q \_E A S$ & + & $\begin{array}{c}0.015^{* *} \\
(0.007)\end{array}$ & $\begin{array}{c}0.011 * * \\
(0.006)\end{array}$ & $\begin{array}{c}0.019 * * * \\
(0.007)\end{array}$ & $\begin{array}{c}0.014 * * * \\
(0.006)\end{array}$ \\
\hline Tax Risk(Q5) & - & $\begin{array}{l}-0.000 \\
(0.001)\end{array}$ & $\begin{array}{c}0.000 \\
(0.000)\end{array}$ & $\begin{array}{c}0.000 \\
(0.001)\end{array}$ & $\begin{array}{c}0.000 \\
(0.000)\end{array}$ \\
\hline$I I Q \_E A S * T a x \operatorname{Risk}(Q 5)$ & - & $\begin{array}{l}-0.042 * \\
(0.030)\end{array}$ & $\begin{array}{c}-0.014 * \\
(0.009)\end{array}$ & $\begin{array}{c}-0.050 * * \\
(0.030)\end{array}$ & $\begin{array}{c}-0.016 * * \\
(0.009)\end{array}$ \\
\hline TA_CASH_3 & - & $\begin{array}{c}-0.002 * * \\
(0.001) \\
\end{array}$ & $\begin{array}{c}-0.002^{* *} * \\
(0.001)\end{array}$ & $\begin{array}{c}-0.002 * * * \\
(0.001)\end{array}$ & $\begin{array}{c}-0.002 * * * \\
(0.001) \\
\end{array}$ \\
\hline Controls & & Yes & Yes & Yes & Yes \\
\hline Observations & & 5,969 & 5,969 & 5,969 & 5,969 \\
\hline Adj. R-squared & & 0.236 & 0.236 & 0.149 & 0.149 \\
\hline Ind. \& Year FE & & Yes & Yes & Yes & Yes \\
\hline Firm Cluster & & Yes & Yes & Yes & Yes \\
\hline
\end{tabular}

\section{Panel B: Relation of IIQ and Disclosure}

\begin{tabular}{|c|c|c|c|c|c|c|c|}
\hline & $\begin{array}{l}\text { Pred. } \\
\text { Sign }\end{array}$ & (1) & (2) & (3) & (4) & (5) & (6) \\
\hline Variables & & \multicolumn{2}{|c|}{$D V=L_{0} \_10 K W o r d$} & \multicolumn{2}{|c|}{$D V=$ Log_FNWord } & \multicolumn{2}{|c|}{$D V=\log _{-} M D A W o r d$} \\
\hline Tax Risk & & Continuous & $Q 5$ & Continuous & $Q 5$ & Continuous & $Q 5$ \\
\hline$I I Q \_E A S$ & $?$ & $\begin{array}{c}-1.604 * * * \\
(0.530)\end{array}$ & $\begin{array}{c}-1.781 * * * \\
(0.411)\end{array}$ & $\begin{array}{c}-1.700 * * * \\
(0.475)\end{array}$ & $\begin{array}{c}-1.636 * * * \\
(0.365)\end{array}$ & $\begin{array}{l}-1.343 \\
(1.112)\end{array}$ & $\begin{array}{c}-0.873 \\
(0.825)\end{array}$ \\
\hline Tax Risk(Q5) & + & $\begin{array}{c}0.063 \\
(0.181)\end{array}$ & $\begin{array}{c}0.044 \\
(0.051)\end{array}$ & $\begin{array}{c}0.028 \\
(0.176)\end{array}$ & $\begin{array}{c}0.006 \\
(0.051)\end{array}$ & $\begin{array}{c}0.242 \\
(0.412)\end{array}$ & $\begin{array}{c}-0.052 \\
(0.115)\end{array}$ \\
\hline IIQ_EAS*Tax Risk(Q5) & $?$ & $\begin{array}{l}-0.517 \\
(2.013)\end{array}$ & $\begin{array}{c}0.329 \\
(0.565)\end{array}$ & $\begin{array}{c}0.743 \\
(1.959)\end{array}$ & $\begin{array}{c}0.247 \\
(0.572)\end{array}$ & $\begin{array}{c}2.615 \\
(4.639)\end{array}$ & $\begin{array}{l}-0.341 \\
(1.272)\end{array}$ \\
\hline TA_CASH_3 & + & $\begin{array}{c}0.152 * * * \\
(0.033)\end{array}$ & $\begin{array}{c}0.145^{* * *} * \\
(0.033)\end{array}$ & $\begin{array}{c}0.141 * * * \\
(0.031)\end{array}$ & $\begin{array}{c}0.141 * * * \\
(0.032)\end{array}$ & $\begin{array}{c}0.135 * * \\
(0.078) \\
\end{array}$ & $\begin{array}{c}0.132 * * \\
(0.078) \\
\end{array}$ \\
\hline Controls & & Yes & Yes & Yes & Yes & Yes & Yes \\
\hline Observations & & 12,090 & 12,090 & 11,233 & 11,233 & 9,079 & 9,079 \\
\hline Adj. R-squared & & 0.543 & 0.543 & 0.498 & 0.498 & 0.170 & 0.170 \\
\hline Ind. \& Year FE & & Yes & Yes & Yes & Yes & Yes & Yes \\
\hline Firm Cluster & & Yes & Yes & Yes & Yes & Yes & Yes \\
\hline
\end{tabular}

Note: This table presents regression results for the drivers that affect the association between IIQ and EIQ. Panels A and B present results for OLS regressions based on Equation (2) using an indicator variable equal to one if a firm-year observation is in the fifth quintile of Tax Risk, and zero otherwise (Tax RiskQ5). TaxAQ is the standard deviation of the residuals from firm-specific estimates of

$T a x A C C_{i, t}=b_{0}+b_{1} C T P_{i, t-1}+b_{2} C T P_{i, t}+b_{3} C T P_{i, t+1}+b_{4} \Delta D T L \_L T_{i, t}+b_{5} \Delta D T A_{-} L T_{i, t}+e_{i, t}[3]$,

multiplied by -1 , so larger values indicate better tax accrual quality (Choudhary; Koester, and Shevlin 2016). TaxAQ_FF17 is the industry- and size-adjusted measure of TaxAQ. Log_10KWord, Log_FNWord, Log_MDAWord are the logarithm of the word count for references to taxes (e.g., 'Income Taxes', 'Tax') in 10-K report, tax footnotes, and MD\&A, respectively. Tax Risk is the standard deviation of the firm's future annual industry- and size-adjusted cash effective tax rates $\left(T A \_C A S H \_1\right)$ over the period $\mathrm{t}+1$ to $\mathrm{t}+5$. All regressions are estimated with year and industry-fixed effects. I report heteroscedasticity-robust standard errors clustered by firm in parentheses. I define variables in the Appendix A. Statistical significance at the $10 \%, 5 \%$ and $1 \%$ level is denoted by *,**, and $* * *$, respectively. I use one-tailed tests when a sign is predicted and two-tailed otherwise. 
Table 8

Supplemental Tests

Panel A: Analyst Tax Expense Forecast Error and Tax Risk

\begin{tabular}{|c|c|c|c|c|c|}
\hline & $\begin{array}{l}\text { Pred. } \\
\text { Sign }\end{array}$ & (1) & (2) & (3) & (4) \\
\hline Variables & & EIQ_Error & EIQ_Error & EIQ_Disp & EIQ_Disp \\
\hline Sub-Sample & & $\begin{array}{c}T A X E X P_{-} E r \\
<0\end{array}$ & $\begin{array}{c}\text { TAXEXP_Er } \\
>0\end{array}$ & $\begin{array}{c}\text { TAXEXP_Er } \\
<0\end{array}$ & $\begin{array}{c}\text { TAXEXP_Er } \\
>0\end{array}$ \\
\hline$I I Q \_E A S$ & + & $\begin{array}{c}0.369 * * * \\
(0.069)\end{array}$ & $\begin{array}{c}0.425 * * * \\
(0.104)\end{array}$ & $\begin{array}{c}0.953 * * * \\
(0.282)\end{array}$ & $\begin{array}{c}1.638^{* * * *} \\
(0.420)\end{array}$ \\
\hline Tax RiskQ5 & - & $\begin{array}{c}-0.024 * * * \\
(0.010)\end{array}$ & $\begin{array}{c}-0.048 * * * \\
(0.016)\end{array}$ & $\begin{array}{c}-0.109 * * * \\
(0.044)\end{array}$ & $\begin{array}{c}-0.238 * * * \\
(0.068)\end{array}$ \\
\hline IIQ_EAS*Tax RiskQ5 & - & $\begin{array}{c}-0.169 * \\
(0.125)\end{array}$ & $\begin{array}{c}-0.367 * * \\
(0.170)\end{array}$ & $\begin{array}{c}-0.990 * * \\
(0.513)\end{array}$ & $\begin{array}{c}-2.094 * * * \\
(0.726)\end{array}$ \\
\hline TA_CASH_3 & - & $\begin{array}{l}-0.010^{*} \\
(0.006) \\
\end{array}$ & $\begin{array}{l}-0.006 \\
(0.011)\end{array}$ & $\begin{array}{r}-0.036^{*} \\
(0.027) \\
\end{array}$ & $\begin{array}{l}-0.038 \\
(0.045)\end{array}$ \\
\hline Controls & & Yes & Yes & Yes & Yes \\
\hline Observations & & 14,460 & 6,206 & 11,603 & 5,850 \\
\hline Adj. R-squared & & 0.195 & 0.228 & 0.254 & 0.272 \\
\hline Ind. \& Year FE & & Yes & Yes & Yes & Yes \\
\hline Firm Cluster & & Yes & Yes & Yes & Yes \\
\hline
\end{tabular}

Panel B: Analyst Forecast Error and Tax Risk

\begin{tabular}{|c|c|c|c|c|c|}
\hline & $\begin{array}{l}\text { Pred. } \\
\text { Sign }\end{array}$ & (1) & (2) & (3) & (4) \\
\hline Variables & & EIQ_Error & EIQ_Error & EIQ_Disp & EIQ_Disp \\
\hline Sub-Sample & & $\begin{array}{c}A F \_E r \\
<0\end{array}$ & $\begin{array}{c}A F_{-} E r \\
>0\end{array}$ & $\begin{array}{c}A F \_E r \\
<0\end{array}$ & $\begin{array}{c}A F \_E r \\
>0\end{array}$ \\
\hline$I I Q \_E A S$ & + & $\begin{array}{c}0.366^{* * * *} \\
(0.076)\end{array}$ & $\begin{array}{c}0.384 * * * \\
(0.084)\end{array}$ & $\begin{array}{c}1.192 * * * \\
(0.350)\end{array}$ & $\begin{array}{c}1.082 * * * \\
(0.320)\end{array}$ \\
\hline Tax RiskQ5 & - & $\begin{array}{c}-0.030 * * \\
(0.014)\end{array}$ & $\begin{array}{c}-0.028 * * * \\
(0.011)\end{array}$ & $\begin{array}{c}-0.148 * * * \\
(0.063)\end{array}$ & $\begin{array}{c}-0.133 * * * \\
(0.046)\end{array}$ \\
\hline$I I Q \_E A S * T a x$ RiskQ5 & - & $\begin{array}{c}-0.207 * \\
(0.156)\end{array}$ & $\begin{array}{c}-0.203^{*} \\
(0.136)\end{array}$ & $\begin{array}{c}-1.237 * * \\
(0.700)\end{array}$ & $\begin{array}{c}-1.223 * * * \\
(0.517)\end{array}$ \\
\hline TA_CASH_3 & - & $\begin{array}{c}-0.014 * * \\
(0.007)\end{array}$ & $\begin{array}{l}-0.001 \\
(0.008)\end{array}$ & $\begin{array}{l}-0.036 \\
(0.033)\end{array}$ & $\begin{array}{l}-0.024 \\
(0.032)\end{array}$ \\
\hline Controls & & Yes & Yes & Yes & Yes \\
\hline Observations & & 10,677 & 10,003 & 9,107 & 8,358 \\
\hline Adj. R-squared & & 0.209 & 0.215 & 0.271 & 0.265 \\
\hline Ind. \& Year FE & & Yes & Yes & Yes & Yes \\
\hline Firm Cluster & & Yes & Yes & Yes & Yes \\
\hline
\end{tabular}


Table 8 (continued)

Panel C: Horse Race between ETR Level and Tax Risk

\begin{tabular}{lcccc}
\hline \hline & Pred. & $(1)$ & $(2)$ & $(3)$ \\
\hline Variables & Sign & EIQ_Error & EIQ_Disp & EIQ_IDVOL \\
\hline IIQ_EAS & & $0.342^{* * *}$ & $1.022^{* * *}$ & $2.177^{* * *}$ \\
& + & $(0.071)$ & $(0.305)$ & $(0.392)$ \\
Tax RiskQ5 & - & $-0.030^{* * *}$ & $-0.146^{* * *}$ & $-0.219^{* * *}$ \\
& & $(0.009)$ & $(0.040)$ & $(0.054)$ \\
IIQ_EAS*Tax RiskQ5 & - & $\mathbf{- 0 . 2 0 4 * *}$ & $\mathbf{- 1 . 2 4 9 * * *}$ & $\mathbf{- 1 . 2 4 8} * *$ \\
& & $\mathbf{( 0 . 1 0 4 )}$ & $\mathbf{( 0 . 4 4 7 )}$ & $\mathbf{( 0 . 6 2 4 )}$ \\
TA_CASH_3_Q5 & - & 0.005 & 0.021 & $-0.166^{* * *}$ \\
& & $(0.009)$ & $(0.036)$ & $(0.049)$ \\
IIQ_EAS*TA_CASH_3_Q5 & - & $\mathbf{0 . 1 5 0}$ & $\mathbf{0 . 5 4 1}$ & $\mathbf{- 0 . 7 0 7}$ \\
& & $\mathbf{( 0 . 1 0 8 )}$ & $\mathbf{( 0 . 4 1 2 )}$ & $\mathbf{( 0 . 5 7 1 )}$ \\
\hline Controls & & Yes & Yes & Yes \\
Observations & & 20,680 & 17,465 & 20,564 \\
Adj. R-squared & & 0.207 & 0.262 & 0.717 \\
Ind. \& Year FE & & Yes & Yes & Yes \\
Firm Cluster & & Yes & Yes & Yes \\
\hline
\end{tabular}

Panel D: Horse Race between Business-Related Proprietary Costs and Tax Risk

\begin{tabular}{lcccc}
\hline \hline & Pred. & $(1)$ & $(2)$ & $(3)$ \\
\hline Variables & Sign & EIQ_Error & EIQ_Disp & EIQ_IDVOL \\
\hline IIQ_EAS & & $0.536 * * *$ & $1.647 * * *$ & $2.364 * * *$ \\
& + & $(0.088)$ & $(0.377)$ & $(0.473)$ \\
Tax RiskQ5 & - & $-0.116^{* * *}$ & $-0.477 * * *$ & $-0.778^{* * *}$ \\
& - & $(0.030)$ & $(0.134)$ & $(0.186)$ \\
IIQ_EAS*Tax RiskQ5 & - & $\mathbf{- 0 . 7 8 9 * *}$ & $\mathbf{- 3 . 6 4 0 * * *}$ & $\mathbf{- 4 . 0 6 6 * *}$ \\
& - & $\mathbf{( 0 . 3 5 7 )}$ & $\mathbf{( 1 . 5 2 5 )}$ & $(\mathbf{2 . 1 6 1 )}$ \\
I_ROAQ5 & - & $-0.039 * * *$ & $-0.154 * * *$ & $0.154 * * *$ \\
& - & $(0.009)$ & $(0.039)$ & $(0.049)$ \\
IIQ_EAS*I_ROAQ5 & $-\mathbf{0 . 3 5 4 * * *}$ & $\mathbf{- 1 . 0 8 2 * * *}$ & $\mathbf{0 . 8 8 8}$ \\
& & $\mathbf{( 0 . 1 0 5 )}$ & $\mathbf{( 0 . 4 3 8 )}$ & $\mathbf{( 0 . 5 8 2 )}$ \\
\hline Controls & & Yes & Yes & Yes \\
Observations & & 20,680 & 17,465 & 20,564 \\
Adj. R-squared & & 0.209 & 0.262 & 0.714 \\
Ind. \& Year FE & & Yes & Yes & Yes \\
Firm Cluster & & Yes & Yes & Yes \\
\hline
\end{tabular}


Table 8 (continued)

Panel E: Horse Race between other Business-Related Volatility Measure and Tax Risk

\begin{tabular}{|c|c|c|c|c|}
\hline & $\begin{array}{l}\text { Pred. } \\
\text { Sign }\end{array}$ & (1) & (2) & (3) \\
\hline Variables & & EIQ_Error & EIQ_Disp & $E I Q \_I D V O L$ \\
\hline$\overline{I I Q \_E A S}$ & + & $\begin{array}{c}0.420 * * * \\
(0.073)\end{array}$ & $\begin{array}{c}1.377 * * * \\
(0.297)\end{array}$ & $\begin{array}{c}1.856 * * * \\
(0.376)\end{array}$ \\
\hline Tax RiskQ5 & - & $\begin{array}{c}-0.030 * * * \\
(0.009)\end{array}$ & $\begin{array}{c}-0.145 * * * \\
(0.040)\end{array}$ & $\begin{array}{c}-0.213 * * * \\
(0.054)\end{array}$ \\
\hline IIQ_EAS*Tax RiskQ5 & - & $\begin{array}{c}-0.212 * * \\
(0.104)\end{array}$ & $\begin{array}{c}-1.252 * * * * \\
(0.447)\end{array}$ & $\begin{array}{c}-1.181 * * \\
(0.625)\end{array}$ \\
\hline Std. Dev. of PTBIQ5 & - & $\begin{array}{c}-0.012 * \\
(0.009)\end{array}$ & $\begin{array}{c}-0.080 * * \\
(0.038)\end{array}$ & $\begin{array}{l}-0.003 \\
(0.060)\end{array}$ \\
\hline IIQ_EAS*Std. Dev. of PTBIQ5 & $?$ & $\begin{array}{c}-0.183 * * \\
(0.109) \\
\end{array}$ & $\begin{array}{c}-1.020 * * \\
(0.441) \\
\end{array}$ & $\begin{array}{c}0.882 \\
(0.668) \\
\end{array}$ \\
\hline Controls & & Yes & Yes & Yes \\
\hline Observations & & 20,680 & 17,465 & 20,564 \\
\hline Adj. R-squared & & 0.207 & 0.262 & 0.716 \\
\hline Ind. \& Year FE & & Yes & Yes & Yes \\
\hline Firm Cluster & & Yes & Yes & Yes \\
\hline
\end{tabular}

Note: This table presents regression results for supplemental tests using Equation (2). Panel A presents results for bifurcating the sample into observations that are below or above the raw median estimate is below the actual forecast error for tax expense (TAXEXP_Er). TAXEXP_Er is the Analyst Tax Expense Forecast Error, measured as the average analysts' (raw) forecast errors for the I/B/E/S-based tax expense measure $(T A X E X P)$ in the year in which the Tax Risk measure is calculated. Columns (1) and (3) present results for firm-years in which the raw median estimate is below the actual forecast error for tax expense $\left(T A X E X P \_E r<\right.$ 0 ). Columns (2) and (4) present results for firm-years in which the raw median estimate is above the actual forecast error for tax expense $\left(T A X E X P \_E r>0\right)$. Panel B presents results for bifurcating the sample into observations that are below or above the raw median estimate is below the actual earnings forecast error $\left(A F \_E r\right) . A F \_E r$ is the Analyst Forecast Error, measured as the average analysts' (raw) forecast errors for the I/B/E/S-based earnings in the year in which the Tax Risk measure is calculated. Columns (1) and (3) present results for firm-years in which the raw median estimate is below the actual forecast error $\left(A F_{-} E r<0\right)$. Columns (2) and (4) present results for firm-years in which the raw median estimate is above the actual forecast error $\left(A F_{-} E r>0\right)$. Panel $\mathrm{C}$ presents results for the "horse race" test that adds the interaction of IIQ_EAS*TA_CASH_3_Q5 to Equation (2). Panel D presents results for the "horse race" test that adds the interaction of IIQ_EAS*I_ROAQ5 to Equation (2). Panel E presents results for the "horse race" test that adds the interaction of IIQ_EAS*Std. Dev. of PTBIQ5 to Equation (2). IIQ_EAS is the earnings announcement speed in days scaled by 365 and multiplied by (-1). Tax Risk is the standard deviation of the firm's future annual cash effective tax rates (TA_CASH_l) over the period $t+1$ to $t+5$. I_ROA is the industry- and size-adjusted return on assets (calculated as operating income before depreciation divided by average total assets) to measure abnormal segment profits (Berger and Hann 2007). Std. Dev. of Sales is the standard deviation of annual sales over the period $t+1$ to $t+5$. All regressions are estimated with year and industry-fixed effects. I report heteroscedasticity-robust standard errors clustered by firm in parentheses. I define variables in the Appendix A. Statistical significance at the $10 \%, 5 \%$ and $1 \%$ level is denoted by $*$, $*$, and $* * *$, respectively. I use one-tailed tests when a sign is predicted and two-tailed otherwise. 
Table A.1

Association of IIQ and EIQ (Baseline Tests)

Panel A: OLS specification

\begin{tabular}{|c|c|c|c|c|c|c|c|}
\hline Variables & $\begin{array}{l}\text { Pred. } \\
\text { Sign }\end{array}$ & $\begin{array}{c}(1) \\
\text { EIQ_Error }\end{array}$ & $\begin{array}{c}(2) \\
\text { EIQ_Error }\end{array}$ & $\begin{array}{c}(3) \\
\text { EIQ_Disp }\end{array}$ & $\begin{array}{c}(4) \\
E I Q \_D i s p\end{array}$ & $\begin{array}{c}(5) \\
E I Q \_I D V O L\end{array}$ & $\begin{array}{c}(6) \\
E I Q \_I D V O L\end{array}$ \\
\hline$I I Q \_M F A$ & + & $\begin{array}{c}1.228 * * * \\
(0.263)\end{array}$ & & $\begin{array}{c}\text { 5.478*** } \\
(1.173)\end{array}$ & & $\begin{array}{c}0.016 * * * \\
(0.006)\end{array}$ & \\
\hline$I I Q \_N o \_I C W$ & + & & $\begin{array}{c}0.026 * * * * \\
(0.008)\end{array}$ & & $\begin{array}{c}0.091 * * * \\
(0.030)\end{array}$ & & $\begin{array}{c}0.002 * * * \\
(0.000)\end{array}$ \\
\hline Size & & $\begin{array}{c}-0.011 * * * \\
(0.002)\end{array}$ & $\begin{array}{c}-0.024 * * * \\
(0.003)\end{array}$ & $\begin{array}{c}-0.062 * * * \\
(0.009)\end{array}$ & $\begin{array}{c}-0.125^{* * * *} \\
(0.012)\end{array}$ & $\begin{array}{c}0.002 * * * \\
(0.000)\end{array}$ & $\begin{array}{c}0.001 * * * \\
(0.000)\end{array}$ \\
\hline Leverage & & $\begin{array}{c}-0.036^{* * * *} \\
(0.011)\end{array}$ & $\begin{array}{l}-0.004 \\
(0.013)\end{array}$ & $\begin{array}{c}-0.106^{* *} \\
(0.045)\end{array}$ & $\begin{array}{c}0.029 \\
(0.058)\end{array}$ & $\begin{array}{c}-0.002 * * \\
(0.001)\end{array}$ & $\begin{array}{c}-0.003 * * \\
(0.001)\end{array}$ \\
\hline Loss & & $\begin{array}{c}0.008^{* *} \\
(0.003)\end{array}$ & $\begin{array}{l}-0.001 \\
(0.004)\end{array}$ & $\begin{array}{l}0.029^{*} \\
(0.015)\end{array}$ & $\begin{array}{l}-0.002 \\
(0.017)\end{array}$ & $\begin{array}{l}-0.000^{*} \\
(0.000)\end{array}$ & $\begin{array}{l}-0.000 \\
(0.000)\end{array}$ \\
\hline Foreign Income & & $\begin{array}{c}0.005 \\
(0.053)\end{array}$ & $\begin{array}{l}-0.036 \\
(0.067)\end{array}$ & $\begin{array}{l}-0.071 \\
(0.202)\end{array}$ & $\begin{array}{l}-0.385 \\
(0.315)\end{array}$ & $\begin{array}{c}0.002 \\
(0.003)\end{array}$ & $\begin{array}{c}0.002 \\
(0.002)\end{array}$ \\
\hline$M T B$ & & $\begin{array}{c}0.003 * * * \\
(0.001)\end{array}$ & $\begin{array}{c}0.004 * * * \\
(0.001)\end{array}$ & $\begin{array}{c}0.013 * * * \\
(0.002)\end{array}$ & $\begin{array}{c}0.019 * * * \\
(0.002)\end{array}$ & $\begin{array}{c}0.000 * * * \\
(0.000)\end{array}$ & $\begin{array}{c}0.000 * * * \\
(0.000)\end{array}$ \\
\hline Age & & $\begin{array}{l}-0.002 \\
(0.002)\end{array}$ & $\begin{array}{c}0.001 \\
(0.002)\end{array}$ & $\begin{array}{l}-0.004 \\
(0.009)\end{array}$ & $\begin{array}{c}0.013 \\
(0.009)\end{array}$ & $\begin{array}{c}0.001 * * * \\
(0.000)\end{array}$ & $\begin{array}{c}0.001 * * * \\
(0.000)\end{array}$ \\
\hline Analyst Follow. & & $\begin{array}{c}0.007 * * * \\
(0.002)\end{array}$ & $\begin{array}{c}0.022 * * * \\
(0.004)\end{array}$ & $\begin{array}{l}-0.008 \\
(0.010)\end{array}$ & $\begin{array}{c}0.011 \\
(0.011)\end{array}$ & $\begin{array}{c}0.000 \\
(0.000)\end{array}$ & $\begin{array}{l}0.000^{*} \\
(0.000)\end{array}$ \\
\hline Geo. Complexity & & $\begin{array}{l}-0.005 \\
(0.005)\end{array}$ & $\begin{array}{c}0.004 \\
(0.007)\end{array}$ & $\begin{array}{l}-0.017 \\
(0.022)\end{array}$ & $\begin{array}{c}0.021 \\
(0.029)\end{array}$ & $\begin{array}{l}-0.001 * \\
(0.000)\end{array}$ & $\begin{array}{c}-0.001 * * * \\
(0.000)\end{array}$ \\
\hline Std Dev. Sales & & $\begin{array}{l}-0.020 \\
(0.015)\end{array}$ & $\begin{array}{c}-0.065^{* * *} \\
(0.017)\end{array}$ & $\begin{array}{l}-0.079 \\
(0.064)\end{array}$ & $\begin{array}{c}-0.231^{* *} \\
(0.076)\end{array}$ & $\begin{array}{c}-0.003^{* * *} \\
(0.001)\end{array}$ & $\begin{array}{l}-0.001 \\
(0.001)\end{array}$ \\
\hline Restructure & & $\begin{array}{l}-0.001 \\
(0.004)\end{array}$ & $\begin{array}{c}0.014 * * \\
(0.005)\end{array}$ & $\begin{array}{c}0.001 \\
(0.015)\end{array}$ & $\begin{array}{c}0.060 * * \\
(0.020)\end{array}$ & $\begin{array}{l}-0.000 \\
(0.000)\end{array}$ & $\begin{array}{l}-0.000 \\
(0.000)\end{array}$ \\
\hline Inst. Owner. & & $\begin{array}{c}-0.030 * * * \\
(0.010)\end{array}$ & $\begin{array}{c}-0.033 * * \\
(0.010)\end{array}$ & $\begin{array}{c}-0.130 * * * \\
(0.041)\end{array}$ & $\begin{array}{c}-0.188^{* * *} \\
(0.041)\end{array}$ & $\begin{array}{c}0.003 * * * \\
(0.001)\end{array}$ & $\begin{array}{c}0.004 * * * \\
(0.001)\end{array}$ \\
\hline I_ROA & & $\begin{array}{l}-0.006 \\
(0.029)\end{array}$ & $\begin{array}{l}-0.028 \\
(0.023)\end{array}$ & $\begin{array}{l}-0.149 \\
(0.124)\end{array}$ & $\begin{array}{c}-0.324 * * * \\
(0.090)\end{array}$ & $\begin{array}{c}0.007 * * * \\
(0.002)\end{array}$ & $\begin{array}{c}0.009 * * * \\
(0.002)\end{array}$ \\
\hline$S D \_R e t$ & & $\begin{array}{c}-0.347 * * * \\
(0.067)\end{array}$ & $\begin{array}{c}-0.499 * * * \\
(0.049)\end{array}$ & $\begin{array}{c}-1.457 * * * \\
(0.264)\end{array}$ & $\begin{array}{c}-2.144 * * * \\
(0.234)\end{array}$ & $\begin{array}{c}-0.060 * * * \\
(0.004)\end{array}$ & $\begin{array}{c}-0.062 * * * \\
(0.006)\end{array}$ \\
\hline Std Dev. PTBI & & $\begin{array}{c}-0.148 * * * \\
(0.041)\end{array}$ & $\begin{array}{c}-0.245^{* * *} \\
(0.045)\end{array}$ & $\begin{array}{c}-0.659 * * * \\
(0.185)\end{array}$ & $\begin{array}{c}-1.027 * * * \\
(0.199)\end{array}$ & $\begin{array}{c}-0.039 * * * \\
(0.004)\end{array}$ & $\begin{array}{c}-0.038 * * * \\
(0.003)\end{array}$ \\
\hline Observations & & 4,372 & 10,029 & 3,995 & 9,405 & 4,360 & 10,010 \\
\hline Adj. R-squared & & 0.252 & 0.203 & 0.276 & 0.261 & 0.754 & 0.660 \\
\hline Ind. \& Year FE & & Yes & Yes & Yes & Yes & Yes & Yes \\
\hline Firm Cluster & & Yes & Yes & Yes & Yes & Yes & Yes \\
\hline
\end{tabular}


Table A.1 (continued) - Association of IIQ and EIQ (Baseline Tests)

Panel B: Changes Model

\begin{tabular}{|c|c|c|c|c|c|c|c|c|c|c|c|c|c|}
\hline Variables & $\begin{array}{l}\text { Pred. } \\
\text { Sign }\end{array}$ & $\begin{array}{c}(1) \\
\text { EIQ_Error }\end{array}$ & $\begin{array}{c}\text { (2) } \\
\text { EIQ_Error }\end{array}$ & $\begin{array}{c}\text { (3) } \\
\text { EIQ_Error }\end{array}$ & $\begin{array}{c}(4) \\
\text { EIQ_Error }\end{array}$ & $\begin{array}{c}\text { (5) } \\
\text { EIQ_Disp }\end{array}$ & $\begin{array}{c}\text { (6) } \\
\text { EIQ_Disp }\end{array}$ & $\begin{array}{c}\text { (7) } \\
\text { EIQ_Disp }\end{array}$ & $\begin{array}{c}(8) \\
\text { EIQ_Disp }\end{array}$ & $\begin{array}{c}(9) \\
E I Q \_I D V O L\end{array}$ & $\begin{array}{c}(10) \\
E I Q \_I D V O L\end{array}$ & $\begin{array}{c}(11) \\
E I Q \_I D V O L\end{array}$ & $\begin{array}{c}(12) \\
\text { EIQ_IDVOL }\end{array}$ \\
\hline$\triangle I I Q \_E A S$ & + & $\begin{array}{c}0.193 * * * \\
(0.064)\end{array}$ & & & & $\begin{array}{l}0.549 * * \\
(0.262)\end{array}$ & & & & $\begin{array}{c}0.360 * * \\
(0.192)\end{array}$ & & & \\
\hline$\triangle I I Q \_E A S \_F F 17$ & + & & $\begin{array}{c}0.175 * * * \\
(0.054)\end{array}$ & & & & $\begin{array}{l}0.467 * \\
(0.274)\end{array}$ & & & & $\begin{array}{l}0.314 * * \\
(0.148)\end{array}$ & & \\
\hline$\triangle I I Q \_M F A$ & + & & & $\begin{array}{c}0.630 * * * \\
(0.196)\end{array}$ & & & & $\begin{array}{c}2.700 * * * \\
(0.688)\end{array}$ & & & & $\begin{array}{l}\mathbf{0 . 3 5 0} * * * \\
(0.160)\end{array}$ & \\
\hline$\triangle I I Q \_N o \_I C W$ & + & & & & $\begin{array}{c}0.017 * * \\
(0.008)\end{array}$ & & & & $\begin{array}{c}\mathbf{0 . 0 5 1} \\
(\mathbf{0 . 0 3 7})\end{array}$ & & & & $\begin{array}{c}0.004 \\
(0.008)\end{array}$ \\
\hline$\triangle$ Size & & $\begin{array}{c}-0.021^{* * * *} \\
(0.005)\end{array}$ & $\begin{array}{c}-0.021 * * * \\
(0.005)\end{array}$ & $\begin{array}{l}-0.019 \\
(0.014)\end{array}$ & $\begin{array}{c}-0.034 * * \\
(0.011)\end{array}$ & $\begin{array}{c}-0.093 * * * \\
(0.024)\end{array}$ & $\begin{array}{c}-0.093 * * * \\
(0.024)\end{array}$ & $\begin{array}{l}-0.068 \\
(0.044)\end{array}$ & $\begin{array}{c}-0.125^{* *} \\
(0.047)\end{array}$ & $\begin{array}{l}0.042 * \\
(0.024)\end{array}$ & $\begin{array}{l}0.044^{*} \\
(0.024)\end{array}$ & $\begin{array}{c}0.104 * * * \\
(0.029)\end{array}$ & $\begin{array}{c}0.017 \\
(0.039)\end{array}$ \\
\hline$\triangle$ Leverage & & $\begin{array}{c}-0.024 * * * \\
(0.008)\end{array}$ & $\begin{array}{c}-0.024 * * * \\
(0.008)\end{array}$ & $\begin{array}{l}-0.015 \\
(0.017)\end{array}$ & $\begin{array}{l}-0.027 \\
(0.016)\end{array}$ & $\begin{array}{c}-0.083 * \\
(0.041)\end{array}$ & $\begin{array}{l}-0.083^{*} \\
(0.041)\end{array}$ & $\begin{array}{l}-0.048 \\
(0.067)\end{array}$ & $\begin{array}{l}-0.122 \\
(0.078)\end{array}$ & $\begin{array}{c}-0.079 * * * \\
(0.026)\end{array}$ & $\begin{array}{c}-0.079 * * * \\
(0.026)\end{array}$ & $\begin{array}{c}-0.102 * * * \\
(0.033)\end{array}$ & $\begin{array}{c}-0.077 * * \\
(0.026)\end{array}$ \\
\hline$\triangle$ Loss & & $\begin{array}{c}0.001 \\
(0.003)\end{array}$ & $\begin{array}{c}0.001 \\
(0.003)\end{array}$ & $\begin{array}{l}0.003 \\
(0.005)\end{array}$ & $\begin{array}{c}0.002 \\
(0.006)\end{array}$ & $\begin{array}{l}0.008 \\
(0.009)\end{array}$ & $\begin{array}{l}0.008 \\
(0.009)\end{array}$ & $\begin{array}{c}0.011 \\
(0.015)\end{array}$ & $\begin{array}{c}0.011 \\
(0.015)\end{array}$ & $\begin{array}{l}-0.002 \\
(0.005)\end{array}$ & $\begin{array}{l}-0.002 \\
(0.005)\end{array}$ & $\begin{array}{l}-0.010 \\
(0.012)\end{array}$ & $\begin{array}{c}0.002 \\
(0.005)\end{array}$ \\
\hline$\Delta$ Foreign Income & & $\begin{array}{c}0.045 \\
(0.092)\end{array}$ & $\begin{array}{c}0.046 \\
(0.092)\end{array}$ & $\begin{array}{l}-0.116 \\
(0.086)\end{array}$ & $\begin{array}{c}0.116 \\
(0.161)\end{array}$ & $\begin{array}{c}0.246 \\
(0.359)\end{array}$ & $\begin{array}{c}0.248 \\
(0.358)\end{array}$ & $\begin{array}{l}-0.484^{*} \\
(0.231)\end{array}$ & $\begin{array}{c}0.559 \\
(0.615)\end{array}$ & $\begin{array}{l}-0.080 \\
(0.079)\end{array}$ & $\begin{array}{l}-0.077 \\
(0.079)\end{array}$ & $\begin{array}{l}-0.004 \\
(0.103)\end{array}$ & $\begin{array}{l}-0.073 \\
(0.119)\end{array}$ \\
\hline$\triangle M T B$ & & $\begin{array}{c}0.001 * * \\
(0.000)\end{array}$ & $\begin{array}{c}0.001 * * \\
(0.000)\end{array}$ & $\begin{array}{c}0.001 \\
(0.001)\end{array}$ & $\begin{array}{c}0.001 \\
(0.000)\end{array}$ & $\begin{array}{c}0.007 * * * \\
(0.002)\end{array}$ & $\begin{array}{c}0.007 * * * \\
(0.002)\end{array}$ & $\begin{array}{c}0.003 \\
(0.003)\end{array}$ & $\begin{array}{c}0.008 * * \\
(0.003)\end{array}$ & $\begin{array}{c}0.001 \\
(0.001)\end{array}$ & $\begin{array}{c}0.001 \\
(0.001)\end{array}$ & $\begin{array}{c}0.001 \\
(0.002)\end{array}$ & $\begin{array}{c}0.002 \\
(0.001)\end{array}$ \\
\hline$\triangle A g e$ & & $\begin{array}{c}-0.004 \\
(0.003)\end{array}$ & $\begin{array}{l}-0.004 \\
(0.003)\end{array}$ & $\begin{array}{c}0.013 \\
(0.009)\end{array}$ & $\begin{array}{c}0.002 \\
(0.008)\end{array}$ & $\begin{array}{c}-0.012 \\
(0.010)\end{array}$ & $\begin{array}{l}-0.011 \\
(0.011)\end{array}$ & $\begin{array}{c}0.057 \\
(0.036)\end{array}$ & $\begin{array}{l}-0.019 \\
(0.027)\end{array}$ & $\begin{array}{c}0.057 * * \\
(0.025)\end{array}$ & $\begin{array}{c}0.058^{* *} \\
(0.025)\end{array}$ & $\begin{array}{c}0.057 \\
(0.042)\end{array}$ & $\begin{array}{c}0.067 \\
(0.044)\end{array}$ \\
\hline$\triangle$ Analyst Follow. & & $\begin{array}{l}-0.001 \\
(0.001)\end{array}$ & $\begin{array}{l}-0.001 \\
(0.001)\end{array}$ & $\begin{array}{l}-0.001 \\
(0.003)\end{array}$ & $\begin{array}{l}-0.000 \\
(0.003)\end{array}$ & $\begin{array}{l}-0.001 \\
(0.005)\end{array}$ & $\begin{array}{l}-0.000 \\
(0.005)\end{array}$ & $\begin{array}{l}-0.001 \\
(0.011)\end{array}$ & $\begin{array}{c}0.002 \\
(0.010)\end{array}$ & $\begin{array}{l}-0.000 \\
(0.003)\end{array}$ & $\begin{array}{l}-0.000 \\
(0.003)\end{array}$ & $\begin{array}{l}0.006^{*} \\
(0.004)\end{array}$ & $\begin{array}{l}-0.001 \\
(0.006)\end{array}$ \\
\hline$\triangle$ Geo. Complex. & & $\begin{array}{l}-0.005 \\
(0.004)\end{array}$ & $\begin{array}{l}-0.005 \\
(0.004)\end{array}$ & $\begin{array}{c}0.015 \\
(0.012)\end{array}$ & $\begin{array}{c}0.008 \\
(0.011)\end{array}$ & $\begin{array}{c}-0.032 * * \\
(0.014)\end{array}$ & $\begin{array}{c}-0.032 * * \\
(0.014)\end{array}$ & $\begin{array}{c}0.029 \\
(0.036)\end{array}$ & $\begin{array}{l}-0.005 \\
(0.036)\end{array}$ & $\begin{array}{c}0.014 \\
(0.010)\end{array}$ & $\begin{array}{c}0.014 \\
(0.011)\end{array}$ & $\begin{array}{c}0.051 * * \\
(0.023)\end{array}$ & $\begin{array}{c}0.026 \\
(0.018)\end{array}$ \\
\hline$\triangle$ Std Dev. Sales & & $\begin{array}{l}-0.007 \\
(0.011)\end{array}$ & $\begin{array}{l}-0.007 \\
(0.011)\end{array}$ & $\begin{array}{c}0.006 \\
(0.021)\end{array}$ & $\begin{array}{l}-0.003 \\
(0.023)\end{array}$ & $\begin{array}{l}-0.011 \\
(0.049)\end{array}$ & $\begin{array}{l}-0.011 \\
(0.049)\end{array}$ & $\begin{array}{c}0.066 \\
(0.059)\end{array}$ & $\begin{array}{c}0.022 \\
(0.106)\end{array}$ & $\begin{array}{c}0.007 \\
(0.038)\end{array}$ & $\begin{array}{c}0.006 \\
(0.037)\end{array}$ & $\begin{array}{l}-0.035 \\
(0.056)\end{array}$ & $\begin{array}{c}-0.073 * * * \\
(0.014)\end{array}$ \\
\hline$\triangle$ Restructure & & $\begin{array}{c}-0.006^{* * * *} \\
(0.002)\end{array}$ & $\begin{array}{c}-0.006^{* * * *} \\
(0.002)\end{array}$ & $\begin{array}{l}-0.002 \\
(0.004)\end{array}$ & $\begin{array}{c}-0.010^{* * * *} \\
(0.002)\end{array}$ & $\begin{array}{c}-0.019 * * \\
(0.007)\end{array}$ & $\begin{array}{c}-0.019 * * \\
(0.007)\end{array}$ & $\begin{array}{c}0.005 \\
(0.016)\end{array}$ & $\begin{array}{c}-0.034 * * * \\
(0.007)\end{array}$ & $\begin{array}{l}-0.008 \\
(0.006)\end{array}$ & $\begin{array}{l}-0.008 \\
(0.006)\end{array}$ & $\begin{array}{l}-0.004 \\
(0.010)\end{array}$ & $\begin{array}{l}-0.007 \\
(0.005)\end{array}$ \\
\hline$\Delta$ Instit. Owner. & & $\begin{array}{c}0.007 \\
(0.008)\end{array}$ & $\begin{array}{c}0.007 \\
(0.008)\end{array}$ & $\begin{array}{c}-0.004 \\
(0.018)\end{array}$ & $\begin{array}{l}-0.014 \\
(0.014)\end{array}$ & $\begin{array}{c}0.040 \\
(0.040)\end{array}$ & $\begin{array}{c}0.040 \\
(0.040)\end{array}$ & $\begin{array}{c}0.025 \\
(0.094)\end{array}$ & $\begin{array}{c}-0.032 \\
(0.071)\end{array}$ & $\begin{array}{c}0.031 \\
(0.019)\end{array}$ & $\begin{array}{c}0.031 \\
(0.018)\end{array}$ & $\begin{array}{c}0.028 \\
(0.056)\end{array}$ & $\begin{array}{c}0.028 \\
(0.025)\end{array}$ \\
\hline$\triangle I \_R O A$ & & $\begin{array}{c}0.006 \\
(0.033)\end{array}$ & $\begin{array}{c}0.004 \\
(0.033)\end{array}$ & $\begin{array}{c}0.131 * * \\
(0.056)\end{array}$ & $\begin{array}{l}-0.041 \\
(0.074)\end{array}$ & $\begin{array}{c}0.017 \\
(0.160)\end{array}$ & $\begin{array}{c}0.016 \\
(0.159)\end{array}$ & $\begin{array}{c}0.588 * * \\
(0.236)\end{array}$ & $\begin{array}{l}-0.104 \\
(0.332)\end{array}$ & $\begin{array}{l}-0.017 \\
(0.060)\end{array}$ & $\begin{array}{l}-0.022 \\
(0.059)\end{array}$ & $\begin{array}{c}0.217 * * \\
(0.075)\end{array}$ & $\begin{array}{l}-0.083 \\
(0.070)\end{array}$ \\
\hline$\Delta S D \_R e t$ & & $\begin{array}{c}-0.121 * * * \\
(0.030)\end{array}$ & $\begin{array}{c}-0.121 * * * \\
(0.030)\end{array}$ & $\begin{array}{l}-0.040 \\
(0.044)\end{array}$ & $\begin{array}{c}-0.207 * * \\
(0.061)\end{array}$ & $\begin{array}{c}-0.535 * * * \\
(0.143)\end{array}$ & $\begin{array}{c}-0.536^{* * * *} \\
(0.143)\end{array}$ & $\begin{array}{l}-0.106 \\
(0.186)\end{array}$ & $\begin{array}{c}-0.885 * * * \\
(0.228)\end{array}$ & $\begin{array}{c}-0.407 * * * \\
(0.061)\end{array}$ & $\begin{array}{c}-0.407 * * * \\
(0.061)\end{array}$ & $\begin{array}{c}-0.542 * * * \\
(0.052)\end{array}$ & $\begin{array}{c}-0.470 * * * \\
(0.113)\end{array}$ \\
\hline$\triangle$ Std Dev. PTBI & & $\begin{array}{c}0.108 * * \\
(0.042)\end{array}$ & $\begin{array}{c}0.108 * * \\
(0.042) \\
\end{array}$ & $\begin{array}{l}0.108^{*} \\
(0.061)\end{array}$ & $\begin{array}{c}0.178 \\
(0.096)\end{array}$ & $\begin{array}{c}0.409 * * * \\
(0.139) \\
\end{array}$ & $\begin{array}{c}0.408 * * * \\
(0.139)\end{array}$ & $\begin{array}{c}0.279 \\
(0.227)\end{array}$ & $\begin{array}{c}0.665 * * \\
(0.225) \\
\end{array}$ & $\begin{array}{c}-0.556^{* * * *} \\
(0.169)\end{array}$ & $\begin{array}{c}-0.557 * * * \\
(0.169)\end{array}$ & $\begin{array}{c}-0.050 \\
(0.277)\end{array}$ & $\begin{array}{c}-0.297 * * \\
(0.096)\end{array}$ \\
\hline Observations & & 15,421 & 15,421 & 2,780 & 7,056 & 11,838 & 11,838 & 2,431 & 6,310 & 15,355 & 15,355 & 2,776 & 7,051 \\
\hline Adj. R-squared & & 0.093 & 0.093 & 0.136 & 0.131 & 0.111 & 0.111 & 0.126 & 0.135 & 0.348 & 0.348 & 0.313 & 0.336 \\
\hline Ind. $\times$ Year FE & & Yes & Yes & Yes & Yes & Yes & Yes & Yes & Yes & Yes & Yes & Yes & Yes \\
\hline Firm Cluster & & Yes & Yes & Yes & Yes & Yes & Yes & Yes & Yes & Yes & Yes & Yes & Yes \\
\hline
\end{tabular}


Note: This table presents regression results for the tests that examine the association between IIQ and EIQ. Panel A, columns 1 and 2 (3 and 4 ) [5 and 6] report coefficients for an OLS regressions based on Equation (1) for EIQ_Error (EIQ_Disp) [EIQ_IDVOL]. Panel B uses the following changes model specification:

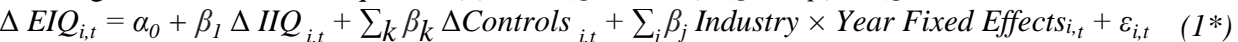

where $\Delta$ is the first-difference operator and the firm-level control variables are measured as of $t-1$. The variable specifications are the same as in the Equations (1). Panel B, columns 1 to 4 (5 to 8) [9 to 12] report coefficients for changes model regressions based on Equation (1) for EIQ_Error (EIQ_Disp) [EIQ_IDVOL].EIQ_Error is the average of absolute analysts' forecast errors in the year in which Tax Risk is calculated, multiplied by (-1). EIQ_Disp is the average of the standard deviation of analysts' annual earnings forecasts in the year in which Tax Risk is calculated, multiplied by (-1). EIQ_IDVOL is the standard deviation of residuals from firm-specific regressions of daily returns on daily values of the Fama-French (1993) three factors plus the momentum factor (Carhartt 1997; Campbell and Taksler 2003) over years $t+1$ to $t+5$, multiplied by (-100). EIQ_Error and EIQ_Disp are winsorized at the 99th percentiles. All other continuous variables are winsorized at the 1st and 99th percentiles. All regressions in Panel A are estimated with industry and year fixed effects and in Panel B with industry $\times$ year-fixed effects. I report heteroscedasticity-robust standard errors clustered by firm in parentheses. I define variables in Appendix A. Statistical significance at the $10 \%, 5 \%$ and $1 \%$ level is denoted by $*$, **, and ***, respectively. I use one-tailed tests when a sign is predicted and twotailed otherwise. 